\title{
REGULATING LOBBYISTS IN NEW ZEALAND
}

\author{
BY
}

LIAM ALEXANDER WILLIAMS

\begin{abstract}
A thesis
submitted to the Victoria University of Wellington in fulfilment of the requirements for the degree of Master of Laws
\end{abstract}

Victoria University of Wellington

2014 


\section{Contents}

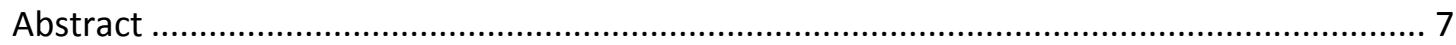

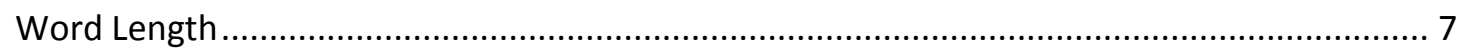

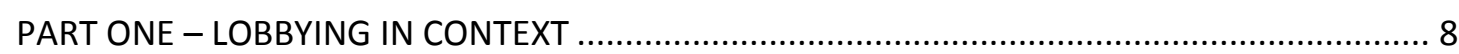

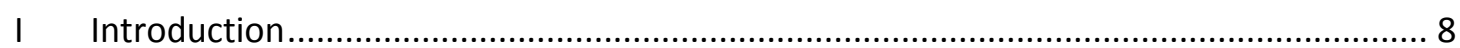

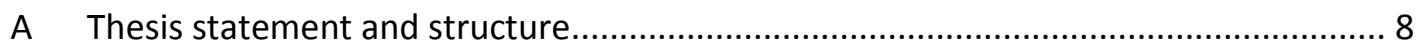

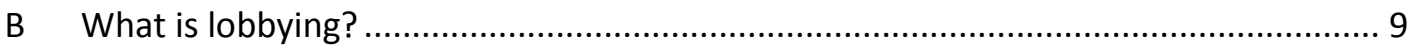

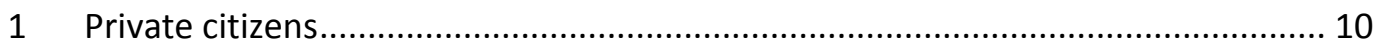

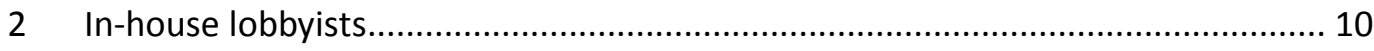

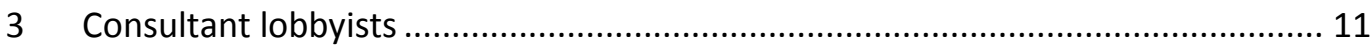

C The Lobbying Disclosure Bill in the international context....................................... 11

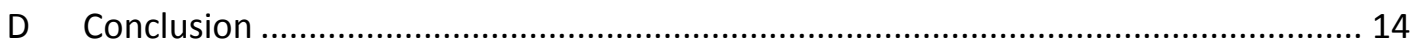

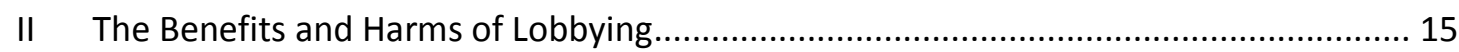

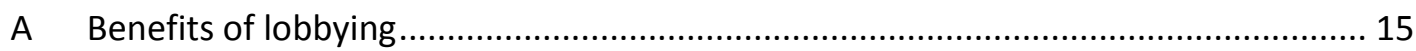

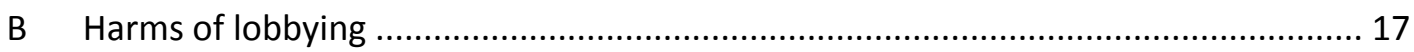

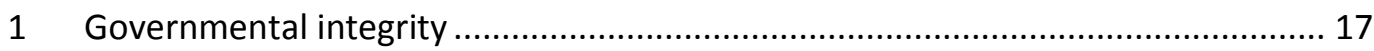

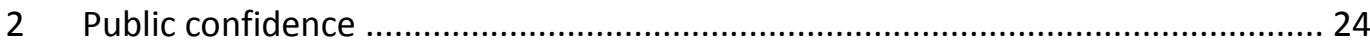

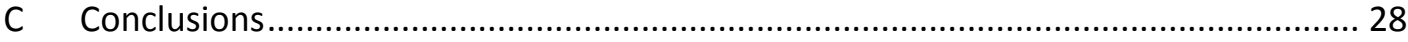

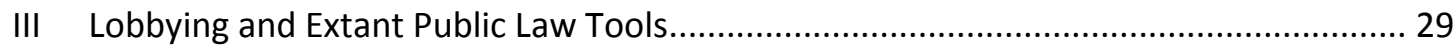

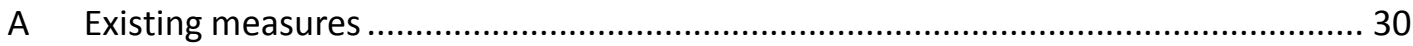

1 Crimes Act 1961 and corruption and bribery offences ......................................... 30

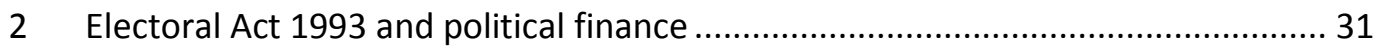

3 Standing Orders of the House of Representatives 2011 and gifts ......................... 37

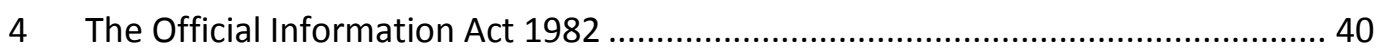

B Conclusion - A case for an additional public law tool? ............................................. 44

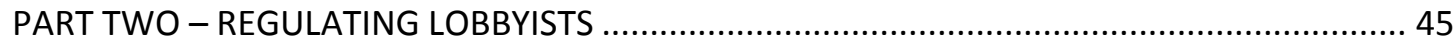

IV Registering Lobbyists and Recording Lobbying Activity .............................................. 45

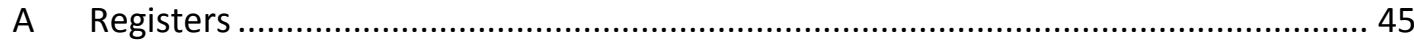

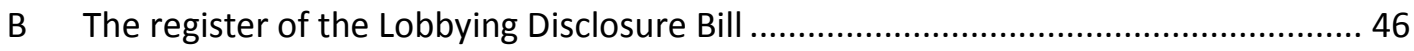

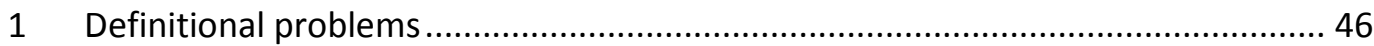

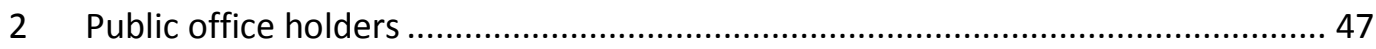

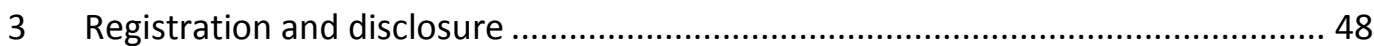

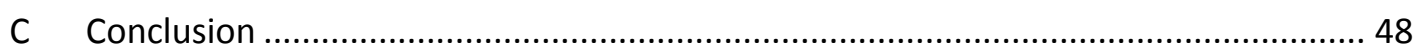

V Who Must Register? Defining "Lobbyists" and "Lobbying Activity" .............................. 49 
A Introduction ........................................................................................ 49

B Defining "lobbying" - International approaches at a glance .................................. 50

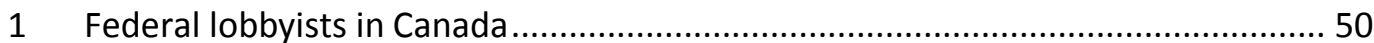

2 Federal lobbyists in the United States.......................................................... 52

3 Federal lobbyists in Australia .................................................................. 54

C Defining "lobbying" - What can we learn from other jurisdictions? ....................... 54

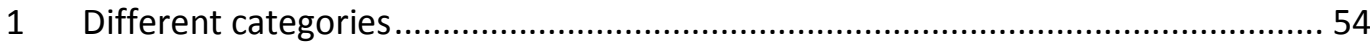

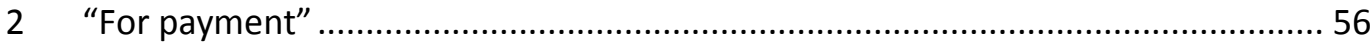

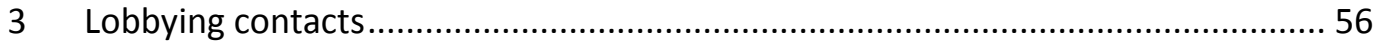

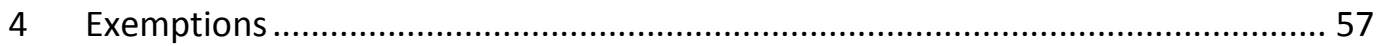

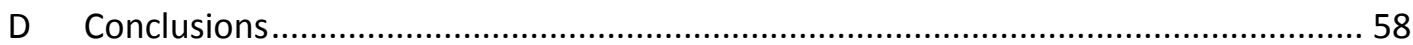

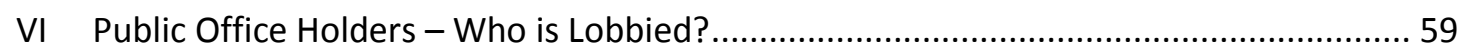

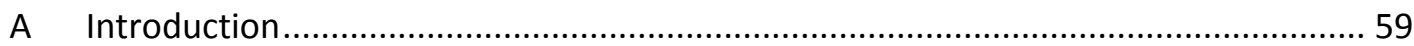

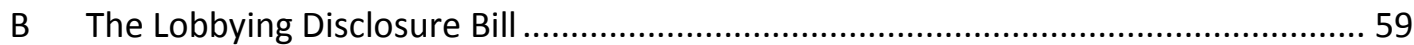

C Classifying public office holders - International approaches at a glance ................60

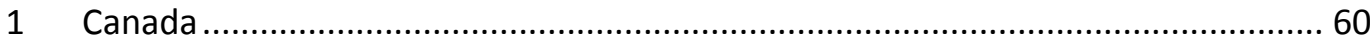

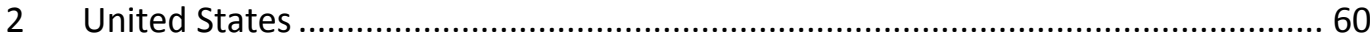

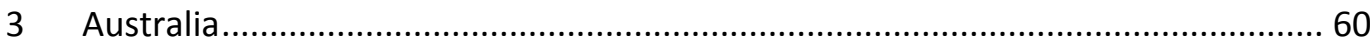

D Public office holders - What can we learn from other jurisdictions? ...................... 61

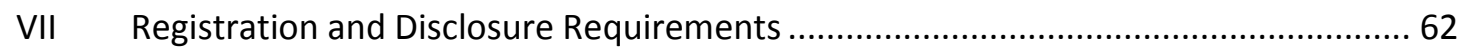

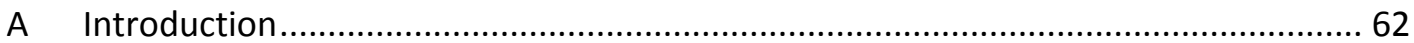

B Registration and disclosure requirements - International approaches at a glance ... 63

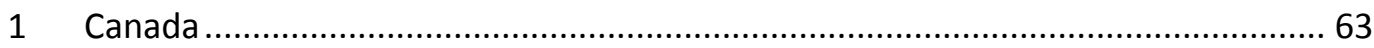

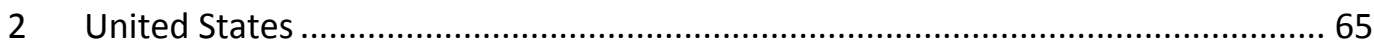

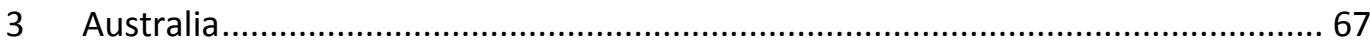

C Registration and disclosure - What can we learn from other jurisdictions? ............ 67

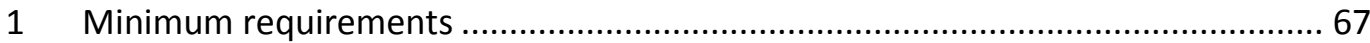

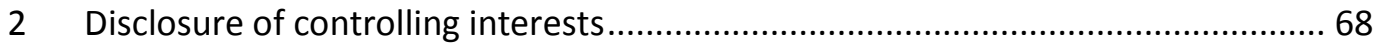

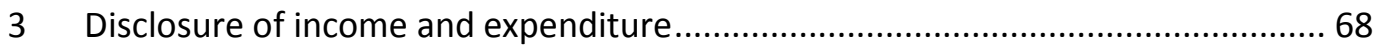

4 Disclosure of lobbyists who are ex-public office holders ..................................69

5 Disclosure of designated public office holder communications ............................ 70

D Suggested Provisions ................................................................................ 71

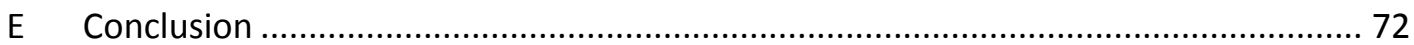

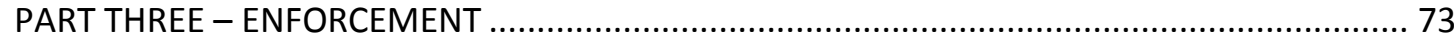




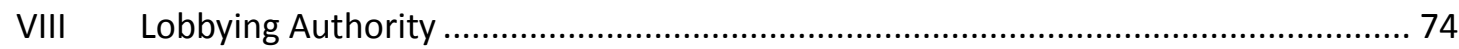

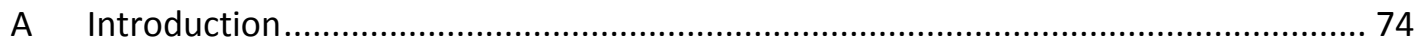

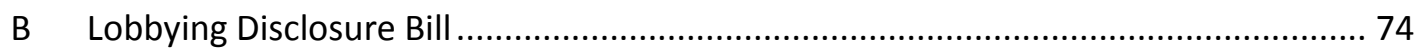

C Necessary characteristics of lobbying authorities ....................................................... 74

D Officers of Parliament as lobbying authority candidates ........................................... 75

1 The Officers of Parliament Committee................................................................... 75

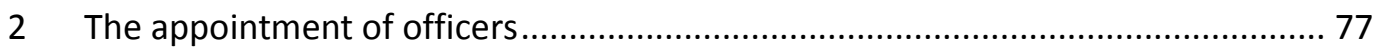

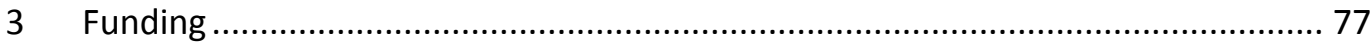

$4 \quad$ The independence of Offices of Parliament....................................................... 78

E Considering existing Offices of Parliament for a lobbying authority role ................... 78

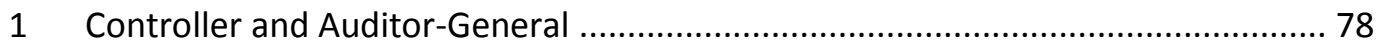

2 Parliamentary Commissioner for the Environment .............................................. 79

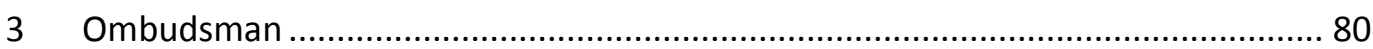

F Contemplating a Parliamentary Commissioner for Lobbying .................................. 80

IX Enforcement: Codes of Conduct and Criminal Sanctions............................................ 82

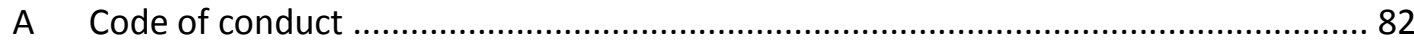

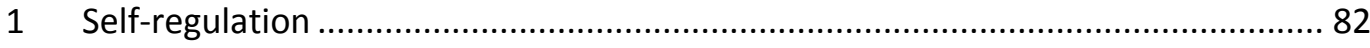

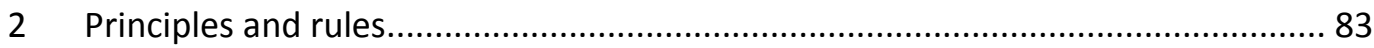

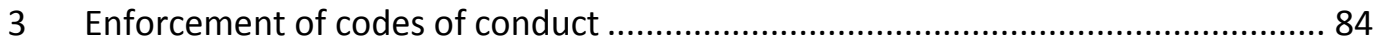

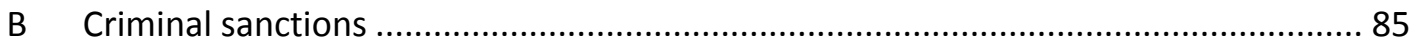

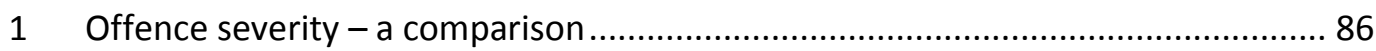

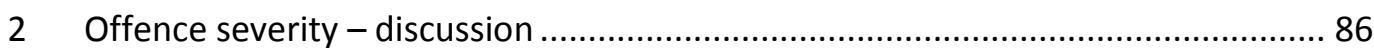

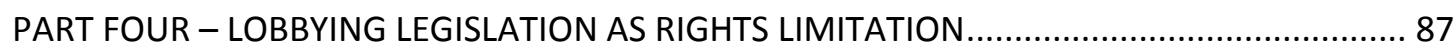

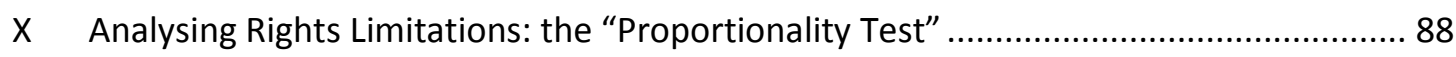

A Reconciling lobbying legislation with obligations under the New Zealand Bill of Rights Act 1990.

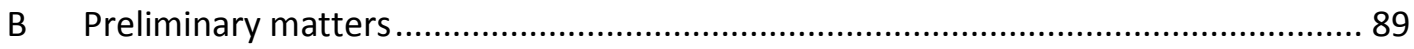

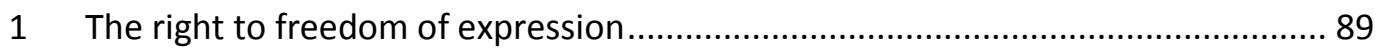

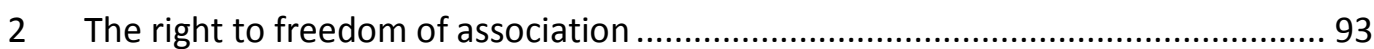

C Is the objective of the impugned provision of sufficient importance to warrant overriding a constitutionally protected right or freedom? ................................................. 94

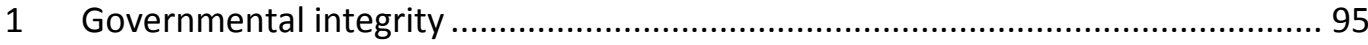

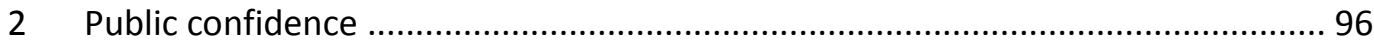

D The second part of Hansen - the proportionality test ................................................ 96 
1 Rational connection

2 Do the limitations impair the right or freedom in question as 'little as reasonably possible'?

3 Are the effects of the limitation of rights and freedoms proportional? ............... 101

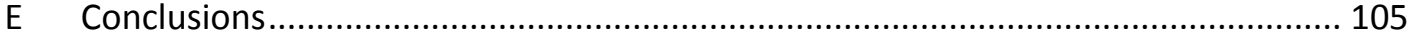

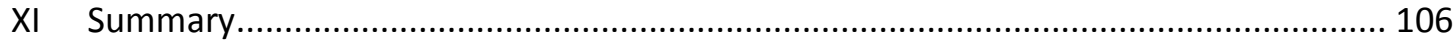

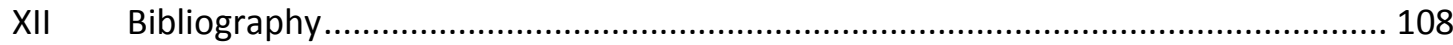

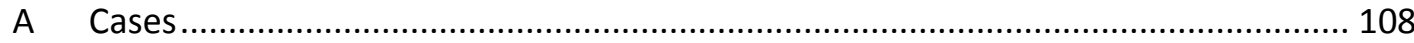

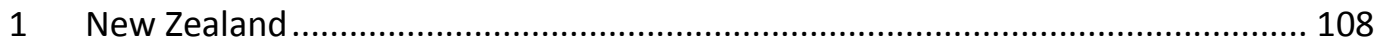

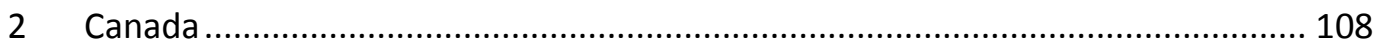

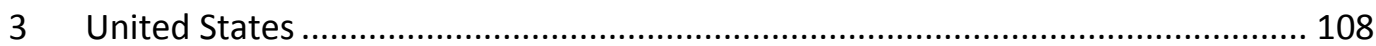

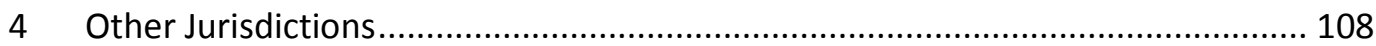

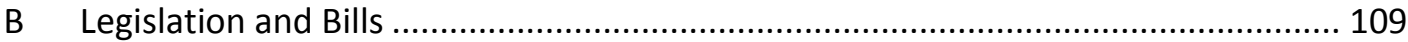

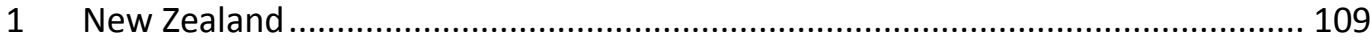

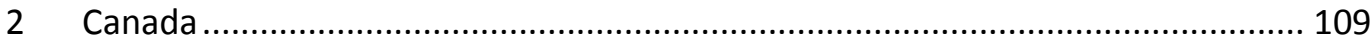

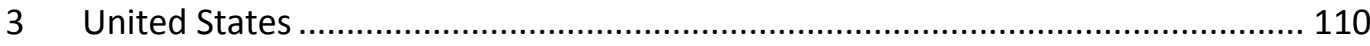

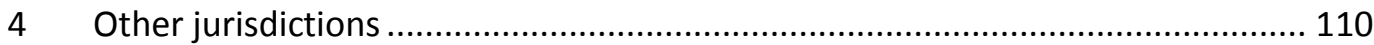

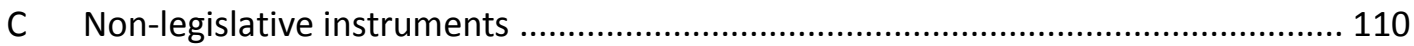

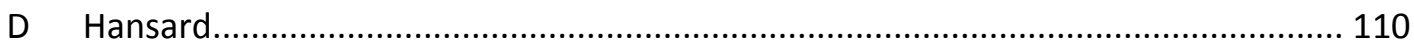

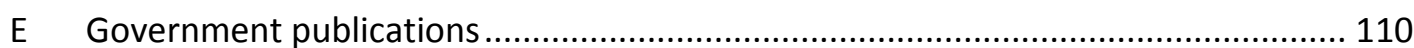

F Appendices to the Journal of the House of Representatives .................................. 111

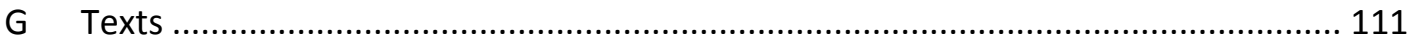

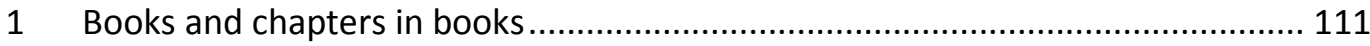

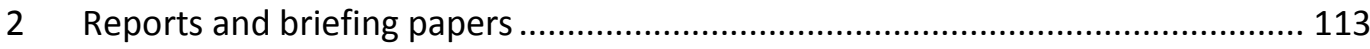

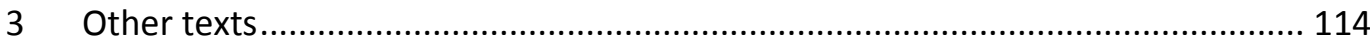

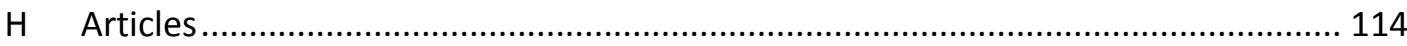

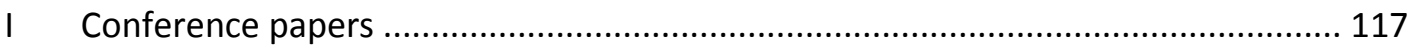

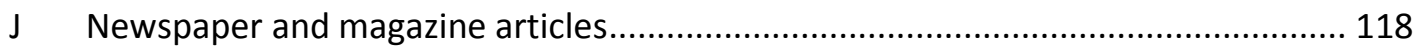

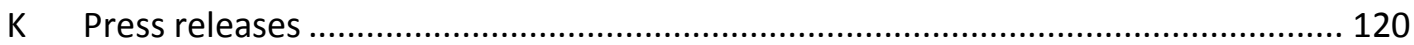

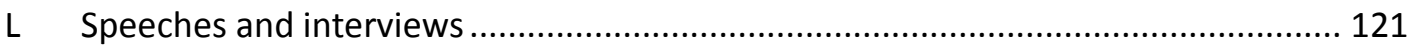

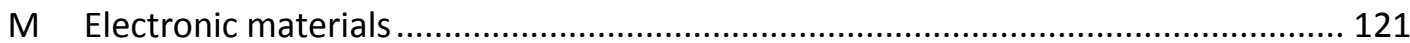

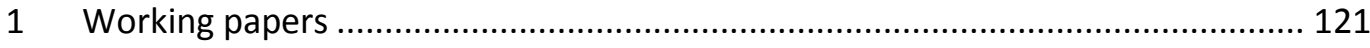

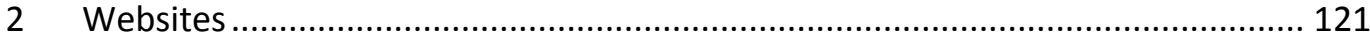

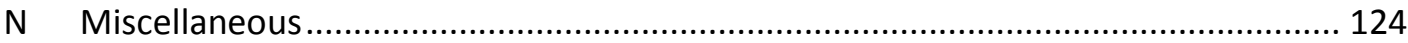




\section{Acknowledgements}

This paper would not have been possible without the support that I received from a number of people. I would first like to give my thanks and love to my family for inspiring me to pursue a higher education, and to endure the hardships that this path occasionally entails. In particular, I would like to recognise the encouragement I received from my mother and father.

Thanks are also due to my academic supervisor Professor Claudia Geiringer, who helped me to shape my work from the chaotic jumble from whence it came to the comprehensible argument that it now forms. In addition, University of Waikato Professor Margaret Wilson and investigative journalist Nicky Hager generously lent me their time and expertise to share their insights on lobbying activity in New Zealand, for which I am grateful. Finally, the mentoring support given to me by University of Waikato Senior Lecturer Juliet Chevalier-Watts was invaluable, and played a crucial role the eventual creation of this thesis. 


\begin{abstract}
Lobbying is a vital aspect of democratic governance and is for the most part beneficial to society. However, recent high-profile instances of lobbying activity in New Zealand have damaged governmental integrity and appear to have diminished public confidence in government decision-making processes. The Lobbying Disclosure Bill was introduced to the New Zealand Parliament in 2012 in the hope that transparency mechanisms could dissuade harmful lobbying without impeding ordinary activity.

The Bill was rejected at the select committee stage due to a number of drafting deficiencies. These shortcomings made the Bill difficult to implement, and imposed a disproportionate limit on a number of human rights. Despite these failings, it is both possible and desirable to regulate lobbying activity in New Zealand. Drawing from overseas experiences, this paper suggests modifications to the Lobbying Disclosure Bill which would discourage harmful lobbying while also mitigating the concerns raised by critics of the Bill.
\end{abstract}

\title{
Word Length
}

The text of this paper (excluding abstract, table of contents, footnotes and bibliography) comprises approximately 38,788 words. 


\section{PART ONE - LOBBYING IN CONTEXT}

\section{Introduction}

On 5 April 2012, the Lobbying Disclosure Bill ${ }^{1}$ was drawn from the New Zealand Parliamentary Ballot. Its provisions were taken, mostly verbatim, from its Canadian counterpart, the Lobbying Act $1985 .^{2}$ Its stated intention was to "bring a measure of transparency and public disclosure around the lobbying activity directed at members of Parliament and their staff, and in so doing to enhance trust in the integrity and impartiality of democracy and political decision making."3

The drafters of the Bill intended for it to establish a lobbyists' register, to which all paid lobbyists would be obliged to subscribe. Lobbyists would have been required to file regular returns with the Controller and Auditor-General, whose responsibility it would be to compile the information contained therein and make it available as part of the register on a publically-accessible website. Engaging in lobbying activity as an unregistered lobbyist could result in fines up to $\$ 10,000$ for an individual or $\$ 20,000$ for a company or organisation. ${ }^{4}$ The Auditor-General would have had the responsibility of ensuring that lobbyists comply with the provisions of the Bill via an augmentation of the office's existing investigatory powers under the Public Audit Act 2001. ${ }^{5}$ The Bill also would have required the Auditor-General to develop a Lobbyists' Code of Conduct, ${ }^{6}$ to which lobbyists would be required to adhere under threat of deregistration (and, presumably, a resultant loss of livelihood). ${ }^{7}$

The Bill received broad support on its first reading, but was ultimately rejected by the Government Administration Committee. The committee cited several concerns about the Bill. It was chiefly criticised for failing to adequately define who and what type of activities ought to be subject to its provisions. ${ }^{8}$

\section{A Thesis statement and structure}

The central contention of this paper is that it is both possible and desirable to enact legislation to effectively regulate lobbyists in New Zealand.

This contention is developed in this paper in the following manner. Firstly, it establishes that unregulated lobbying can be detrimental to governmental integrity and public confidence in governmental actors and decision-making processes. It demonstrates that lobbying legislation is justifiable and should be actively pursued by Parliament. Secondly, it suggests an approach to regulation that could discourage unethical lobbying, preserve and legitimise ethical lobbying activity and dramatically increase the amount of information available to the New Zealand public about who is conducting lobbying activity, and for what purpose. Thirdly, it argues that concerns about the impact of lobbying regulation on the rights to freedom of expression and

\footnotetext{
${ }^{1}$ The Lobbying Disclosure Bill 2012 (15-1) was a member's Bill introduced former Green Party MP Sue Kedgley and inherited by MP Holly Walker.

${ }^{2}$ Lobbying Act RSC 1985 c44; Lobbying Disclosure Bill 2012 (15-1) (explanatory note).

${ }^{3}$ Lobbying Disclosure Bill 2012 (15-1) (explanatory note).

${ }^{4}$ Lobbying Disclosure Bill 2012 (15-1), cl 19.

${ }^{5}$ Public Audit Act 2001, Part 4.

${ }^{6}$ Lobbying Disclosure Bill 2012 (15-1), cl 13.

${ }^{7}$ Lobbying Disclosure Bill 2012 (15-1), cl 16.

${ }^{8}$ Lobbying Disclosure Bill 2012 (15-1) (select committee report) at 3.
} 
association can be partially mitigated by clarity in drafting, and are otherwise demonstrably justifiable in a free and democratic society. Accordingly, this paper is broken into three Parts: Lobbying in Context, Regulating Lobbyists, and Lobbying Legislation as Rights Limitation.

This chapter explains the scope of lobbying legislation and contextualises the Lobbying Disclosure Bill in its international and domestic environment. Chapter II takes stock of the benefits and harms of lobbying activity, and Chapter III analyses the degree to which these harms are currently mitigated by existing measures in New Zealand.

Chapter IV introduces some of the key measures implemented in regimes where lobbyists are regulated, and compares them to the measures suggested in the Lobbying Disclosure Bill. Chapters V and VI assess the various approaches taken in other jurisdictions to define who should be captured by lobbying regulation. Chapter VII evaluates which regulatory burdens are most suitable to reduce lobbying harms in New Zealand. Chapters VIII and IX deal with matters of enforcement. The former is concerned with determining which government agency should be granted oversight in the event that regulating legislation is passed. The latter canvasses criminal and nonlegislative methods of compliance and makes suggestions for the New Zealand context.

Chapter $\mathrm{X}$ analyses the potential limits imposed by lobbying legislation on the rights to freedom of expression and association, and explains how these can be mitigated, and otherwise justified. Chapter XI surmises the way in which the Lobbying Disclosure Bill could be modified to meet the central contention of this paper.

What is lobbying?

Democracy is a story of competing interests in matters of governance. ${ }^{9}$ In modern, liberal democracies, the most recent chapter of democracy has been primarily concerned with the distribution of political influence; the settled position is in favour of universal suffrage. ${ }^{10}$ However, it would be naïve to believe that the political influence begins and ends at the ballot box. Once elected, government representatives have a duty to take stock of public opinion and respond appropriately during their time in office. To an extent, electoral and post-electoral phases have become blurred in many modern democracies, giving rise to a so-called "permanent campaign". ${ }^{11}$ This on-going participatory aspect of democracy is supplemented by a form of political activity which can be very broadly referred to as "lobbying".

The Encyclopædia Britannica defines lobbying as "any attempt by individuals or private interest groups to influence the decisions of government". ${ }^{2}$ This definition encompasses activity which has existed in structured political environments for thousands of years. For example, we know that lobbying was evident in the

\footnotetext{
${ }^{9}$ See generally David Held Models of Democracy (Stanford University Press, 2006) at 161.

${ }^{10}$ Universal suffrage is rarely universal in truth. Common exceptions include minors, the mentally disabled and, in some states, criminal offenders. See Liam Williams "Civil Death and Penal Populism in New Zealand” (2012) 20 Waikato L Rev 111.

${ }^{11}$ Dorie Apollonio, Bruce E Cain, Lee Drutman “Access and Lobbying: Looking Beyond the Corruption Paradigm" (2008) 36 Hastings Const LQ 13.

12 "Lobbying" (2013) Encyclopædia Britannica <http://www.britannica.com/EBchecked/topic/345407/lobbying>.
} 
administration of ancient Greece and Rome, ${ }^{13}$ and that later kings and queens met with petitioners to air their grievances and - if the applicant was successful - receive redress. It is thought that if "the barons had not lobbied King John, he would not have signed the Magna Carta at Runnymede". 14

While the activity might date back to the genesis of government, the origin of the use of the word "lobbying" to describe it is in an unsettled position. Some believe that it originated in Washington in the mid- $19^{\text {th }}$ Century, at the Willard InterContinental Hotel. There, President Ulysses S. Grant would meet with favour-seekers in the lobby, hence the development of the verb. ${ }^{15}$ This is highly unlikely, given that there are records which appear to show its use within the United States dating back to $1792,{ }^{16}$ and further still in the House of Commons in England. ${ }^{17}$

In modernity, "lobbying" is a term used to describe the participatory activities of a certain group of professionals who specialise in liaising with government representatives. Contemporary lobbyists take various forms, delineated either by the method of communication employed or by the nature of the relationship between the lobbyist and client concerned. To illustrate the diversity between the various actors in the modern lobbying environment, three main categories are described below. This list is by no means exhaustive and merely reflects one of the many ways in which lobbyists may be categorised.

\section{$1 \quad$ Private citizens}

The most modest lobbyist is the private constituent who undertakes to influence his or her political representative. This might occur for a plethora of reasons; for example, the owner of a small importing business might wish to raise concerns about excise taxes, or a mother might want to encourage an MP to change his or her position on maternity leave. These interactions are the lifeblood of democratic representation, ${ }^{18}$ helping to reduce disconnect sometimes experienced between the elected and their electors. They also allow representatives to be "grounded" in their constituencies, and thus aware of the concerns of the electorate.

\section{$2 \quad$ In-house lobbyists}

In-house lobbyists are those employees "whose duties include communicating with public office holders on behalf of an employer." ${ }^{19}$ These employers might

\footnotetext{
${ }^{13}$ Marjorie Jerrard "The Collegium Fullonum, Collegium Centonarium, and CATU: Ancient Collegia and Modern Trade Unions - A Comparison of the Roles of Industrial Organisations in their Respective Societies" (paper presented to Association of Industrial Relations Academics of Australia and New Zealand Conference, Wellington, 1998) at 2.

${ }^{14}$ Lionel Zetter Lobbying: The Art of Political Persuasion (1st ed, Harriman House, Hampshire, 2008) at 6 .

${ }^{15}$ Tom Avermaete and Anne Massey Hotel Lobbies and Lounges: The Architecture of Professional Hospitality (Routledge, 2012) at 112.

${ }^{16}$ Vincent R Johnson "Regulating Lobbyists: Law, Ethics, and Public Policy" (2006) 16 Cornell JL 1 at 11.

${ }^{17}$ Interview with Jessie Sheidlower, Editor-at-Large Oxford English Dictionary (Liane Hansen, A Lobbyist by any other name, National Public Radio, 22 January 2006) transcript provided by National Public Radio (Washington).

${ }^{18}$ Pippa Norris “Democratic Phoenix: Agencies, Repertoires and Targets of Political Activism" (paper presented to the Annual American Political Science Association, Boston, 29 August 2002).

${ }^{19}$ OECD Lobbyists, Governments and Public Trust, Volume 1: Increasing Transparency Through Legislation (OECD Publishing, 2009) at 50.
} 
conceivably include organisations, corporations, churches, not-for-profits or universities. The in-house lobbyist generally has some political perspicacity and the ability to convey messages between his or her employer and the appropriate public official. In New Zealand, an in-house lobbyist might be expected to make submissions to select committees or contact public officials to discuss matters relevant to his or her employer. Most significantly, these lobbyists act solely on behalf of their employers when conducting lobbying activity.

An in-house lobbyist can take a variety of forms, and work for a variety of employers. Used generally, the term could encapsulate both the government relations team at Vodafone New Zealand and a part-time employee of the Kidney Kids charity who occasionally emails public officials or makes select committee submissions. What might reasonably apply to the former might not be expected of the latter, particularly in light of relative influence and resources. ${ }^{20}$ This has led to a number of legislative clarifications (between in-house lobbyists employed by corporations and not-forprofits, for example $)^{21}$ in a range of jurisdictions.

\section{$3 \quad$ Consultant lobbyists}

Those persons who conduct lobbying activity on behalf of multiple different thirdparties fall into the consultant lobbyist category. A range of professions fall within this definition. Dedicated government relations consultants and public affairs specialists such as Saunder Unsworth, Glass Tower, Exceltium and Porter Novelli are one target of this description. Public law firms, such as Chen Palmer (Australasia's first), Simpsons Grierson and Buddle Finlay would also be captured by such a definition.

\section{The Lobbying Disclosure Bill in the international context}

For various reasons, lobbying has become associated with influence trading and corruption in the public eye. At a fundamental level, this is because lobbying can provide interest groups with a degree of political influence unavailable to ordinary citizens. As the old argument goes, power in the political world is a zero-sum game. ${ }^{22}$ An increase in the influence wielded by the lobbyist directly undermines the ability of other governed parties to affect change. It is natural, then, for the public to resent lobbyists on the basis that they represent a legitimised form of disenfranchisement. While this may indeed be at the heart of the negative conceptions held about lobbyists, there are a host of other reasons why the practice has come to be held in such low regard.

A number of prominent political scientists have released findings which seem to suggest that organised interest groups create irrational or inefficient policies. The rationale claims "the universal pursuit of political advantage leads to... perverse results... all of which are designed to redistribute rents from unorganized groups (consumers and taxpayers) to organised interests." 23 This is known as Olson's

\footnotetext{
${ }^{20}$ See Chapter 5 for a detailed discussion about the use of different requirements for different classes of lobbyists.

${ }^{21}$ Lobbying Act RSC 1985 c44, ss5, 7.

${ }^{22}$ James H Read "Is Power Zero-Sum or Variable-Sum? Old Arguments and New Beginnings" (paper presented to the Annual American Political Science Association, California, 2 September 2011).

${ }^{23}$ William C Mitchell \& Michael C Munger "Economic Models of Interest Groups: An Introductory Survey" (1991) 35 AJPS 512 at 517.
} 
"institutional sclerosis", and entails the prediction that "special interest groups will accumulate over time in stable societies and eventually reduce the economic efficiency of the economy in which they operate." 24

This negative conception is reinforced by lobbying scandals which regularly occur throughout the world. These serve to reinforce the worst possible characterisations of lobbyists. Perhaps the most well-known recent instance of this was the United States' Jack Abramoff scandal, which was exposed by the Washington Post in $2006 .{ }^{25}$ As a prolific Republican lobbyist, Jack Abramoff used his considerable wealth to bribe public officials and defraud his clients. He was eventually sentenced to five years and ten months in prison, and several of his accomplices have been convicted. Six lawmakers are currently under investigation by the FBI in relation to the scandal, and two members of Congress have relinquished their roles. While the scale of this operation may be unprecedented, its theme is not. In the most recent scandal to wrack the United Kingdom House of Commons, MP Patrick Mercer was exposed by journalists who posed as lobbyists as accepting significant sums of money in return for tabling parliamentary questions on their behalf. ${ }^{26}$

Lobbyists have also been criticised for allegedly contributing towards the onset of the 2007-2008 Global Financial Crisis. ${ }^{27}$ In 2011, three IMF economists from the National Bureau of Economic Research released a working paper which provides information which appears to draw a connection between bank lobbyists, poor lending practices and bailouts. ${ }^{28}$

These types of scandals have ensured that lobbying has come to symbolise the way in which money can buy power in matters political. The facilitator of this arrangement the lobbyist - has borne the brunt of the public ire that has arisen as a result. The "ideological baggage" 29 that is attached to the practice gives it "roughly the same cachet as... 'deadbeat dad'." ${ }^{30}$ It has become "an unsavoury part of the political process." ${ }^{31}$ A particularly venomous caricaturisation of lobbyists was pronounced by reporter Emily Briggs in 1869, “...winding in and out through the long, devious basement passage, crawling through the corridors, trailing its slimy length from gallery to committee room, at last it lies stretched at full length on the floor of

\footnotetext{
${ }^{24}$ Jac C Heckelman "Explaining the Rain: The Rise and Fall of Nations after 25 Years" (2007) 74 Southern Econ J 18 at 19.

${ }^{25}$ Susan Schmidt, James V Grimaldi and R Jeffrey Smith "Investigating Abramoff - Special Report" (2005) The Washington Post <http://www.washingtonpost.com/wpdyn/content/linkset/2005/06/22/LI2005062200936.html>.

26 "Lobbying Scandal Q\&A: What it all means" The Telegraph (online ed, London, 01 June 2013).

${ }^{27}$ Nicole Gillespie, Robert Hurley, Graham Dietz and Reinhard Bachmann "Restoring Institutional Trust after the Global Financial Crisis" in Roderick M Kramer and Todd L Pittinsky (eds) Restoring Trust in Organizations and Leaders: Enduring Challenges and Emerging Answers (Oxford University Press, 2012) at 196; Daniel Kaufmann "Corruption and the Global Financial Crisis" (2009) Forbes < http://www.forbes.com/2009/01/27/corruption-financial-crisis-business-corruption.html>.

${ }^{28}$ Deniz Igan, Prachi Mishra and Thierry Tressel "A Fistful of Dollars: Lobbying and the Financial Crisis" (May 2011) The National Bureau of Economic Research <http://www.nber.org/papers/w17076>.

${ }^{29}$ Andrew P Thomas "Easing the Pressure in Pressure Groups: Toward a Constitutional Right to Lobby" (1993) 16 Harv JL \& Pub Pol 149.

${ }^{30}$ David Segal "Main Street America Has Advocates Aplenty: On the Hill, Lobbyists for All" Washington Post, (A1, Washington DC, 10 July 1995).

${ }^{31}$ Meredith A Capps "Gouging the Government: Why a Federal Contingency Fee Lobbying Prohibition is Consistent with First Amendment Freedoms” (2005) 58 Vand L Rev 1885 at 1886.
} 
Congress - this dazzling reptile, this huge, scaly serpent of the lobby." ${ }^{32}$ Similar renditions abound in popular fiction, ${ }^{33}$ prominent opinions, ${ }^{34}$ news media ${ }^{35}$ and even academic publications. ${ }^{36}$ This perception has implications for the effective and fair drafting of legislation to regulate lobbyists.

In addition to negatively affecting the way that society perceives lobbyists, lobbying scandals provide democratic incentives to law-makers to introduce legislation to regulate the activity. The number of states implementing lobbying regulations has tripled within the last decade. ${ }^{37}$ Many of these states have struggled with lobbying scandals of their own. ${ }^{38}$ A strong public and political response to these scandals has encouraged reform. ${ }^{39}$

In 2009, the OECD produced two reports in response to what it identified as "impressive mobilisation of private resources" 40 which are devoted to lobbying activity in democracies throughout its constituent states. These reports represent what is probably the most comprehensive international study ever conducted with respect to lobbying activity. It found that many societies believed that lobbying "gives special advantages to 'vocal vested interests' and that negotiations carried on behind closed doors can override the "wishes of the whole community' in public decision making." 41 Not only does lobbying appear to unfairly distribute political power, but it also seems that the way in which this power is exercised may conflict with public interest. ${ }^{42}$ Three years later, the Lobbying Disclosure Bill was drawn from the New Zealand Parliamentary Ballot. It drew heavy inspiration from the recommendations of the Public Governance Committee of the OECD. ${ }^{43}$

In addition to overseas trends and the recommendations of the OECD, New Zealand law-makers have domestic incentives to regulate. It is difficult to take stock of the

\footnotetext{
32 “'Lobbyists' September 28, 1987” (2005) United States Senate

<http://www.senate.gov/legislative/common/briefing/Byrd_History_Lobbying.htm>.

${ }^{33}$ A recent example of this is the Hollywood blockbuster film Thank You for Smoking (2005).

${ }^{34}$ Barack Obama, President of the United States "Ethics and Lobbying Reform" (Lobbying Reform Summit, Washington DC, 26 January 2006).

35 "Editorial: Undue Influence" The New Zealand Listener (online ed, Auckland, 28 November 2013).

${ }^{36}$ Mancur Olson The Rise and Decline of Nations: Economic Growth, Stagflation, and Social Rigidities (Yale University Press, 2008) at 69.

37 "Fighting Corruption in the Public Sector" (2013) OECD: Better Policies for Better Lives

<www.oecd.org/gov/ethics/lobbying>.

${ }^{38}$ The Conservative MP for Newark has resigned in the latest of a string of lobbying scandals in the United Kingdom. See Claire Newell and Holly Watt "Patrick Mercer MP resigns over lobbying scandal" The Telegraph (online ed, London, 31 May 2013); Caroline Lucas "Influence on MPs must be exposed and regulated" The Guardian (online ed, London, 22 July 2013). A recent EU lobbying scandal has also embroiled officials from Austria, Romania, Slovenia and Spain. See David Hannan "The MEP lobbying scandal is worse than anything at Westminster, but it will be largely ignored" The Telegraph (online ed, London, 20 March 2011).

${ }^{39}$ For example, the United Kingdom has passed the Transparency of Lobbying, Non-party

Campaigning and Trade Union Administration Act 2014 (UK), and the European Union has begun to strengthen its existing framework with the Interinstitutional Agreement 2291/2010 on a Common Transparency Register [2009] OJ C 271 E.

${ }^{40}$ OECD Lobbyists, Governments and Public Trust, Volume 1: Increasing Transparency Through Legislation (OECD Publishing, 2009) at 5.

${ }^{41}$ OECD Lobbyists, Governments and Public Trust, Volume 1: Increasing Transparency Through Legislation (OECD Publishing, 2009) at 11.

42 Stephen Barley "Corporations, Democracy and the Public Good” (2007) 16 J Manage Inq 201 at 210.

${ }^{43}$ Lobbying Disclosure Bill 2012 (15-1) (explanatory note).
} 
state of lobbying practices in New Zealand, given that the industry is currently unregulated and thus prone to secrecy. Despite this, several instances of lobbying have hit headlines for various degrees of underhandedness over the past five years. ${ }^{44}$ This publicity may have been responsible for unanimous support that the Lobbying Disclosure Bill received in its first reading.

A closer analysis of this support makes it abundantly clear that it was tenuous at best; each MP who spoke on the Bill made it plain that the Bill would lose support if it was not significantly amended at select committee. ${ }^{45}$ The Government Administration Committee granted a six month extension to allow MP Holly Walker to amend her Bill. Unfortunately, the results were found wanting and the committee eventually recommended that the Bill not pass into law. Instead, it advised Parliament to develop guidelines for parliamentarians on how to handle lobbying communications, and that governments include details to identify those lobbyists consulted in the explanatory notes of parliamentary bills. ${ }^{46}$

\section{Conclusion}

The Bill was not rejected because its intentions were unworthy. Instead, it seems that the method by which it aimed to achieve its aims were found wanting. Unfortunately, the recommendations made by the select committee are comparatively weak, and will likely do little to assuage fears of unethical lobbying activity in New Zealand. The following two chapters explain why lobbying activity in New Zealand requires regulation, and that current public law tools are not up to the task.

\footnotetext{
${ }^{44}$ A number of these instances are analysed in Chapter II.

45 (25 July 2012) 682 NZPD at 3962, 3964 and 3966.

${ }^{46}$ Lobbying Disclosure Bill 2012 (15-1) (select committee report) at 5.
} 


\section{The Benefits and Harms of Lobbying}

In its report on the Lobbying Disclosure Bill, the Government Administration Committee advised that the Bill was inappropriate for the New Zealand context. ${ }^{47}$ The following day, Committee Chair MP Ruth Dyson minimised the need for the introduction of lobbying legislation, because "New Zealand is a village. We know who the lobbyists are, and what they're going to talk to us about." ${ }^{\text {" }}$ This chapter assesses the validity of this contention in light of the relative benefits and harms that lobbying has provided in New Zealand.

In order to progress the debate surrounding lobbying legislation in New Zealand, it is first necessary to assess the effects of lobbying activity. Such law is primarily drafted to address two issues: the tendency for lobbying to damage the integrity of government processes, and the related propensity for lobbying to decrease public confidence in the integrity of governmental institutions and public officials. ${ }^{49}$ These issues formed the basis of the OECD Principles for Transparency and Integrity of Lobbying, which was adopted by member countries in 2010 and prompted the introduction of the Lobbying Disclosure Bill. It is fair to say that the presumption of harm forms the absolute bedrock principle for lobbying legislation. It is therefore absolutely crucial to establish that the harm - or the potential for it to eventuate exists in truth before movements are made to legislate.

This chapter answers a number of questions. What does the practice really look like on a daily basis? What is the nature and severity of the harm caused by lobbying? Conversely, to what extent does lobbying activity produce societal gains? It concludes that lobbying is, by large, an activity which is beneficial for society. However, isolated incidents of lobbying occur which may have a disproportionately large, negative impact on government integrity and public confidence in governmental decision-makers. It follows that a regulatory system for lobbyists may be advisable if it is capable of minimising harmful lobbying without detriment to everyday lobbying activity.

\section{A Benefits of lobbying}

There can be little doubt that lobbying forms an integral part of the democratic process. It can be roughly characterised as contributory toward society in three ways.

Most broadly, lobbying can be rightly seen as a useful tool for political participation. ${ }^{50}$ An early iteration of this viewpoint was convincingly espoused by Arthur Bentley in his seminal text The Process of Government in 1908. He argued that interest groups were an essential component of democratic representation because they helped to balance interests across the political spectrum. ${ }^{51}$ Political engagement with interest groups, organisations, businesses and individuals from relevant democraticallyrepresented constituencies is clearly a desirable facet of democratic governance. The

\footnotetext{
${ }^{47}$ Lobbying Disclosure Bill 2012 (15-1) (select committee report) at 2.

${ }^{48}$ Isaac Davidson "MPs decide to restrict lobbyists unnecessary in 'village' NZ" The New Zealand Herald (online ed, Auckland, 24 August 2013).

${ }^{49}$ Lobbying Disclosure Act 19952 USC $§ 1601$, Findings; (Au) Code of Conduct, cl 1.1.

${ }^{50}$ Richard E Matland “Enhancing Women's Political Participation: Legislative Recruitment and Electoral Systems" in Julie Ballington and Azza Karam (eds) Women in Parliament: Beyond Numbers (International Idea, Stokholm, 2005) at 106.

${ }^{51}$ Arthur Fisher Bentley The Process of Government (Harvard University Press, 1967) 266.
} 
flow of information between the governed and those who govern ensures that the latter can respond to the wishes of the former, as befits proper representative democratic practice. The ability for constituents to contribute to political discourse is "precisely what distinguishes 'citizens' within a democracy from 'subjects' of an authoritarian regime." ${ }^{, 52}$ In other words, lobbying is part of a broader process which guarantees the legitimacy of democratic government.

Secondly, lobbying can also contribute to society by making insightful contributions to policy-making processes. It has been usefully described as a "legislative subsidy", 53 in the sense that lobbyists can offer valuable expertise to government representatives. Legislators are often "generalists", 54 meaning that they have a broad understanding of policy areas and methods for implementation. While this is obviously an essential characteristic of a skilled policymaker, it does not lend to detailed understandings of specific topics. This is where lobbyists step in, performing a crucial educational role. ${ }^{55}$ For example, the Mental Health Foundation of New Zealand is an organisation of professional mental health workers which develops policy advice on policies, systems or laws which affect people with experiences of mental illness. It provides evidencebased advice to government agencies such as Child, Youth and Family, the Ministry of Health and the Ministry of Social Development on these areas, helping to inform the policy process. ${ }^{56}$ The way in which lobbyists can inform policy agendas in New Zealand was exemplified by the expert, influential advice provided by technocrats during the deregulation of financial markets, which occurred between 1984 and $1995 .^{57}$ These lobbyists included the Employers' Federation, Federated Farmers and the Chambers of Commerce, who met regularly and resolved to dissect and promote the benefits of market liberalism to the governments at the time.

Finally, lobbyists can provide a counterbalance to the generally overpowered government of the day. ${ }^{58}$ For those public officials who do not have absolute access to the civil service and the advice it provides (such as backbench and opposition MPs), lobbyists can provide an informed perspective on issues, which can contribute to a more balanced political dialogue between representatives.

That lobbying is irreplaceably valuable is a fact beyond question. Without it, policy decisions would be based on an unbalanced representation of perspectives, and in isolation from the constituents for whom the policies are intended to apply. Lobbying is a legitimate practice, and attempts made to legislate must reinforce that fact. However, it is also apparent that lobbying can - from time to time - be rightly viewed as harmful.

\footnotetext{
${ }^{52}$ Will Kymlicka Contemporary Political Philosophy (2nd ed, Oxford University Press, 2002) at 289.

${ }^{53}$ Richard L Hall and Alan V Deardorff "Lobbying as Legislative Subsidy" (2006) 100 APSR 69 at 70

${ }^{54}$ Dorie Apollonio, Bruce E Cain, Lee Drutman "Access and Lobbying: Looking Beyond the Corruption Paradigm" (2008) 36 Hastings Const LQ 13 at 29.

${ }^{55}$ Dorie Apollonio, Bruce E Cain, Lee Drutman “Access and Lobbying: Looking Beyond the Corruption Paradigm" (2008) 36 Hastings Const LQ 13 at 29.

56 "Submissions and Policy Positions" (January 2013) New Zealand Mental Health Organisation <http://www.mentalhealth.org.nz/page/1297-submissions-policy-positions>.

${ }^{57}$ Richard Mulgan and Peter Aimer Politics in New Zealand (Auckland University Press, Auckland, 2004) at 222.

${ }^{58}$ Lionel Zetter Lobbying: The Art of Political Persuasion (Harriman House, Hampshire, 2008) at 1.3.
} 
As mentioned earlier, allegations of harm levelled against lobbying activity tend to fall into two categories. The first is that unregulated lobbying can detrimentally affect governmental integrity, by encouraging the misuse of public powers for the advancement of private interests. ${ }^{59}$ The second is a corollary of the first; namely, that unregulated lobbying activity can undermine public confidence in government representatives and decision-making processes. ${ }^{60}$

\section{$1 \quad$ Governmental integrity}

In one sense, "lobbying is just a special form of corruption focussed on legislative bodies or some other rule-making agency." ${ }^{61}$ This may be particularly true in cases where there is a quid quo pro assumption between the lobbyist and the government representative concerned (where there is an expectation held by the lobbyist that his or her view on certain issues will be given significant weight). This situation might arise where a lobbyist considers making a contribution to election campaign expenses, or offers gifts of a pecuniary or otherwise valuable nature. ${ }^{62}$ Harmful lobbying of this calibre - which clearly has negative implications for governmental integrity - is rare, compared to its everyday counterparts. However, this chapter demonstrates that this type of lobbying can cause more harm than the infrequency of its occurrence might suggest.

Some preliminary discussion is necessary before the interplay between lobbying activity and governmental integrity can be drawn out. Most essentially, it is necessary to consider what is meant by the vague word "integrity" with reference to governmental institutions and decision-making processes. In addition to this, the value of integrity must be appraised in order to determine the extent to which it merits protection.

\section{(a) Integrity and good governance}

Integrity is not an easily identifiable characteristic of governance. This is in large part due to the fact that it is highly subjective, and thus susceptible to various moral judgements. ${ }^{63}$ The term is tied up in the value-laden language of ethics and tends to vary between societies. One way to identify the degree to which government decisionmaking bodies act with integrity is to rate their performance against a number of indicators. The OECD Report on lobbying appears to use 'governmental integrity' almost synonymously with the principles of good governance. ${ }^{64} \mathrm{~A}$ similar approach

\footnotetext{
${ }^{59}$ OECD Lobbyists, Governments and Public Trust, Volume 1: Increasing Transparency through Legislation (OECD Publishing, 2009) at 19. Lobbying Disclosure Bill 2012 (15-1) (Explanatory note).

${ }^{60}$ OECD Lobbyists, Governments and Public Trust, Volume 1: Increasing Transparency through Legislation (OECD Publishing, 2009) at 19. Lobbying Disclosure Bill 2012 (15-1) (Explanatory note).

${ }^{61}$ Nauro F Campos and Francesco Giovannoni "Lobbying, Corruption and Political Influence (September 2006) Econstor <www.econstor.eu> at 1.

${ }^{62}$ The perennial example of the latter type of compensation seems to be corporate box tickets to sporting events. Tracey Watkins "The Rise and Rise of Lobbyists" (June 2011) Stuff - Politics <http://www.stuff.co.nz/national/politics/5099703/The-rise-and-rise-of-lobbyists>.

${ }^{63}$ G. Calvin Mackenzie and Michael Hafken Scandal Proof: Do Ethics Laws Make Government Ethical? (Brookings Institution Press, Washington DC, 2002) at 88.

${ }^{64}$ OECD Lobbyists, Governments and Public Trust, Volume 1: Increasing Transparency through Legislation (OECD Publishing, 2009) at 19.
} 
has been adopted in other scholarly works. ${ }^{65}$ Brought to prominence by the World Bank in the $1990 \mathrm{~s},{ }^{66}$ these "elastic" ${ }^{67}$ principles usually include "transparency, accountability, inclusiveness, effectiveness and impartiality." 68 These principles provide a useful starting-point for the evaluation of governmental integrity.

(i) Inclusiveness

Inclusiveness - or participation - refers to "the right to participate in public affairs directly or through chosen representatives." 69 This principle has become enshrined as one of the most essential for the creation of a legitimate state; many commentators believe it is an essential human right, and that "[i]n its absence... all others fall to a perilous existence." 70 It does not merely refer to election mechanisms, instead pertaining to the concept that a participatory approach to governance "mediates differing interests to reach a broad consensus on what is in the best interests of the group and, where possible, on policies and procedures." ${ }^{71}$ It requires that policymakers "follow an inclusive approach throughout the policy chain (from conception to implementation) to create more confidence in the result."72

Hypothetically, unethical lobbying could result in unbalanced consultation processes. This could occur where lobbyists are granted audiences with decision-makers, without corresponding input from other members of the electorate. This becomes unbalanced when audiences are granted on the basis of financial or political clout, instead of the merits of the argument offered or the degree to which the lobbying party represents public constituents. Where the former occurs, lobbying harms government integrity. The latter demonstrates how lobbying can achieve the opposite.

\section{(ii) Transparency and accountability}

Transparency and accountability are regularly discussed in tandem, given their relative proximity as principles of good governance. The exercise of public powers cannot be held accountable if the process by which they are determined is not made transparent. ${ }^{73}$ Governmental practice which adheres to the principles of accountability ensures that representatives are "held responsible for carrying out a defined set of

\footnotetext{
${ }^{65}$ Mark Evans “Beyond the Integrity Paradox: towards 'good enough' governance?” (2012) 33 Policy Stud J 97; Sam Agere Promoting Good Governance: Principles, Practices and Perspectives (Commonwealth Secretariat, 2000) at 4.

${ }^{66}$ Ved P Nanda "The 'Good Governance' Concept Revisited" (2006) 603 Ann Am Acad Polit Soc Sci 269 at 271.

${ }^{67}$ Martin Doornbos “'Good Governance': The Rise and Decline of a Policy Metaphor?” (2001) 37 J Dev Stud 93 at 95.

${ }^{68}$ Bertrand Badie, Dirk Berg-Shlosser and Leonardo Morlino International Encyclopaedia of Political Science (Sage Publications, 2011) "Governance, Good". For the sake of balance, it should be noted that these characteristics form only the "liberal half" of good governance. Its counterpart - the "statist half" - includes authority, order, capability and autonomy. Christophe Béné and A Neiland From Participation to Governance (WorldFish, Malaysia, 2006) at 8.

${ }^{69}$ International Covenant on Civil and Political Rights (adopted 16 December 1966, entered into force 23 March 1976), art 25.

${ }^{70}$ Henry J Steiner "Political Participation as a Human Right" (1988) 1 Harv Hum Rts YB 77 at 78.

${ }^{71}$ John Graham, Bruce Amos \& Tim Plumptre Policy Brief No 15: Principles for Good Governance in the $21^{\text {st }}$ Century (Institute on Governance, 2003) at 3.

${ }^{72}$ Veerle Van Deoveren "Rethinking Good Governance" (2011) 13 Pub Integ 301 at 309.

${ }^{73}$ Frank Bannister \& Regina Connolly "The Trouble with Transparency: A Critical Review of Openness in e-Government” (2011) 3 Policy Internet 121 at 124.
} 
duties or tasks, and for conforming with rules of standards applicable to their posts." Transparency is often used interchangeably with "openness" ${ }^{75}$ The OECD defines it as referring to: ${ }^{76}$

...an environment in which the objectives of policy, its legal, institutional and economic framework, policy decisions and their rationale, data and information related to monetary and financial policies, and the terms of agencies' accountability, are provided to the public in a comprehensible, accessible and timely manner.

In the absence of transparency in lobbying, the activity becomes "obscured and an environment is created where coercion and corruption can occur." "Without this transparency, those government representatives who allow for the influence of harmful lobbying activity cannot be held to account.

(iii) Impartiality

Impartiality requires decision-makers to act with regard only to those facts which suitable for consideration in policy or law. ${ }^{78}$ It means that government representatives and institutions must be "unmoved by certain sorts of considerations - such as special relationships and personal preferences." 79 The implications of this principle for unregulated lobbying is clear; those lobbyists who have developed relationships with decision-makers may secure favourable outcomes for reasons other than those which are strictly egalitarian in nature.

\section{(b) Identifying harm to governmental integrity}

It is no simple matter to ascertain the degree to which lobbying activities detrimentally affect governmental integrity. Much of it takes place behind closed doors. It is reasonable to assume that most instances of lobbying which fall on the less ethical end of the spectrum are less likely to see the light of day (particularly in those jurisdictions without relevant transparency legislation), which compounds the issue. Lobbyists have specialist knowledge about the workings of outwardly complicated decision making processes, which suggests that they might have the ability to manipulate democratic procedures for self-interested purposes. This can be concerning where the impact of lobbying activity alters the outcome of a process which diverts funding or attention from other, potentially more meritorious, causes. The difficulty lies in determining whether the lobbying activity had a material impact on the result.

The OECD points to the amount of lobbying which took place around the United States Troubled Asset Relief Program (TARP) - and the way in which funds were subsequently distributed - as an accurate reflection of the dangerous power of lobbyists. The report refers to this as an example of how lobbyists can impact the outcome of decisions, even where these decisions are of a great deal of consequence.

\footnotetext{
${ }^{74}$ OECD “Accountability” (April, 2013) Glossary of Statistical Terms

<http://stats.oecd.org/glossary/detail.asp?ID=4757>.

${ }^{75}$ Veerle Van Deoveren "Rethinking Good Governance" (2011) 13 Pub Integ 301 at 309.

${ }^{76}$ OECD "Transparency" (July, 2002) Glossary of Statistical Terms

$<$ http://stats.oecd.org/glossary/detail.asp?ID=4474>.

${ }^{77}$ OECD Lobbyists, Governments and Public Trust, Volume 1: Increasing Transparency through Legislation (OECD Publishing, 2009) at 40.

${ }^{78}$ Bo Rothstein and Jan Teorell "What is Quality of Government? A Theory of Impartial Government Institutions" (2008) 21 Governance 165 at 170.

${ }^{79}$ Geoffrey Cupit “When Does Justice Require Impartiality?” (paper presented to Political Studies Association Annual Conference, London, 10 April 2000).
} 
TARP was originally intended to allocate an enormous $\$ 700$ billion in expenditures to bailout the automotive and financial services sectors. ${ }^{80}$ These sectors spent $\$ 77$ million in lobbying during the bailout program, and $\$ 37$ million on campaign contributions during the 2008 Presidential Elections. ${ }^{81}$ In return, they received $\$ 295.2$ billion in assistance, which is an investment return of $258,499 \%$, if it is assumed that lobbying had a central role in this allocation. There is some data to suggest that this assumption is correct. Those companies which contributed most generously to lobbying and election campaigns were also those which received the highest amount of TARP investment. ${ }^{82}$ This correlation seems to indicate the prevalence of a "squeaky wheel gets the oil" approach to the distribution of asset relief, which has clear and dire implications for the notions of impartiality and inclusiveness.

While this example bolstered the case for reform espoused by the OECD in its Lobbyists, Governments and Public Trust, Volumes 1 \& 2, it does not make one specifically for the implementation of such regulations in New Zealand. Despite this, the information available on a number of high-profile instances of lobbying in New Zealand seem to paint a similar picture - if in a somewhat smaller magnitude - to that created by TARP fund distribution.

$$
\text { "SkyCity deal" }
$$

In recent years, the so-called "SkyCity Deal" ${ }^{83}$ has thrust lobbying firmly into the public spotlight. The Gambling Act 2003 imposes a range of restrictions over the gambling industry, including the prohibition of any increase in opportunities for casino gambling. ${ }^{84}$ This imposed a restriction on the potential revenue earnings from SkyCity Entertainment Group's gambling interests. SkyCity brought a series of unsuccessful cases before the courts to have these provisions interpreted favourably, either by reading exclusions into the Act or on the basis of ejusdem generis arguments. ${ }^{85}$ Having exhausted this avenue, the company began to lobby the National Party minority government following its success in the 2008 General Elections.

The Crown eventually agreed to grant several concessions to gambling restrictions to SkyCity Entertainment Group in exchange for the construction and operation of the New Zealand International Convention Centre. ${ }^{86}$ The process by which this agreement

\footnotetext{
${ }^{80}$ OECD Lobbyists, Governments and Public Trust, Volume 2: Promoting Integrity through SelfRegulation (OECD Publishing, 2009) at 31.

${ }^{81}$ OECD Lobbyists, Governments and Public Trust, Volume 2: Promoting Integrity through SelfRegulation (OECD Publishing, 2009) at 29.

82 “TARP Recipients Paid Out \$114 Million for Politicking Last Year" (4 February 2009) OpenSecrets: Centre for Responsive Politics <www.opensecrets.org/news/2009/02/tarp-recipients-paid-out-114m.html>.

83 "SkyCity deal unveiled: \$402m centre, 230 more pokies" The New Zealand Herald (online ed, Auckland, 13 May 2013).

${ }^{84}$ Gambling Act 2003, s 11.

${ }^{85}$ For example, it argued that s 4 of the Gambling Act 2003 should not include electronic roulette as a form of "gaming machine". SkyCity Auckland Ltd v Gaming Commission \& Department of Internal Affairs HC Auckland CIV 2005-404-000958 22 November 2005; SkyCity Auckland Ltd \& Anor v Gambling Commission HC Auckland CIV-2005-404-001369, 24 August 2006; SkyCity Auckland Ltd \& Anor v Gambling Commission [2008] 2 NZLR 182.

${ }^{86}$ The agreement between the New Zealand International Convention Centre and the Crown is available on <http://www.med.govt.nz/sectors-industries/regions-cities/pdf-docs-library/nzinternational-convention-centre/heads-of-agreement-12-May-2013.pdf> (last accessed 24 January 2014).
} 
was reached was the subject of an inquiry by the Controller and Auditor-General, which was published in February 2013. ${ }^{87}$ The report gave the public a rare glimpse into the process by which lobbying can occur in New Zealand. It found that there was a "range of deficiencies in the advice that the Ministry provided and the steps that the officials and Ministers took leading up to that decision [to negotiate with SkyCity]." 88 The report concluded that there was "no evidence to suggest that the final decision to negotiate with SkyCity was influenced by any inappropriate considerations", ${ }^{89}$ but the various concerns raised by the Auditor-General indicate that it is doubtful that the Government acted with integrity throughout the process.

Crucially, the Report questioned the overall robustness of the negotiation process: ${ }^{90}$

By the time it was expected that SkyCity would put a firm proposal to the Government for support, officials should have been working to understand and advise on the procedural obligations and principles that would need to govern the next steps. We found no evidence that officials were doing so at this stage.

It is probable that SkyCity's lobbying activity undermined the even-handedness of the expression of interest (EOI) process initiated by the Ministry of Economic Development in 2010. The EOI called for proposals to construct an international convention centre. The Auditor-General's report found that SkyCity was "treated differently from the others during the evaluation". ${ }^{91}$ Suspicions of a strong risk of bias going into the EOI process were confirmed when the Auditor-General's office described the prior relationship that existed between SkyCity and the Prime Minister. It noted that no considerations were made to ensure the integrity of the tender process to offset the risks posed by the pre-existing relationship between the Government and SkyCity. One Treasury official remarked that to ensure the application of due process and probity, it "would require, at a minimum, an open and transparent assessment of other options", ${ }^{92}$ but this recommendation was largely ignored.

The language used by the Auditor-General is unambiguous. The impartiality of the process was undermined by the failure to manage the risks posed by SkyCity's prior lobbying efforts. This criticism was magnified by the release of Treasury documents in August 2013, which showed that the Treasury doubted the economic benefits of the SkyCity tender outweighed the economic costs and social harm that were likely to

\footnotetext{
${ }^{87}$ Inquiry into the Government's decision to negotiate with SkyCity Entertainment Group Limited for an international convention centre (Office of the Controller and Auditor-General, Independent Assurance Report, February 2013).

${ }^{88}$ Inquiry into the Government's decision to negotiate with SkyCity Entertainment Group Limited for an international convention centre (Office of the Controller and Auditor-General, Independent Assurance Report, February 2013), 2.

${ }^{89}$ Inquiry into the Government's decision to negotiate with SkyCity Entertainment Group Limited for an international convention centre (Office of the Controller and Auditor-General, Independent Assurance Report, February 2013), 2.

${ }^{90}$ Inquiry into the Government's decision to negotiate with SkyCity Entertainment Group Limited for an international convention centre (Office of the Controller and Auditor-General, Independent Assurance Report, February 2013), 9.

${ }^{91}$ Inquiry into the Government's decision to negotiate with SkyCity Entertainment Group Limited for an international convention centre (Office of the Controller and Auditor-General, Independent Assurance Report, February 2013), 21.

${ }^{92}$ Inquiry into the Government's decision to negotiate with SkyCity Entertainment Group Limited for an international convention centre (Office of the Controller and Auditor-General, Independent Assurance Report, February 2013), 21.
} 
result. ${ }^{93}$ Further to the lack of impartiality cited in the report, the Office voiced concerns over the lack of transparency evident throughout interactions between the Government and SkyCity. ${ }^{94}$ By the measure of the principles impartiality and transparency, it is apparent that lobbying detrimentally affected the integrity of governmental decision-making processes in the determination of the New Zealand International Convention Centre agreement.

(ii) The "Hobbit Law"

In 2010, California-based film production studios Warner Brothers conducted a highly successful lobbying campaign, following conflict which arose between it and the New Zealand actors' guild, New Zealand Actors Equity.

Earlier that year, New Zealand Actors Equity had unsuccessfully tried to negotiate with production companies and directors to secure standard contracts for actors in local productions. ${ }^{95}$ New Zealand employment law makes a distinction between 'employees' and 'independent contractors'. The former receives a range of legislative benefits. Employees are protected from unfair dismissal, and are granted a range of entitlements, including sick leave, minimum wages and fair annual leave. ${ }^{96}$ Independent contractors do not receive these benefits. Hypothetically, independent contractors are instead granted the right to "be free to choose the nature of their employment agreement", ${ }^{97}$ and they receive a range of tax concessions and expenses rebates. ${ }^{98}$ Some argue that these benefits are negligible, which creates a contractual inequality. ${ }^{99}$ This problem is exacerbated by practices followed by the New Zealand acting industry, which is almost exclusively operated on an independent contractor basis. 100

Most crucially, independent contractors are prohibited from almost all forms of collective bargaining. ${ }^{101}$ Taking issue with this, and having failed to convince Warner Brothers to enter into negotiations, the International Federation of Actors issued an industry-wide notice, instructing its members "not to agree to act in the films until the company enters into a collective bargaining agreement." ${ }^{102}$ This move stifled the casting process for The Hobbit, delaying production work and hurting profits. The Hobbit director Sir Peter Jackson issued a press release in September. It mentioned that - if made necessary by the ongoing actors' strike - the filming could be carried

\footnotetext{
${ }^{93}$ Cabinet Briefing Paper "New Zealand International Convention Centre" (16 December 2011) $\mathrm{P} / 043 / \mathrm{PR} 011$ at [13].

${ }^{94}$ Inquiry into the Government's decision to negotiate with SkyCity Entertainment Group Limited for an international convention centre (Office of the Controller and Auditor-General, Independent Assurance Report, February 2013), 5, 21.

${ }^{95}$ A F Tyson "A Synopsis of the "Hobbit Dispute" (2011) 36 NZJER 6.

${ }^{96}$ Holidays Act 2003, ss 16, 65: Bernard Walker "How does non-standard employment affect workers? A consideration of the evidence" NZJER 14 at 18.

${ }^{97}$ Margaret Wilson "Constitutional Implications of 'The Hobbit' Legislation" (2011) 36 NZJER 90 at 93.

${ }^{98}$ Barbara Burton "Non-standard Work: an Employer Perspective" 42 (2011) 36 NZJER 37 at 42.

${ }^{99}$ Margaret Wilson "Constitutional Implications of 'The Hobbit' Legislation”" (2011) 36 NZJER 90 at 94.

${ }^{100}$ Kate Wilkinson “One Law to Rule Them All” (2011) 36 NZJER 34 at 35.

${ }^{101}$ Helen Kelly "The Hobbit Dispute" (2011) 36 NZJER 30 at 32.

${ }^{102}$ A F Tyson "A Synopsis of the "Hobbit Dispute" (2011) 36 NZJER 6.
} 
out in another country. If this was to happen, Mr Jackson predicted a "long dry big budget movie drought in this country." 103

Soon after this, Warner Brothers and Sir Peter Jackson lobbied Ministers Gerry Brownlee and Chris Finlayson directly. The meeting occurred in October 2010, and was presumably about seeking a solution to these issues. Soon after this, prominent Government MPs began to echo the concerns raised in Sir Jackson's press release, citing the economic advantages that the production could bring to New Zealand. ${ }^{104}$ The accepted line across Government members was that in the absence of an amendment, The Hobbit would go offshore. ${ }^{105}$ That this potential scenario was explicitly denied by Sir Peter Jackson weeks before its assent did not stop the Government from passing an amendment largely on that impetus. ${ }^{106}$ The Employment Relations (Film Production Work) Amendment Bill (299-1) was passed into law on 29 October 2010, flying through Parliament in two days under urgency powers. The Amendment declared that all persons engaged in film production work in any capacity are independent contractors for the purposes of the Employment Relations Act $2000 .^{107}$

One of the key issues presented by the Hobbit Law process was a lack of inclusiveness. The Actors' union, New Zealand Actors Equity and the International Federation of Actors aimed to secure access for actors to collective bargaining arrangements. ${ }^{108}$ An inclusive process would have involved consultation with these groups, the acting industry and the wider public. Instead, the Amendment was passed under urgency, which allows Parliament to pass legislation without the usual process of consultation and submissions. ${ }^{109}$

There was a shroud of secrecy over much of the activities which surrounded the passage of the Amendment Bill. Media organisations and the Council of Trade Unions requested copies of all documents pertaining to deals made between the Government and Warner Brothers under the Official Information Act 1982. ${ }^{110}$ Limited disclosure resulted, which culminated in an investigation by the Ombudsmen. ${ }^{111}$ It found that ministers had failed to adhere to the provisions of the Act by deleting or failing to disclose information which was rightfully obtainable. ${ }^{112}$ The information request process, which took almost two years, involved two occasions where ministers cancelled meetings with the Ombudsman at the last moment. Repeated requests for information were denied on the basis that the investigation could "impede [the

\footnotetext{
${ }^{103}$ Peter Jackson "Statement regarding The Hobbit and claims by MEAA" (press release, 27 September 2010).

${ }^{104}$ (28 October 2010) 668 NZPD 14957.

105 (28 October 2010) 668 NZPD 15041.

${ }^{106}$ New Zealand Actors Equity "NZ Actors Equity responds to new Hobbit information" (press release, 27 April 2012).

${ }^{107}$ Employment Relations (Film Production Work) Amendment Bill (299-1), cl 4.

${ }^{108}$ A F Tyson "A Synopsis of the "Hobbit Dispute" (2011) 36 NZJER 6.

${ }^{109}$ Bernard Walker and Rupert Tipples "Voiceless Actors: The Hobbit Affair and the Future of Unions" (presented at Voices at Work Australasian Meeting, Melborne, 21 July 2012).

${ }^{110}$ Helen Kelly "The Hobbit Dispute" (12 April 2011) Scoop Independent News

<http://www.scoop.co.nz/stories/HL1104/S00081/helen-kelly-the-hobbit-dispute.htm\#ftn>.

${ }^{111}$ David McGee Requests for information regarding the production of The Hobbit and film production generally (Office of the Ombudsman, Ombudsman's opinion 302561 \& 302600, 31 January 2013).

${ }_{112}$ David McGee Requests for information regarding the production of The Hobbit and film production generally (Office of the Ombudsman, Ombudsman's opinion 302561 \& 302600, 31 January 2013) at 10.
} 
Government's] ability to conduct full free and frank negotiations in the future." ${ }^{\prime 13}$ This result is quite clearly at odds with the good governance principle of transparency.

In supporting the Employment Relations (Film Production Work) Amendment Bill, the Government freely admitted that it the main impetus for the change came from Warner Brothers. ${ }^{114}$ Despite this, it failed to adequately appreciate and compensate for the risks that this type of lobbying can have on the integrity of decision-making processes.

(c) Lobbying and harm to governmental integrity - concluding remarks

The SkyCity deal and the Hobbit Law do not reflect the mundane and largely beneficial daily interactions which take place between government representatives and third parties. That being said, these activities do establish that - at its worst - lobbying can detrimentally affect governmental integrity and thus has the potential to cause harm.

\section{$2 \quad$ Public confidence}

It is a much more difficult task to determine whether unregulated lobbying can detrimentally affect public confidence in government institutions and actors. In the absence of polling data or other direct samples of public perception, researchers are forced to turn to less certain indicators. Although they do not provide definitive evidence, this analysis considers three indicators of public sentiment in search for a more reliable foundation for the allegation that lobbying activity may decrease public confidence. The first indicator is the limited polling evidence available, most of which has been conducted with respect to public perception towards lobbying and the United States Congress, the Parliament of the United Kingdom and the European Commission. ${ }^{115}$ The second and third indicators consider expressions made by prominent news media outlets and public figures, where these expressions link failing democratic legitimacy and lobbying activity.

(a) Polling

Lobbying is common to all liberal democracies, many of which have witnessed strong public opposition to the practice. Although direct polling evidence in regards to lobbying and public confidence is not available in New Zealand, recent surveys have been conducted in other jurisdictions. Perhaps unsurprisingly, the outcomes of these polls have consistently reflected a dismal view of lobbying activity held by members of the public.

The most condemning result came from a Taylor Nelson Sofres opinion poll conducted in January 2013. ${ }^{116}$ Conducted at the behest of the European Union Citizens project, the poll found that over three-quarters of those surveyed thought lobbying can undermine public interest and that the practice should be regulated, and

\footnotetext{
${ }^{113}$ David McGee Requests for information regarding the production of The Hobbit and film production generally (Office of the Ombudsman, Ombudsman's opinion 302561 \& 302600, 31 January 2013) at 9. 114 (28 October 2010) 668 NZPD 15041.

${ }^{115}$ EU Citizens opinion poll on transparency, ethics and lobbying in the EU (briefing paper, EU Citizens, February 2013).

${ }^{116}$ EU Citizens opinion poll on transparency, ethics and lobbying in the EU (briefing paper, EU Citizens, February 2013).
} 
70 per cent agreed that "it is widely known that lobbyists have a strong influence on European Union policy-making." 117 This demonstrates a strong link between public confidence and lobbying in the European Union countries studied. It should be noted that some key differences between the European Union and New Zealand contexts limit the usefulness of this study. The European Union is frequently characterised as being in a state of democratic deficit. ${ }^{118}$ This crisis of legitimacy is compounded by the fact that lobbying is an institutionalised process in the European Union. This is largely due to two factors. The first is that sheer scale of the European Union requires interested parties to form larger groups in order to succeed in their goals. The second is because the European Union's growth of authority has necessitated the growth of lobbying activity to provide "information on complex regional economic issues"119 The particularly potent combination in the European Union - a severe democratic deficit and institutionalised lobbying practices - has given rise to a virulent form of anti-lobbying sentiment.

Similarly, a 2004 CBS News/New York Times poll found a majority of United States citizens believed that the government will do what is right only some of the time, and that "government is pretty much run by a few big interests looking out for themselves." ${ }^{120}$ Further to this, the annual Gallup Honesty/Ethics in Professions poll regularly features lobbyists amongst the least-trusted professions. In 2008, lobbyists rated as the single least trusted profession in the United States. ${ }^{121}$

From these polls it is fair to infer that some kinds of lobbying activity can be detrimental to public confidence in government institutes and decision making processes. However, it is not immediately apparent whether this anti-lobbying sentiment is found only where lobbying has regularly been the cause and subject of controversy, or whether this harm is omnipresent in democracies, including in states such as New Zealand.

(b) News media and public figures

The news media has a strong influence on public awareness, ${ }^{122}$ but this relationship flows both ways. The news media selectively produce news items based on the degree of public interest they are likely to generate. Often, as one study demonstrated, "the role of the news media [is] one of reinforcement rather than change." ${ }^{123}$ Regardless of which is true, it remains true that the perspectives given by news media generally run parallel to public opinion (or large demographics therein).

\footnotetext{
117 "European poll shows considerable concern about EU ethics, transparency and lobbying" (31 January 2013) EU Citizens: Citizens in the European Union <http://www.eucitizens.org/noticia10.php>.

${ }^{118}$ Such views are popular, but may be unfounded according to Andrew Moravcsik, "In Defence of the 'Democratic Deficit': Reassessing Legitimacy in the European Union" (2002) 40 JCMS 603 at 604.

${ }^{119}$ Justin Greenwood and Mark Aspinwall (eds) Collective Action in the European Union: Interests and the new politics of associability (Routlege, 1998) at 5.

${ }^{120}$ Revolving Door Working Group "A Matter of Trust: How the Revolving Door Undermines Public Confidence in Government" (October 2005) Revolving Door <www.revolvingdoor.info>.

${ }^{121}$ Jeffrey M Jones "Record 64\% Rate Honesty, Ethics of Members of Congress Low" (12 December 2011) Gallup Politics <http://www.gallup.com/poll/151460/record-rate-honesty-ethics-memberscongress-low.aspx $>$.

${ }^{122}$ Max McCombs, R Lance Holbert, Spiro Kiousis and Wayne Wanta The News and Public Opinion: Media Effects on Civic Life (Polity, Cambridge, 2011) at 164.

${ }^{123}$ Max McCombs, R Lance Holbert, Spiro Kiousis and Wayne Wanta The News and Public Opinion: Media Effects on Civic Life (Polity, Cambridge, 2011) at 99.
} 
Given this relationship, it is illuminating to view the way in which lobbying activities are handled in the news. The coverage received by scandals is particularly telling. The SkyCity debate garnered massive news media attention. It was (and still is) characterised by criticisms of the decision-making processes involved, which were allegedly compromised by SkyCity's lobbying activities. ${ }^{124}$ Similarly negative responses towards the connection between lobbying and poor decision-making practices were produced by news media outlets following the Hobbit Law scandal. ${ }^{125}$ Another example of this was the news media response to the WikiLeaks cables which showed that the United States Government lobbied New Zealand intensely on the widely criticised Copyright (Infringing File Sharing) Amendment Act 2005. ${ }^{126}$

Despite representing only a small sample size of society, statements made by public figures can give some insight into public mood. Greenpeace made a public statement about allegations surrounding unethical lobbying practices of Energy Minister Simon Bridges in July 2013. It erected a 300 square-metre sign in central Wellington, which featured a poster of the Minister and the words "Simon Bridges Pants on Fire". ${ }^{127}$ On April 9 the Minister introduced Supplementary Order Paper 205 to the Crown Minerals (Permitting and Crown Land) Bill (70-2). It introduced an "Anadarko amendment" 128 which limited the right to protest in New Zealand's Exclusive Economic Zone. By using an SOP to amend the Bill, the Minister avoided making the matter subject to public debate and scrutiny. As two commentators noted, "the introduction of significant law changes by way of SOP bypasses the normal vetting processes and increases the risk of sloppy law-making." ${ }^{29}$ Greenpeace believe that, contrary to statements made by the Minister before the House, Simon Bridges and Steven Joyce met with oil companies from 4 September 2012. It is alleged that on these occasions, the companies expressed "concern about protests at sea and what they call the Government's 'insufficient legal authority"". ${ }^{130}$ If true, then it is possible that oil companies have contributed towards the development of policy which was passed without due process. This policy prescribes an explicit limitation on a number

\footnotetext{
${ }^{124}$ David Fisher "SkyCity Wooed Govt after Court Failures" The New Zealand Herald (online ed, Auckland, 18 April 2012); Kate Chapman "Deal would be Transparent under Register" The Dominion Post (online ed, Wellington, 25 April 2012); John Carran "SkyCity Deal sends Wrong Message" The New Zealand Herald (online ed, Auckland, 08 May 2012); Adam Bennett, David Fisher "Select Treatment for SkyCity won't stop deal" The New Zealand Herald (online ed, Auckland, 20 February 2013); Matt Nippert “A license to print money?” The Dominion Post (online ed, Wellington, 27 July 2013); Bernard Orsman "Super City Elections 2013: Mayor accused of pokies u-turn" The New Zealand Herald (online ed, Auckland, 2 October 2013).

125 "Academic slams 'Hobbit Law' bid" The New Zealand Herald (A5, Auckland, 25 October 2010); "Hobbit law passes, but not everybody on board" National Business Review (online ed, Auckland, 29 October 2010); Claire Trevett "Sparks fly in 'Hobbit Law' debate" The New Zealand Herald (online ed, Auckland, 29 October 2010); “Govt 'comfortable' with handling of Hobbit dispute" (26 February 2013) ONE News <http://tvnz.co.nz/national-news/govt-comfortable-handling-hobbit-dispute5354100>; "Govt lied about Hobbit dispute timeline - union" (27 February 2013) ONE News <http://tvnz.co.nz/national-news/govt-lied-hobbit-dispute-timeline-union-5354648>.

${ }^{126}$ Chris Keall "WikiLeaks cables: US govt pressured NZ over internet file sharing law" National Business Review (online ed, Auckland, 2 May 2011).

${ }^{127}$ Greenpeace "Pants on fire - billboard questions Minister's contacts with oil company" (press release, 16 July 2013)

${ }^{128}$ Green Party "Govt abuses urgency to extend Anadarko Amendment” (press release, 17 May 2013).

${ }^{129}$ Nikki Pender and Pam McMillan "SOP sinks mining protestors" Lawtalk (online ed, Wellington, 26 April 2013).

${ }^{130}$ Greenpeace "Pants on fire - billboard questions Minister's contacts with oil company" (press release, 16 July 2013).
} 
of human rights, most notably for the right to freedom of peaceful assembly. ${ }^{131}$ Greenpeace erected the billboard with the view that this potentially harmful lobbying activity would cause for concern the New Zealand public. If this anticipated audience exists, it is likely that a large number of New Zealanders share the view that lobbying can undermine trust in government decision-making processes.

A notable authority of lobbying has also given a hesitant endorsement for the introduction of lobbyist regulations. Prominent public law expert Mai Chen believed that the SkyCity scandal demonstrated a need to increase transparency around lobbying activity, in order to cater for the "public's expectation of transparency [which is] growing, for both government and business, especially in light of the Global Financial Crisis and the various high-profile misdemeanours of professionals and advisors." ${ }^{132}$ In addition to this, a number of the submissions made on the Lobbying Disclosure Bill expressed a general concern about lobbying practices in New Zealand. ${ }^{133}$

(c) Lobbying and harm to public confidence - concluding remarks

These sources and indicators of public opinion provide some evidence to suggest that lobbying is held in low regard by many New Zealand. Opposition is at its most vehement when it appears that governmental representatives have allowed the practice to strongly influence decision-making processes. This lends weight the OECD suggestion that lobbying can harm public confidence in governmental integrity.

The significance of trust in government was compellingly espoused by John Locke his Second Treatise of Government, in which he stated "by breach of this trust [governments] forfeit the power the people had put into their hands... and it devolves to the people, who have a right to resume their original liberty, and, by the establishment of a new legislative." "134 There is a broad consensus in modern literature that "citizens must trust government if government is to work well and that a reputed decline in citizen trust of government bodes ill for many contemporary democratic society."

If high-profile lobbying events are indeed detrimental to public confidence, then recent scandals have come at a particularly bad time. There are links between public trust and civic participation; a decline in the former is often reflected as a fall in the latter. ${ }^{136}$ In New Zealand, both local and general elections have seen voter turnouts drop to record-breaking lows in recent years. ${ }^{137}$ The 2011 General Elections saw

\footnotetext{
${ }^{131}$ New Zealand Bill of Rights Act 1990, s 16: Nikki Pender and Pam McMillan "SOP sinks mining protestors" Lawtalk (online ed, Wellington, 26 April 2013).

${ }^{132}$ Mai Chen "SkyCity ruckus shows why lobbying bill needed" The New Zealand Herald (online ed, Auckland, 26 April 2012).

${ }^{133}$ Amnesty International Aotearoa New Zealand "Submission to the Government Administration Select Committee on the Lobbying Disclosure Bill"; The Salvation Army "Lobbying Disclosure Bill: Government Administration Committee" at [3.6]; Volunteering New Zealand "Submission to the Government Administration Committee regarding Lobbying Disclosure Bill”.

${ }^{134}$ John Locke Second Treatise of Government (Hayes Barton Press, 1952) at 133.

${ }^{135}$ Russell Hardin "Do we want trust in government?" in Mark E Warren (ed) Democracy and Trust (Cambridge University Press, 1999) at 22.

${ }^{136}$ Eric M Ulsaner "Democracy and social capital” in Mark E Warren (ed) Democracy and Trust (Cambridge University Press, 1999) at 135

137 "Party votes and turnout by Electorate" (November 2011) Electoral Commission - Statistics <http://www.electionresults.govt.nz/electionresults_2011/e9/html/statistics.html>.
} 
under three-quarters of eligible voters cast a ballot, which is the lowest turnout since $1887 .{ }^{138}$ This number was around a mere $40 \%$ for local body elections which took place in 2013. ${ }^{139}$ If these trends are even slightly causally related to trust in governmental integrity, then it is possible that lobbying is compounding the problems caused by already low levels of public confidence.

\section{Conclusions}

It is plain that lobbying activity is a desirable and contributory aspect of a functional democracy. It can bring legitimacy to decision-making process through the facilitation of participation, and helps to inform government representatives on areas of interest. However, it is also apparent that the OECD was correct in identifying a number of harms which lobbying can cause. In New Zealand, unregulated lobbying practices have come at a cost to government integrity and public trust in the integrity of decision-making processes. What remains is a need for regulations which discourage harmful instances of lobbying without otherwise impeding the wider practice.

\footnotetext{
138 “General Elections 1853-2011 - Dates and Turnout” (9 September 2013) Electoral Commission <http://www.elections.org.nz/events/past-events/general-elections-1853-2011-dates-and-turnout>. ${ }^{139}$ Claire Trevett "Local elections 2013: Low turnout spurs look at vote system" The New Zealand Herald (online ed, Auckland, 14 October 2013).
} 


\section{Lobbying and Extant Public Law Tools}

The Lobbying Disclosure Bill was rejected by the select committee primarily due to a variety of perceived drafting deficiencies. ${ }^{140}$ However, the Chair of the Government and Administration Committee later explained that it was also because it was thought that existing measures were sufficient to regulate New Zealand's "village" lobbying environment. ${ }^{141}$ It is beyond question that tools should only be added to the public law arsenal after careful consideration. It follows that new public law tools should be tailored to remedy a specific problem or area which is not already covered by available tools. If public law mechanisms exist which have some relevance to the issue at hand, an additional measure could become counterproductive by "blurring"142 responsibilities (due to a lack of clarity between instruments) and by causing overlapping jurisdictional issues. Those laws that establish a monitoring or enforcement agency might also find that it is under-resourced, or that its allocation of funding comes at the consequence to the funding of neighbouring agencies. ${ }^{143}$

On the other hand, the benefits of increased transparency and accountability through the proliferation of public law tools are not insignificant. Without freedom of information, citizens cannot hope to understand - let alone react to - government decision-making processes. ${ }^{144}$ Voters cannot "check or encourage what they were not permitted to see". ${ }^{145}$ Sufficiently armed with knowledge, however, citizens are enabled to meaningfully contribute to political dialogue. Transparency also discourages unethical or corrupt behaviour by ensuring that those who have committed transgressions are made publically accountable. ${ }^{146}$

This chapter canvasses the current relevant laws and rules surrounding the lobbying activity in New Zealand in order to highlight areas where this may be lacking. To identify these gaps, it is first necessary to determine which concepts are addressed in lobbying legislation in other jurisdictions. In its first volume on Lobbyists, Government and Public Trust, the Organisation for Economic Co-operation and Development outlined five requirements for a sound lobbying framework: ${ }^{147}$

- Standards and rules that adequately address public concerns and conform to the sociopolitical and legal context.

- A legislation or regulation that suitably defines the actors and activities covered.

- Standards and procedures for disclosing information that cover key aspects of lobbying such as its intent, beneficiaries and targets.

- Enforceable standards of conduct for fostering a culture of integrity by, for instance, avoiding conflict of interest and providing accurate information.

\footnotetext{
${ }^{140}$ Lobbying Disclosure Bill 2012 (15-1) (select committee report) 3.

${ }^{141}$ Issac Davison "MPs decide law to restrict lobbyists unnecessary in "village' NZ" The New Zealand Herald (online ed, Auckland, 24 August 2013) as per MP Ruth Dyson (Government Administration Committee Chair).

${ }^{142}$ Mai Chen Public Law Toolbox (1st Edition, Lexisnexis, Wellington, 2012) at 42.

${ }^{143}$ Mai Chen Public Law Toolbox (1st Edition, Lexisnexis, Wellington, 2012) at 42.

${ }^{144}$ Sadhir Kumar "Study of Freedom of Information Act, US and Right to Information Act, India" (paper presented to $40^{\text {th }}$ Annual Indian Association for American Studies, Coimbatore, 11 August 2010) at 4.

${ }^{145}$ John Stuart Mill Considerations on Representative Government (Prometheus Publishers, New York, 1991), 42.

${ }^{146}$ G Calvin Mackenzie and Michael Hafken Scandal Proof: Do Ethics Laws Make Government Ethical? (Brookings Institution Press, Washington DC, 2002) at 20.

${ }^{147}$ OECD Lobbyists, Governments and Public Trust, Volume 1: Increasing Transparency Through Legislation (OECD Publishing, 2009) at 11.
} 
- A coherent spectrum of strategies and practices that secure compliance with standards and rules.

These requirements are not exhaustive, but they do provide a useful index for the purposes of this chapter. By referring to general objectives instead of prescribing model legislation, the OECD requirements for a sound lobbying framework can be incorporated into jurisdictions as respective governments see fit. This chapter uses these requirements as generalised descriptors of comprehensive approaches to lobbying regulation in order to determine whether any of these functions are already performed by existing laws and rules.

If these requirements are already met by existing measures in New Zealand, further regulation may be unnecessary. If they are only partially met, proposed regulation must meet the unfilled requirements without interfering with the functions of existing measures. There are several measures - legislative and otherwise - which already apply to the conduct of lobbyists in New Zealand. When evaluated against the OECD requirements, the gaps in the current arrangement become evident.

\section{A Existing measures}

\section{$1 \quad$ Crimes Act 1961 and corruption and bribery offences}

If we accept that lobbying is the act of "seeking to influence members of [the] legislature", ${ }^{148}$ then the most explicitly unethical form of lobbying is outlawed by sections 102, 103 and 105 of the Crimes Act $1961 .^{149}$ These sections deal with bribery directed towards Ministers of the Crown, members of Parliament and public officials, respectively. If one of these parties "corruptly accepts, or obtains, or agrees or offers to accept or attempts to obtain, any bribe for himself or herself or any other person in respect of any act done or omitted, or to be done or omitted, by him or her in his or her capacity" 150 then they are guilty of corruption and bribery under the Act. A bribe is defined as "any money, valuable consideration, office, or employment, or any benefit, whether direct or indirect." 151

In the unanimous 2011 Supreme Court ruling of Field $v$, William Young $\mathrm{J}$ espoused two overlapping bases for the presumption that "it is simply wrong to accept money... in return for what has been done in an official capacity." $" 152$ First, bribery creates an environment which tends to promote corruption. ${ }^{153}$ Second, the exchange of money for quid pro quo benefits distorts the decision-making process. ${ }^{154}$ It is clear that outright bribery is clear of the blurred line between ethical and unethical lobbying; for this reason it has earned a strong legislative response which enforces a blanket ban over bribery as a particular lobbying strategy. The nature of commonplace lobbying

\footnotetext{
${ }^{148}$ Hon Trevor Mallard "Lobbying and the government” (Four Winds Communication Seminar, Wellington, 25 November 2003).

${ }^{149}$ Conceptually, bribery is often classified as a - discouraged - form of lobbying. See Timothy Besley and Stephen Coate "Lobbying and Welfare in a Representative Democracy" (2001) 68 Rev Econ Stud 67 at 68 . It might be more accurate to describe the two actions as interchangeable tools, which are selected on the basis of the regulatory environment and the resources of the lobbyist; see Jakob Svensson "Eight Questions about Corruption" (2005) 19 J Econ Perspect 19 at 21.

${ }^{150}$ Crimes Act 1961, ss 102(1), 103(1) and 105(1).

${ }^{151}$ Crimes Act 1961, s 99.

${ }^{152}$ Field $v R$ [2012] 3 NZLR 1 at [59].

${ }^{153}$ Field $v R$ [2012] 3 NZLR 1 at [61].

${ }^{154}$ Field $v R$ [2012] 3 NZLR 1 at [62].
} 
interactions is much more subtle than out-and-out power-for-sale and thus is not regulated by the Crimes Act 1961. These provisions go much further than the recommendations of the OECD, but bribery is a particularly harmful form of lobbying and thus its criminalisation is rational.

\section{$2 \quad$ Electoral Act 1993 and political finance}

Political finance is an important tool for lobbyists. It allows them to use their clout which is often financially derived - to influence the passage of legislation and the determination of governmental decision-making processes. Almost all established democracies have enacted some form of regulation to govern the system of political finance. ${ }^{155}$ Approaches vary. Some states endorse a public funding scheme (which forces parties to draw from a pre-allocated fund for certain activities), some make public subsidies available (which are allocated on a range of bases, but usually with the intention of creating an equal electioneering environment), others require funding returns to be made to an auditing body (typically to increase transparency), but most use a combination of one or more of these techniques. ${ }^{156}$ In New Zealand, the Electoral Act 1993 defines two broad ways in which lobbyists can use their funds or the funds of their clients in the pursuit of political power: election expenses (campaign contributions and advertisements) and donations (towards parties and candidates).

The broad objective of political finance law is to increase political equality by reducing the degree to which wealth might unduly influence policy decisions. By taking meaningful steps towards reducing the disparity in political power between those who are wealthy and those who are not, governments ensure that political liberties "have real value to the people who have them.",157

It seems patently unlikely that third parties would contribute such vast sums towards political coffers without hoping to reap some benefit. That said, care must be taken to distinguish this expectation from a description which is analogous to bribery. Thirdparty political financing does not commonly produce situations whereby public powers are misused in exchange for private profit. The practice differs meaningfully from bribery in a number of crucial ways. Most essentially, there are no explicit quid pro quo conditions (such as an obligation for an MP to vote against a particular legislative proposal in exchange for cash) placed on the public official in question. Political funding is more appropriately viewed as a relationship building exercise. In this sense, the third-party contributes towards political coffers in the hope that it will give the group a greater deal of access to political actors at a later date. It is at this later date that the act of lobbying occurs. Prominent lobbying regulation academics William Luneburg and Thomas Susman dispute this distinction, pointing to the universality of reciprocity expectations and claiming that favours from lobbyists "have a tendency to increase access for the lobbyists or favourable consideration for legislative or executive action sought by them."158 Though rather cynical, Luneburg and Susman's argument appears to have merit. However, its strength is eroded by

\footnotetext{
${ }^{155}$ Magnus Ohman "Global Trends in the Regulation of Political Finance" (paper presented to IPSAECPR Joint Conference, University of Sao Paulo, Brazil, 16 February 2011) at 5.

${ }^{156}$ Magnus Ohman "Global Trends in the Regulation of Political Finance" (paper presented to IPSAECPR Joint Conference, University of Sao Paulo, Brazil, 16 February 2011) at 5.

${ }^{157}$ Cass R Sunstein "Political Equality and Unintended Consequences" (1994) 94 Colum L R 1390.

${ }^{158}$ William V Luneburg and Thomas M Susman "Lobbying Disclosure: A Recipe for Reform” (2006) $33 \mathrm{~J}$ Legis 32 at 46.
} 
another way in which political finance differs from bribery. Generally speaking, a significant donor will be known to the political recipient and thus the recipient will have a vague notion of the ways in which the donor would like to influence policymaking and decision-making processes. A bribe makes this notion explicit, because the benefactor typically asks for the exercise of a specific public power in exchange for the favour offered.

The definitions of lobbying used towards the outset of this paper support the above points of distinction. For example, the Encyclopædia Britannica approach considers lobbying to be "any attempt by individuals or private interest groups to influence the decisions of government". ${ }^{159}$ If the lobbyist does not make a request with respect to a government decision at the time it makes the donation then there is no possibility that their benefaction can achieve these aims. If follows that this action cannot rightly be seen as lobbying in its own right. Despite this, third-party political financing is still a part of the lobbying process - albeit a preliminary one - and as such is an appropriate area for analysis in the context of this paper. As with the other areas of law and convention canvassed in this chapter, this section assesses the interplay between political finance rules and lobbyists in New Zealand.

(a) Political finance law in New Zealand

Elections are important times for lobbyists. Candidates spend the run-up to elections consulting third parties for policy advice, ${ }^{160}$ and seeking indications of public sentiment from pressure groups (such as workers' unions). ${ }^{161}$ Lobbyists are intrinsically involved in each of these events, which provide them with privileged access to potential legislators. Electoral campaigns are extremely expensive, which allows lobbyists (and their clients) to offer essential financial assistance in the hope of cultivating a relationship with the party or candidate concerned.

Election campaigns are often subject to expenditure caps and disclosure requirements for third-party election financiers. Such law is implemented to reduce the differences in advertising exposure - and the influence which it brings - between wealthy and less wealthy political contestants. ${ }^{162}$ From a rights perspective, this might at first seem contradictory; it seems incongruous that the right to freedom of expression (such as the use of advertisement time on a television channel) might rationally be limited in order to guarantee the free expression of the electorate. However, proponents of thirdparty funding caps and disclosure regimes hold that "in a market-based society, virtually every form of communication involves some sort of monetary outlay."163 They argue that in order for fair elections to take place, the effects of economic inequality must be recognised and minimised. ${ }^{164}$ This principle is not without controversy and has been the subject of an enormous amount of academic discourse

\footnotetext{
159 "Lobbying” (2013) Encyclopædia Britannica

<http://www.britannica.com/EBchecked/topic/345407/lobbying>.

${ }^{160}$ Timothy Besley and Stephen Coate "Lobbying and Welfare in a Representative Democracy" (2001)

68 Rev of Econ Stud 67 at 69.

161 John M De Figueiredo "Lobbying and Information in Politics" (2002) 4 BAP 125 at 126.

162 Jessica A Levinson "The Original Sin of Campaign Finance Law: Why Buckley v Valeo is Wrong" (2013) 47 U Rich L Rev 881 at 882.

${ }_{163}$ Andrew Geddis Electoral Law in New Zealand (2007, Lexisnexis, Wellington) at [8.1].

${ }^{164}$ Electoral Commission Towards a Better Democracy (December 1986) at [8.28].
} 
and jurisprudence. ${ }^{165}$ The merits of these perspectives fall well outside the ambit of this paper.

In 1986 the Royal Commission on the Electoral System published its report. The Commission recommended that the incoming electoral legislation include rules around political finance in order to address a range of concerns. It stated that although it is "desirable that those interested in the political process raise and spend money to further their political objectives" ${ }^{166}$ wealth should not be used to prevent others from communicating their views, nor should it be used to disproportionate effect in securing the pursuit of certain political objectives, or put to "improper" use to distort political process. ${ }^{167}$ These recommendations culminated in a basic requirement that third-party advertising must be conducted in an accountable and authorised manner, ${ }^{168}$ and that campaign expenses must not exceed certain caps. ${ }^{169}$

In New Zealand, third-party financial backing has been the subject of intense debate, particularly since 2005 . Of principal concern since that time is the ability of powerful and wealthy third-party interests to donate to candidates and parties, and to contribute towards electoral advertisement expenses. ${ }^{170}$ This debate led to the assent of the controversial Electoral Finance Act 2007, its subsequent repeal 14 months later, and the introduction of alternative rules under the Electoral (Finance Reform and Advance Voting) Amendment Act 2010.

Those lobbyists who are considering contributing to electoral campaigns must be aware of these provisions and the conditions stipulated within the current Electoral Act 1993. The two forms of contribution regulated by the Electoral Act 1993 pertain to election campaign expenditure and donations. The modern equivalents of the electoral finance provisions of the Act are much more detailed and arguably more onerous that their original counterparts. The Act now imposes limitations on election expenses, advertising costs and promoter expenditure. It also regulates party and candidate donations. These measures have implications for lobbyists, and as a corollary must also factor in to any discussion surrounding the development of further lobbying regulation.

\section{(i) Campaign expenditure}

Third-party campaign expense contributions were placed under close public scrutiny in the aftermath of the 2005 General Election. Perhaps the most notable instance of controversy with respect to expense contributions was that caused by the campaigning efforts of the Exclusive Brethren Church. ${ }^{171}$ Similar controversy arose with respect to

\footnotetext{
${ }^{165}$ See generally Bradley Smith Unfree Speech: The Folly of Campaign Finance Reform (Princeton University Press, 2009); David M Primo and Jeffrey Milyo "Campaign Finance Laws and Political Efficacy: Evidence from the States" (2006) EconPapers <econpapers.repec.org>; Bradley Smith "Why Campaign Finance Reform Never Works” Wall Street Journal (online ed, New York, 19 March 1997) at A19.

${ }^{166}$ Electoral Commission Towards a Better Democracy (December 1986) at [8.2].

${ }^{167}$ Electoral Commission Towards a Better Democracy (December 1986) at [8.2].

${ }^{168}$ Electoral Act 1993 (as at 1993), s 221.

${ }^{169}$ Electoral Act 1993 (as at 1993), s 213 (2).

${ }^{170}$ Nicky Hager The Hollow Men: A Study in the Politics of Deception (Craig Potton Publishing, Nelson, 2006) at 238.

${ }^{171}$ Nicky Hager The Hollow Men: A Study in the Politics of Deception (Craig Potton Publishing, Nelson, 2006) at 238.
} 
campaign contributions made by trade unions and the racing industry. ${ }^{172}$ Different degrees of regulation apply to third-party backers based on the amount of money contributed.

All third party promoters must comply with a range of directives under the Electoral Act 1993. Third party promoters must register with the Electoral Commission if they intend to spend over $\$ 12,000$ on election advertising in the three months leading up to a General Election. In 2011, the General Election and Referendum saw 21 promoters register. ${ }^{173}$ The register is publically available and includes the name of the promoter (often an organisation or corporation), address, persons authorised to make the application (where the promoter is not an individual), names of persons occupying positions similar to directorship where the promoter (where the promoter is not an individual or a company) and names of trustees (where the promoter is a trust). ${ }^{174}$

In many cases contributors must include a promoter statement (including the funder's name and address) and written authorisation from the recommended party or candidate. ${ }^{175}$

Further to this, in the three month period prior to a general election, expenditure is capped with respect to both candidates and parties. Candidate expenditure is capped at $\$ 25,700$ for a general election and $\$ 51,300$ for by-election. ${ }^{176}$ Party expenditure is capped at $\$ 1,091,000$, in addition to $\$ 25,700$ for each electoral district contested by a candidate for the party. ${ }^{177}$ This is significant for lobbyists as it directly impacts the amount that third parties may spend on the campaigns of their targets. The cap of each group includes contributions made by candidates, party secretaries and registered promoters. $^{178}$

These provisions cover most of the characteristics outlined by the OECD as necessary for an effective lobbying regime. ${ }^{179}$ The transparency measures allow the public to gain some (admittedly superficial) understanding of some of the key aspects of the lobbying activity, thus partly meeting the criteria for "standards and procedures for disclosing information that covers key aspects of lobbying". 180 The financial thresholds and relevant regulations are well-defined, and the Electoral Commission actively provides further clarity by delivering advice in response to queries about proper interpretation of the Electoral Act $1993 .{ }^{181}$ The Commission also is responsible for investigating alleged breaches, and for referring these on to the Police. ${ }^{182}$

\footnotetext{
${ }^{172}$ Andrew Geddis "Rethinking the Funding of New Zealand's Election Campaigns" (2007) 3 Pol Q 3.

173 "Register of Promoters 2011 General Election and Referendum" (1 February 2013) New Zealand

Electoral Commission <http://www.elections.org.nz/events/past-events-0/2011-general-

election/parties-candidates-and-promoters-2011-general-election-1>.

${ }^{174}$ Electoral Act 1993, s 204L.

175 Electoral Act 1993, s 204E-H.

${ }^{176}$ Electoral Act 1993, s 205C (1).

${ }^{177}$ Electoral Act 1993, s 206C (1).

${ }^{178}$ Electoral Act 1993, s 205A, 206A.

${ }^{179}$ OECD Lobbyists, Governments and Public Trust, Volume 1: Increasing Transparency Through Legislation (OECD Publishing, 2009) at 11.

${ }^{180}$ OECD Lobbyists, Governments and Public Trust, Volume 1: Increasing Transparency Through Legislation (OECD Publishing, 2009) at 11.

${ }^{181}$ Mai Chen Public Law Toolbox (1st Edition, Lexisnexis, Wellington, 2012) at 141.

${ }^{182}$ Electoral Act 1993, s 205P.
} 
Two enforceable codes of conduct exist for lobbyists who contribute to election expenses: the Advertising Standards Authority Code of Ethics (pertaining to the honesty and accuracy of advertisements), and the Elections Programmes Code of Broadcasting Practice. The most directly relevant to "fostering a culture of integrity" 183 is the latter, which prevents lobbyists from broadcasting denigrations and misleading programmes, and requires a distinction to be clearly made between factual information and opinion or advocacy. ${ }^{184}$ For the purposes of a lobbying code of conduct, a range of deficiencies exist. For example, it does not require the disclosure of any conflict of interest. Another obvious issue is that it only applies to advertising (as opposed to broader lobbying activities) and only where these advertisements concern general elections or by-elections for members of the House of Representatives.

In short, the Electoral Act 1993 and its associated instruments provide moderate level of regulation over some types of lobbying activity. Of course, the foremost shortcomings are that these regulations only apply to the regulated period ${ }^{185}$ and only for those lobbying engagements where the lobbyist chooses to use campaign contributions as a mechanism to encourage favour.

\section{(ii) Donations}

Those lobbyists who directly contribute to the coffers of a political party or candidate face year-round regulation under the Electoral Act 1993. ${ }^{186}$ This is again on the muchdebated ideal that 'the particular uses to which 'political' money and resources are put should not themselves be unfair or likely to distort the proper working of a democracy." $" 187$

Without regulation, there is a greater potential for regular and damaging money-forpolicy transactions. ${ }^{188}$ The regulation of candidate expenditure in New Zealand dates back to $1895 .{ }^{189}$ Political donations have been under particularly hostile public scrutiny since 2005 . In the intervening years it has become evident that, for almost all the major parties, "a large amount of 'anonymous' and 'trust-funnelled' money [has] poured into their coffers. ${ }^{190}$ A range of accusations have been made about the legitimacy of these donations. ${ }^{191}$

\footnotetext{
${ }^{183}$ OECD Lobbyists, Governments and Public Trust, Volume 1: Increasing Transparency Through Legislation (OECD Publishing, 2009) at 11.

${ }^{184}$ Broadcasting Standards Authority Election Programmes Code of Broadcasting Practice (May 2011), Standards E1-4.

${ }^{185}$ Electoral Act 1993, s 3B.

${ }^{186}$ Electoral Act 1993 ss 207-210F.

${ }^{187}$ Electoral Commission Towards a Better Democracy (December 1986) at [8.2].

${ }^{188}$ Michael Pinto-Duschinsky "Financing Politics: A Global View" (2002) 13 J Democr 69 at 71.

189 "Story: Elections and Campaigns - Electoral Finance" (13 July 2012) Te Ara Encyclopaedia of New Zealand < http://www.teara.govt.nz/en/elections-and-campaigns/page-5>.

${ }^{190}$ Andrew Geddis "The Electoral (Finance Reform and Advance Voting) Amendment Bill" (2010) 6 Pol Q 3.

${ }^{191}$ Kevin List "Mallard Attacks National's Use of Trust Funds" (23 July 2005) Scoop: Independent News <http://www.scoop.co.nz/stories/HL0507/S00308.htm>; "Maori Party don't know who offered \$250,000” The New Zealand Herald (online ed, Auckland, 29 September 2006); “Winston Peters' Statement" The New Zealand Herald (online ed, Auckland, 25 July 2008); "Timeline: The NZ First donations saga" The New Zealand Herald (online ed, Auckland, 23 September 2008).
} 
Donors are subject to similar rules governing those applying to third-party electoral campaign expenditure. Donations are subject to a sliding scale of scrutiny (predominantly on the basis of the dollar amount contributed) under the Electoral Act 1993. Section 207(2) of the Act defines donations broadly, including cash, goods, or services of over $\$ 1,500$ to parties and $\$ 300$ to individual candidates. ${ }^{192}$

Donations to parties can be made anonymously if they amount to less than $\$ 1,500 .{ }^{193}$ There are a range of reasons why a donor might wish to keep his or her identity private, perhaps due to employment in the politically-neutral state sector, or some other occupation which requires a degree of political impartiality. ${ }^{194}$ Any donations exceeding this amount must be made by a donor who is identifiable by the recipient, or the amount in excess of $\$ 1,500$ must be given to the Electoral Commission. ${ }^{195}$ It is unlikely that a lobbyist would wish for his or her identity to be hidden from the recipient of a donation, because anonymity omits any possibility of the donation generating relationship capital with its recipient.

Overseas lobbyists are subject to requirements in the event that they wish to donate to a party or candidate. Those donors who live overseas and are not New Zealand citizens or registered electors, based overseas (for unincorporated bodies) or have been incorporated overseas (for bodies corporate) may not donate more than $\$ 1,500$ to a candidate or party in any given year. In addition to this cap, overseas donations are subject to similar disclosure requirements to their domestic counterparts. ${ }^{196}$

Details surrounding party donations totalling over $\$ 1,500$ are submitted in annual returns to the Electoral Commission. ${ }^{197}$ This information includes particulars to identify contributors and donors. ${ }^{198}$

Subpart 3 of the Electoral Act 1993 covers some of the criteria espoused by the OECD necessary to limit lobbying harms. ${ }^{199}$ It helps to identify the sources of heavyweight political donors, who presumably command more influence than lesser donors on account of their substantial financial power. By requiring the disclosure of contributors who make up a larger cumulative donation, the Electoral Act helps to ensure that sponsors cannot indirectly contribute in order to disguise their identities. ${ }^{200}$ A Crown Law opinion to the Electoral Commission Chief Executive Helena Catt in 2007 highlights the major failing in transparency surrounding lobbyists' ability to donate to parties; namely, that the trust funds may legally be used to circumvent disclosure requirements, because "there is no requirement to identify the source of the trust's funds." ${ }^{201}$ As with rules around election expenses, the intent of the lobbying activity may remain shrouded. Those making political donations are not required to adhere to a code of conduct.

\footnotetext{
192 Electoral Act 1993, s 207(2).

${ }^{193}$ Electoral Act 1993, 207(I).

${ }^{194}$ Mai Chen Public Law Toolbox (Lexisnexis, Wellington, 2012) at 149.

${ }^{195}$ Electoral Act 1993, s 207I(2).

${ }^{196}$ Electoral Act 1993, s 209(5).

${ }^{197}$ Electoral Act 1993210.

${ }^{198}$ Electoral Act 1993, ss 210(2)-(6).

${ }^{199}$ OECD Lobbyists, Governments and Public Trust, Volume 1: Increasing Transparency Through Legislation (OECD Publishing, 2009) at 11.

${ }^{200}$ Electoral Act 1993, 207C(2).

${ }^{201}$ Letter from Cheryl Gwyn (Deputy Solicitor-General) to Helena Catt (Chief Executive of the Electoral Commission) regarding anonymous donations to political parties (25 January 2007).
} 
In addition to these issues, the definition of "donations" is narrower than the consideration given by lobbyists in some arrangements. While the Electoral Act considers donations to include money and assets, it does not incorporate other forms of incentives such as the offer of future opportunities (e.g. lobbying firms suggesting prospective employment opportunities to government representatives). It also does not compensate for concerns expressed about how lobbyists can influence decisionmakers purely by virtue of a pre-existing relationship between the parties, thus negating the need for any compensation on the part of the lobbyist.

(b) Electoral Act 1993 conclusions

In some ways, New Zealand's current electoral finance regulatory framework is similar to the disclosure regime suggested under the Lobbying Disclosure Bill. Each instrument includes provisions which oblige third-party interests to disclose their identity in the interest of governmental integrity and public confidence. ${ }^{202}$ This is where the similarities end. Two strong distinctions emphasise this dissimilarity. The first is readily apparent; with the exception of annual political party donation returns, the provisions of the Electoral Act 1993 which pertain to campaign finance are only applicable during the regulated election period. The second difference is that - even in those situations where disclosure requirements are at their most severe under the Electoral Act 1993 - there is no robust mechanism to ensure that lobbyists adhere to a standard of ethics.

\section{$3 \quad$ Standing Orders of the House of Representatives 2011 and gifts}

There are a number of Standing Orders which govern aspects of lobbying activity in New Zealand. The Electoral Act 1993 deals with activity between lobbyists and candidates or parties, whereas Standing Orders deal with the lobbying activities which may have direct personal benefits for the targeted Member of the House.

Members are obliged to file annual returns to the Registrar of Pecuniary and Other Specified Interests of Members of Parliament. ${ }^{203}$ These returns must include all gifts received by parties other than those from family members, whose total market value exceeds $\$ 500$. "Gift" is intended to include hospitality. ${ }^{204}$ MPs must also divulge the details of any debts paid on their behalf that exceeded $\$ 500$. These disclosures must include the name of the benefactor. ${ }^{205}$

Additionally, MPs must also identify parties who contributed towards overseas travelling expenses (except when these have been contributed by the member, family, the Crown or other governmental organisations). ${ }^{206}$

Amongst other obligations, MPs must disclose any form of employment income received outside of Parliament, the name of each company in which the member is a director or holds more than 5 per cent of voting rights, other pecuniary interests in

\footnotetext{
${ }^{202}$ Lobbying Disclosure Bill 2012 (15-1) (explanatory note), cl 7.

${ }^{203}$ Standing Orders of the House of Representatives 2011, Appendix B: Pecuniary and other specified interests, 4.

${ }^{204}$ Standing Orders of the House of Representatives 2011, Appendix B: Pecuniary and other specified interests, 8(3)(a).

${ }^{205}$ Standing Orders of the House of Representatives 2011, Appendix B: Pecuniary and other specified interests, 8(b), (c).

${ }^{206}$ Standing Orders of the House of Representatives 2011, Appendix B: Pecuniary and other specified interests, 8 .
} 
businesses and companies and the names of trusts for whom the MP is a beneficiary or trustee. ${ }^{207}$ While the true purpose of these rules is to avoid conflicts of interest for MPs, they also prevent lobbyists from using the outside interests of MPs as leverage.

Some aspects of the Standing Orders appear to contribute towards the OECD principles for effective lobbying regulations. However, inefficiencies in the implementation of these rules mean that the Standing Orders only contribute towards the OECD principles in a cursory way. Gift-giving may also be distinguished from true lobbying activity, which means that those relevant Standing Orders would not necessarily have direct implications for potential lobbying legislation.

(a) Regulatory strength

The most evident difference between the OECD requirements and the Standing Orders is that the latter lacks legal enforceability. ${ }^{208}$ Where investigations indicate serious breaches the Registrar of Pecuniary Interests of Members of Parliament may report it to the House of Representatives. ${ }^{209}$ Minor breaches may be resolved by the Registrar requiring the member to amend his or her return. Neither of these provisions have serious repercussions beyond political consequences. As is the case with political donations, MPs have been caught out apparently using trusts to circumvent the identification of contributors. ${ }^{210}$

At no point are gift-givers or recipients obliged to disclose the intention of the gift. This is despite the common feature of a reciprocity expectation in political giftgiving; ${ }^{211}$ "studies have shown [that] the reciprocity rule is pervasive in human culture... despite their denials to the contrary, politicians are no less subject to its sovereignty than the rest of us." 212 This weakens the effectiveness of the transparency that would otherwise be available as a result of the Standing Orders. For example, in 2011 Hon Hekia Parata (then-Minister of Energy and Resources) received free tickets to Rugby World Cup games from NZ Petroleum and Minerals, NZ Oil and Gas and international oil and gas company OMV. ${ }^{213}$ Without a provision to require disclosure of the benefactor's intent, it is impossible to know what specific objectives these major fossil-fuel companies hoped to accomplish with the Minister of Energy and Resources. It is patently unlikely that these gifts affected Hon Hekia Parata's impartiality or integrity. However, the receipt of gifts from major corporate players within the ambit of the Minister's portfolio may appear untoward and thus damaging to public confidence in the integrity of governmental decision-making processes. Of course, a fundamental problem with this conceptualisation of political gift-giving is

\footnotetext{
${ }^{207}$ Standing Orders of the House of Representatives 2011, Appendix B: Pecuniary and other specified interests, 8(1)(d).

${ }^{208}$ Standing Orders of the House of Representatives 2011, Committee Review of Standing Orders (September 2011) at 27.

${ }^{209}$ Standing Orders of the House of Representatives 2011, Appendix B: Pecuniary and other specified interests, 16(8).

${ }^{210}$ Patrick Gower "SFO head says MPs were being mislead" The New Zealand Herald (online ed, Auckland, 23 September 2008).

${ }^{211}$ Nubia Evertson "Political Corruption and Electoral Funding: A Cross-National Analysis" (2013) 21 International Crim Justice Rev 75 at 76.

${ }^{212}$ William V Luneburg and Thomas M Susman "Lobbying Disclosure: A Recipe for Reform” (2006) $33 \mathrm{~J}$ Legis 32 at 46.

${ }^{213}$ Claire Trevett "MPs lapped up RWC tickets from corporates" The New Zealand Herald (online ed, Auckland, 24 May 2012); "Register of Pecuniary and Other Specified Interests of Members of Parliament: Summary of annual returns as at 31 January 2012” [2008-2011] XVII AJHR J.7 at 45.
} 
that an obligation to disclose intent is essentially a self-incriminating admittance of bribery. Instead, gift-giving by lobbyists is more appropriately viewed as an attempt to build relationship capital as opposed to an exchange of public powers for private goods. This mirrors the approach adopted in earlier in this chapter with respect to campaign donations. It must suffice to surmise that while the lack of transparency surrounding the intent of gift-givers may be less than ideal, the alternative disclosure - is unworkable.

(b) Definitional issues

Problems abound about the meaning of "gift". For example, recent concerns have been raised as to whether a discount of over $\$ 500$ received by an MP triggers a disclosure obligation. The Registrar advised that no disclosure was necessary, because the purchased item itself was not a gift to the member. ${ }^{214}$

Another problematic provision of the Standing Orders relates to interest-rate negotiation on debts held by MPs. Earlier rules required MPs to disclose details to identify debt arrangements where members had received a favourable interest rate (i.e. less than the market interest rate) in debts over $\$ 50,000$. Following uncertainty about the application of these rules, the Standing Order Committee recommended an amendment to restrict the disclosure of these arrangements where the lender is a bank or other traditional lending institute. ${ }^{215}$ This was incorporated into the 2011 Standing Orders. ${ }^{216}$ One potential outcome of this could be that these excluded lenders could offer significantly advantageous rates to MPs with respect to debts such as mortgages without the need for incriminating disclosures. Banks conduct extensive lobbying activities and this particular avenue for influence is now unregulated.

(c) Scope

Further to these concerns, the disclosure of financial interests are only obligatory in relation to the passage of law; "if related to asking a question in the House, it would be optional... for an MP to declare a financial interest."217

Finally, the rules contained within the Standing Orders of the House of Representatives cover only those members and committees which fall under its auspices. The harms of lobbying activity result from activity carried out all over the political hierarchy, including officials of ministries, thus severely limiting the Standing Orders from performing any major part in the regulation of lobbyists in New Zealand.

(d) Conclusions

The OECD recommendations used as a basic indicator of comprehensive lobbying regulations throughout this chapter include standards to address public concerns, legislation which adequately defines lobbying actors and activities, standards for disclosing key information about lobbying activity, enforceable codes of conduct and

\footnotetext{
${ }^{214}$ Standing Orders Committee "Review of Standing Orders" [2008-2011] III AJHR I.18B at 58.

${ }^{215}$ S Standing Orders Committee "Review of Standing Orders" [2008-2011] III AJHR I.18B at 57.

${ }^{216}$ Standing Orders of the House of Representatives 2011, Appendix B: Pecuniary and other specified interests, 5(4).

${ }^{217}$ Sue Kedgley "Let's prevent our own lobbying scandal" The New Zealand Herald (online ed, Auckland, 27 June 2013).
} 
strategies to secure compliance. ${ }^{218}$ Those Standing Orders that pertain to the pecuniary interests of MPs overlap slightly with these recommendations. The giving of gifts can be meaningfully distinguished from lobbying activity (as the former lacks the requisite request for reciprocation) but must be viewed as part of the lobbying process, and thus is an appropriate area for regulation. It is clear that the Standing Orders lack the scope and robustness of comprehensive lobbying legislation, but these provisions are compatible with, and would contribute towards, the development of such a law.

The Official Information Act 1982 (OIA) is New Zealand's most accessible transparency law. It empowers ordinary citizens with the ability to request almost any information held by governmental departments, Ministers for the Crown and some organisations. ${ }^{219}$ It is also the only current avenue by which most interested parties are able to discover information about lobbying activity directed at public office holders. As legislative instrument to enable public access to information held by government, the OIA is inherently incapable of fulfilling all of the various aspects of a lobbying regime. Of the OECD recommendations, it has the potential to fill two: those which pertain to standards and rules to address public concerns and conform to the sociopolitical and legal context, and standards and procedures for disclosing information that covers key aspects of lobbying. A brief analysis of the merits of the OIA as a mechanism for lobbying transparency is warranted, as any potentially overlapping functions must be considered in the drafting of targeted lobbying legislation.

(a) Analysis

(i) Accessibility

A fundamental distinction between the OIA and OECD-compliant lobbying legislation lies in the fact that the former does not specifically compile information about lobbying activity. The latter requires active disclosure by lobbyists, which increases the amount of information available to the public. This is in part because the breadth and scope of information covered by the Official Information Act 1982 is such that a compilation of all relevant materials is utterly unrealistic. Disclosed lobbyists and lobbying activity, by contrast, would be listed in a database, in both online and hard-copy formats. ${ }^{220}$ This fundamental distinction would be magnified at the information-seeker level, because successful information-seekers using the Official Information Act 1982 must be equipped with skills and comprehension above that expected from a searchable database.

Under the Official Information Act 1982, information seekers must take care to define the scope of information sought. By necessity, requests must be sufficiently narrow. Without this requirement, requests could easily overburden the departments and offices subject to its provisions. It follows that requesters should have a working knowledge of the processes and demands of the OIA process. They must know to whom the request should be directed, the capacity in which the department, Minister

\footnotetext{
${ }^{218}$ OECD Lobbyists, Governments and Public Trust, Volume 1: Increasing Transparency Through Legislation (OECD Publishing, 2009) at 11.

219 Official Information Act 1982, Schedule 1; Ombudsmen Act 1975, Schedule 1, Parts 1, 2.

${ }^{220}$ This information is usually stored in a publically-accessible database. See Part II of this thesis for more detail.
} 
or organisation holds the information (for example, which portfolio should a Minister consider if he or she is asked for information).

\section{(ii) Exceptions}

Significantly, the information request can be refused on the basis of four classes of reasons enumerated by the Official Information Act $1982 .{ }^{221}$ Conclusive reasons for withholding information pertain to matters of national security, foreign affairs, justice, individual safety and economic stability. ${ }^{222}$ The less-robust "other reasons" for withholding official information encompass a diverse spread of themes including privacy, commercial interests, constitutional considerations, improper gain or advantage and prejudice to public health or economic wellbeing. ${ }^{223}$ These defences for non-disclosure can be problematic for inadequately drafted requests. This can be particularly true of requests made with respect to lobbying activity as it often touches on these themes.

It is reasonable to assume that Section 18(f) might play a strong role in inhibiting the release of information about lobbying activity. It states that a request can be refused on the basis that the "information requested cannot be made available without substantial collation or research". ${ }^{224}$ From the perspective of the information-gatherer, the standards imposed by most lobbying disclosure legislation are burdensome. Those interested in Canadian lobbying activity are directed by the Office of the Commissioner of Lobbying online database to search within a 12-month parameter. ${ }^{225}$ An official information request of a similar nature would require an utterly unreasonable amount of collation, which would inevitably put the request foul of Section 18(f). The sheer number of lobbyists and the degree and variety of information required about them and their activities would be an insurmountable task for the office concerned.

\section{(iii) Errors and omissions}

Official information requests are regularly mishandled by the information-holder. This adds significant delay and uncertainty to the retrieval process. Section 28(3) of the Official Information Act 1982 empowers information seekers to request that the Ombudsmen investigate and review decisions made by information holders. The most recent annual report from the Office of the Ombudsman recorded 1,236 complaints made about official information requests. ${ }^{226}$ Administrative deficiencies were identified in $18 \%$ of all cases formally investigated. The Ombudsmen are an effective compliance tool, but it requires expertise which would not be necessary under a lobbying disclosure regime.

(iv) Scope

\footnotetext{
${ }^{221}$ Official Information Act 1982, ss 6-9.

${ }^{222}$ Official Information Act 1982, s 6.

${ }^{223}$ Official Information Act 1982, s 9.

${ }^{224}$ Official Information Act 1982, s 18(f).

225 "12-Month Lobbying Activity Search" (09 September 2013) Office of the Commissioner of Lobbying of Canada <https://ocl-cal.gc.ca/app/secure/orl//rrs/do/clntSmmrySrch>.

${ }^{226}$ Annual Report of the Ombudsmen: $2011 / 2012$ (The Office of the Ombudsman, A.3, 30 June 2012) at 5 .
} 
As with the other instruments and laws studied as part of this analysis, the Official Information Act 1982 deals only with a specific category of lobbying, which dramatically minimises its use. It does not apply to lobbying activity where the target of the activity was an MP. Members' diaries, correspondence and other materials which belong to an MP acting in that capacity are not considered to be official information. ${ }^{227}$ This means it is possible that "Ministers can also decline to provide information about meetings they have in their role as an MP, as opposed to in their role as Minister."228

(b) Requests for information about lobbying under the Official Information Act 1982

Due to these fundamental differences between the two modes of information gathering, it is unlikely that the Official Information Act 1982 is capable of performing the same function as those described by the OECD. The results of two official information requests help to clarify the accuracy of this assertion.

The Honourable Gerry Brownlee, Minister for Canterbury Earthquake Recovery, Earthquake Commission and Transport, and the Honourable John Banks, Associate Minister of Commerce and Education, and Minister for Regulatory Reform and Small Business received the following requests in July 2013. The content of the request was modelled closely on the requirements of the Lobbying Disclosure Bill:

Dear [Minister],

I wish to test an assertion often made in opposition to the Lobbying Disclosure Bill; specifically, that a register of lobbyists is superfluous to the information already freely available under the Official Information Act 1982.

In accordance with my objective, I would like to request all information held (including Ministerial Diaries) in relation to:

All instances between 1-31 May 2013 where the Minister met or otherwise conversed with parties who engaged in lobbying activity.

For the purposes of this request, "lobbying activity" should be considered to mean:

Communication between the minister and any party (the lobbyist) who is paid to represent the views of any person, company, firm or organisation (the client), where the principle purpose of the communication was to convey the client party's view on the state or development of:

Any legislative proposal, Bill, Act, regulation, amendment, policy, programme, or the awarding of grants, funding, contracts, or any other financial benefit which falls under the auspices of the Government of New Zealand to allocate.

For each instance of "lobbying activity", I would like to know:
The name and business address of the lobbyist
The name and business address of the represented client
The subject matter(s) discussed

\footnotetext{
${ }^{227}$ Official Information Act 1982, s 2(1).

${ }^{228}$ Gareth Richards "Lifting the Lid on Lobbying" NZLawyer Magazine (online ed, Auckland, 1 June 2012).
} 
- $\quad$ The name and business address of the client and any person or body that controls or directs the activities of the client and has a direct interest in the outcome of the activities undertaken on behalf of the client

- Where the client is a company, the name and business address of each subsidiary of the company that has a direct interest in the outcome of the activities undertaken on behalf of the client

- Where the client is a company that is a subsidiary of another company, the name and business address of that other company

Where the client is a coalition, the name and address of each person or body that is a member of that coalition

Particulars to identify the subject-matter in respect of which the lobbying activity was undertaken

Particulars to identify the communication technique used to communicate with a public office holder (e.g.: telephone conversation, internet conference etc.)

I appreciate that this is a significant request, involving multiple parties, events and resources. I would be grateful for efforts made to provide the requested information. Please contact me if you have any queries.

(c) Results and evaluation

The requests were made on 11 July 2013, and responses were received within the 20 working days mandated by the Act. The window of time with which the lobbying official information requests were concerned was limited to a single month. This is a much smaller window of time than what would be available under a disclosure regime, but a request of a broader nature was more likely to be refused under Section 18(f) of the Act.

Unsurprisingly, the information requests yielded far less material than that which the OECD believes would ideally be available in order to "cover key aspects of lobbying such as its intent, beneficiaries and targets". ${ }^{229}$ In total, two instances of lobbying activity were disclosed, and neither of these instances of lobbying activity were accompanied by the recommended degree of information.

The Hon Gerry Brownlee rejected the request outright, citing section 18(f) of the Official Information Act 1982. The Minister explained that for each instance of potential lobbying activity, officials would need to determine the capacity in which the Minister attended and whether the instance qualifies as "lobbying activity" with reference to the Bill. ${ }^{230}$

Both parties relied upon Section 18(g) of the Official Information Act 1982, which allows requests to be refused on the basis that the information is not held by the party who is the subject of the request, provided that the subject has no grounds for believing that the information is held by or more closely connected with another department, Minister, organisation or local authority. ${ }^{231}$ The Hon Gerry Brownlee specified "the names, addresses, the company names or their subsidiary or coalition

\footnotetext{
${ }^{229}$ OECD Lobbyists, Governments and Public Trust, Volume 1: Increasing Transparency Through Legislation (OECD Publishing, 2009) at 11.

${ }^{230}$ Email from Office of Hon Gerry Brownlee to Liam Williams regarding communications with lobbyists (8 August 2013) (Obtained under Official Information Act 1982 Request to Office of Hon Gerry Brownlee).

${ }^{231}$ Official Information Act 1982, ss18(f)(i)-(ii).
} 
arrangements",232 as topics which his office did not retain information about. The Hon John Banks simply stated, "[m]ost of the information... requested is not held by this office". Despite this, the latter Minister provided information about two instances of lobbying activity (from 10 and 15 of May 2013). The disclosed instances were accompanied by the name of the lobbyist, the name of the client, the date that the lobbying took place and the method of communication employed. The Hon John Banks also provided some particulars to identify the subject matter in respect of which the lobbying was undertaken ("discuss the Employment Relations Amendment Bill" and "small business"), but this was not comparable to common disclosure requirements in terms of the level of specificity given.

\section{B Conclusion - A case for an additional public law tool?}

It is clear that existing measures are not capable of meaningful or comprehensive utility as tools to regulate lobbying in New Zealand. This is in large part due to the fact that the available tools were not specifically designed to apply to lobbying. The practice is a broad and multifaceted attribute that is common to all democratic government. The determination of an effective regulatory response would demand a thorough analysis of the varied forms of lobbying.

Existing legal and conventional mechanisms have failed to rein-in the damage caused by either of the harms identified in Chapter II, and do not appear to meet any of the basic functions of lobbying law such as those outlined by the OECD. There appears to be a sound basis for the introduction of some form of regulation. The following chapters critically appraise the various avenues open for regulation, considering how best to minimise the dual harms of unethical lobbying whilst legitimising and promoting lobbying activity as a valid and essential aspect of participatory governance.

\footnotetext{
${ }^{232}$ Email from Office of Hon Gerry Brownlee to Liam Williams regarding communications with lobbyists (8 August 2013) (Obtained under Official Information Act 1982 Request to Office of Hon Gerry Brownlee).
} 


\section{PART TWO - REGULATING LOBBYISTS}

\section{Registering Lobbyists and Recording Lobbying Activity}

The modus operandi for states interested in increasing the transparency of lobbying is to implement a register of lobbyists. The scope of register legislation varies greatly. The register proposed in the Lobbying Disclosure Bill was its weakest point. ${ }^{233}$ It poorly defined the parties to which the law was to be subject and imposed an unnecessarily complex and hefty bureaucratic burden. ${ }^{234}$

This part addresses the deficiencies in the register proposed in the Lobbying Disclosure Bill. Three central issues are engaged. This chapter outlines the main characteristics of lobbyists' registers and explains the concerns raised about the register contained in the Bill. Chapters V and VI propose more appropriate methods for defining "lobbyists" and those with whom lobbying activity should trigger registration obligations. Chapter VII considers the procedural burdens imposed by the register of the Bill and suggests alternatives which could achieve greater effect with reduced compliance costs.

\section{A Registers}

Common to all registers is the collection and publication of certain information. This information is gathered from registered lobbyists, and typically includes information to identify who they are, who they are lobbying for, the subject of the lobbying activity and which method of communication is being employed by the lobbyists. These registers are made publically available and searchable, mostly on the internet.

In 1946, the United States Congress enacted the world's first legislative scheme specifically designed to regulate lobbying. The genesis of lobbying regulation began with the Federal Regulation of Lobbying Act (FRLA), enacted by the United States Congress in 1946. Along with FRLA came a rudimentary lobbyists' register, the first of its kind to be passed into law. ${ }^{235}$ Among its novel provisions was a stipulation that every person who receives compensation for efforts made to influence the status of legislation before Congress must: ${ }^{236}$

register with the Clerk of the House of Representatives and the Secretary of the Senate and shall give to those officers in writing and under oath, his name and business address, the name and business address of the person by whom he is employed, and in whose interest he appears or works, the duration of such employment, how much he is paid and is to receive, by whom he is paid or is to be paid, how much he is to be paid for expenses, and what expenses are to be included.

\footnotetext{
${ }^{233}$ Lobbying Disclosure Bill 2012 (15-1), cls 6, 7.

${ }^{234}$ Lobbying Disclosure Bill 2012 (15-1) (select committee report) at 5.

${ }^{235}$ Although Bills to regulate lobbying were first put before Congress in 1907. See Belle Zeller "The

Federal Regulation of Lobbying Act” (1948) 42 Am Polit Sci Rev 239 at 241.

${ }^{236}$ Federal Regulation of Lobbying Act Ch 753, 60 Stat 841 (1946).
} 
Though noble in intent, the first lobbyists' register was fraught with weaknesses. ${ }^{237}$ Many simply ignored the legislation; in 1991, of the 13,500 lobbyists listed in the Washington Representatives Phonebook, only 3,700 had registered. ${ }^{238}$

Despite early difficulties, lobbying registers persist in the United States at both the federal and state level. Several parts of the United States, such as California, ${ }^{239}$ have imposed their own registers. The United States federal register is empowered by the Lobbying Disclosure Act $1995 .{ }^{240}$ Canada also has a mandatory legislative register, ${ }^{241}$ and a Bill currently before the Parliament of Ireland would be to a similar effect. ${ }^{242}$ The European Union has a voluntary register, ${ }^{243}$ as does France ${ }^{244}$ and Germany. ${ }^{245}$ Australia has a register, though it lacks a legislative foundation. ${ }^{246}$ Legislative registers exist in Poland ${ }^{247}$ and Austria, ${ }^{248}$ though these are in their infancy and thus have an array of deficiencies. Since 2005, eight countries have enacted lobbying registers. $^{249}$

\section{$B \quad$ The register of the Lobbying Disclosure Bill}

The failed Lobbying Disclosure Bill intended to introduce a register as the mechanism by which it was to increase transparency in lobbying activities. Some elements of the register had significant shortcomings, which eventually formed the basis on which it was rejected. This section describes these criticisms, for which Chapters 5, 6 and 7 offer a number of solutions.

\section{$1 \quad$ Definitional problems}

The Bill struggled to adequately define the terms "lobbyist" and "lobbying activity". ${ }^{250}$ These definitional issues presented challenges to the Bill's efficacy, which is the focus of the present chapter. This definitional issue was compounded by alleged human rights limitations, which are discussed in Chapter $\mathrm{X}$ of this paper.

\footnotetext{
${ }^{237}$ Steven A Browne "The Constitutionality of Lobby Reform: Implicating Associational Privacy and the Right to Petition the Government" (1995) 4 Wm \& Mary Bill Rts J 717 at 719; Brian W Schoeneman "The Scarlet L: Have Recent Developments in Lobbying Regulation Gone too Far?" (2011) 60 Cath U L Rev 505 at 516.

238 "Blinding the Waste Watchers" Gainesville Sun (10A, Florida, 28 March 1995).

${ }^{239}$ Cal Gov Code, title 9 \$ 86100-86300.

${ }^{240}$ Lobbying Disclosure Act 19952 USC $§ 1601-1614$.

${ }^{241}$ Lobbying Act RSC 1985 c44.

${ }^{242}$ Government Reform Unit "Regulation of Lobbying Legislation - Policy Proposals" (April 2013)

Department of Public Expenditure and Reform <http://per.gov.ie/wp-content/uploads/Summary-PolicyProposals.pdf $>$.

${ }^{243}$ Interinstitutional Agreement 2291/2010 on a Common Transparency Register [2009] OJ C 271 E.

${ }^{244}$ These rules are based on M Chrisophe Sirugue Président de la délégation chargée des représentants d'intérêts et des groupes d'études, au nom du groupe de travail sur les lobbies à l'Assemblée nationale (27 February 2013).

${ }^{245}$ Karsten Ronit and Volker Schneidher "The Strange Case of Regulating Lobbying in Germany" (1998) 51 Parl Aff 559 at 562.

246 (Au) Lobbying Code of Conduct.

247 Act on Legislative and Regulatory Lobbying 2006 (Pl).

248 (At) Lobbying and Advocacy Transparency Law 2012, s3.

249 "Fighting Corruption in the Public Sector: Lobbying" (June 2013) OECD

<http://www.oecd.org/gov/ethics/lobbying.htm>.

${ }^{250}$ Lobbying Disclosure Bill 2012 (15-1) (select committee report) at 3.
} 
The Lobbying Disclosure Bill defined lobbyists as parties who, "for payment, on behalf of any person... communicate with any public office holder" ${ }^{251}$ with respect to a number of broad topics. Concerns were raised by the Attorney-General that "payment" could easily be construed in such a way as to make the definition untenably broad. It could include "people working for or owning shares in an incorporated farm or small business", ${ }^{252}$ that decide to send a one-off email to their local MP. The Bill was strongly criticised for failing to exclude ordinary conversations between public officials and members of the public in its first reading ${ }^{253}$ and throughout the select committee process. $^{254}$

The Bill included a number of pragmatic exceptions for persons acting in their official capacity. MPs, public service employees, local authority employees, diplomatic agents, consular officers and official representatives of foreign governments were granted an exemption from falling into the lobbyist category. ${ }^{255}$ Such exceptions are an obvious necessity. A failure to include them could impede open communication between government actors. These exceptions did not go far enough; the Government Administration Committee expressed concerns that parties such as the parliamentary services would still be captured by the Bill's lobbyist definition, thus incurring unnecessary registration and disclosure requirements. ${ }^{256}$ A Supplementary Order Paper was proposed by Charles Chuavel, which attempted to provide an amended, exhaustive list of exemptions. ${ }^{257}$

\section{$2 \quad$ Public office holders}

The Lobbying Disclosure Bill did not offer a satisfactory definition of who should be considered a "public office holder" for the purposes of the law. This definition is significant, as lobbying activity with a public office holder would incur registration requirements. Both lobbyists and their targets must understand their obligations under the law. Evidence of this difficulty can be seen in apparent contradictions within the Bill itself. Clause 3 claims that the purpose of the legislation is to "increase the transparency of decision making by executive government". ${ }^{258}$ However, Clause 7(2) states that registration requirements are triggered where the targets are "public office holders", ${ }^{259}$ who are defined in Clause 4 as: ${ }^{260}$

Members of Parliament and any person employed in, or who works under a contract for services for, or who is working on secondment to, a member's office and for the avoidance of doubt Includes a Minister of the Crown and any person employed or working in a Minister's office.

\footnotetext{
${ }^{251}$ Lobbying Disclosure Bill 2012 (15-1), cl 7(2).

${ }^{252}$ Lobbying Regimes: An Outline (Parliamentary Library, Research Paper 12/04, April 2012) at 2.

253 (25 July 2012) 682 NZPD at 3962, 3964, 3965, 3967.

${ }^{254}$ Chen Palmer New Zealand Public and Employment Law Specialists "Submission to the

Government Administration Committee on the Lobbying Disclosure Bill" (17 October 2012) at 6; Maxim Institute "Submission on Lobbying Disclosure Bill" (5 October 2012) at 2: Human Rights Commission "Re: Lobbying Disclosure Bill" (5 October 2012) at 5.

${ }^{255}$ Lobbying Disclosure Bill 2012 (15-1), cl (7)(6).

${ }^{256}$ Lobbying Disclosure Bill 2012 (15-1) (select committee report) at 3.

${ }^{257}$ Supplementary Order Paper 2012 (76) Lobbying Disclosure Bill 2012 (15-1), cl 7(6).

${ }^{258}$ Lobbying Disclosure Bill 2012 (15-1), cl 3 (emphasis added).

${ }^{259}$ Lobbying Disclosure Bill 2012 (15-1), cl 7(2)(a).

${ }^{260}$ Lobbying Disclosure Bill 2012 (15-1), cl 4.
} 
The select committee submission made by public and employment law specialists Chen Palmer drew attention to another flaw in the Bill. They noted that communications with public service officials was not included as registerable activity under the bill. Due to the influence public service officials have with executive government, "the omission of communication with such officials by lobbyists would represent a significant 'loophole' for lobbyists, and may encourage the behaviour which the Bill aims to prevent.",261

Registration and disclosure

A number of submissions made on the Bill raised concerns about its universal approach to lobbying activity. The Bill, unlike some of its international counterparts, intended to charge all relevant lobbyists with the same registration and disclosure obligations. ${ }^{262}$ Some submitters felt that the Bill should vary the requirements expected of different lobbyists. Organisations including Amnesty International Aotearoa New Zealand, the New Zealand Disability Support Network and the Service and Food Workers Union Nga Ringa Tota recommended that professional lobbyists should be subject to more onerous requirements than NGOs and trade unions. ${ }^{263}$ Two arguments were made in favour of this distinction: professional lobbyists are more deserving of intensive scrutiny than NGOs and not-for-profits with respect to lobbying activity due to their increase financial clout, and NGOs and not-for-profits lack the resources and expertise to ensure compliance with a lobbyists' register.

\section{Conclusion}

The faults of the Lobbying Disclosure Bill's register do not negate the possibility of the implementation of a similar, more effective regime in New Zealand. Lobbyist registers are variable. Between jurisdictions, there are distinctions between which lobbyists and what types of activities incur registration requirements, and what degree of information these requirements entail. ${ }^{264}$ Registers must be tailored to reflect the nature of lobbying practices and the human rights instruments specific to the jurisdiction in which they operate.

\footnotetext{
${ }^{261}$ Chen Palmer New Zealand Public and Employment Law Specialists "Submission to the Government Administration Committee on the Lobbying Disclosure Bill" (17 October 2012) at [25].

${ }^{262}$ Compare Lobbying Disclosure Bill 2012 (15-1) cl 7 with Lobbying Act RSC 1985 c44, ss5 (Consultant Lobbyists), 7 (In-House Lobbyists (Corporations and Organisations)).

${ }^{263}$ Amnesty International Aotearoa New Zealand "Submission to the Government Administration Select Committee on the Lobbying Disclosure Bill" at [4.1]; New Zealand Disability Support Network "Re: Lobbying Disclosure Bill: The New Zealand Disability Support Network Submission" at 2; Service and Food Workers Union Nga Ringa Tota "Submission to the Government Administration Select Committee on the Lobbying Disclosure Bill" at [3].

${ }^{264}$ Lobbying Regimes: An Outline (Parliamentary Library, Research Paper 12/04, April 2012) at 3.
} 


\section{Who Must Register? Defining "Lobbyists" and "Lobbying Activity"}

Lobbying registration requirements impose a notable burden on many of the actors in everyday political interaction. It follows that the regulations that apply must define the intended target of its provisions with specificity and clarity to allow for straightforward interpretation. Unfortunately, such legislation frequently falls short of achieving this objective. Furthermore, approaches taken in different jurisdictions have consistently struggled to create legislative definitions which cover the target lobbyists while also avoiding the capture of other types of lobbyists.

As noted in Chapter I, the dictionary form of "lobbying" or "lobbyist" presents a much broader definition of the activity than that which is commonly treated by legislation and public perception. Given the variety of forms that lobbyists take - and the corresponding range of extents to which they might appropriately be required to register - it is unsurprising that there is little consistency between approaches to determining which lobbyists to regulate. A number of principles dictate the way in which the target of lobbying legislation is determined. Most evidently, the way that registerable lobbying is defined must effectively capture those lobbyists who participate in unethical or otherwise damaging lobbying activity. This requires drafters to be intimately familiar with the types of lobbying which occur within the jurisdiction concerned, and the different extents to which these require regulation. A register must place onuses which accurately reflect the context to which it is to be introduced. The scope of the definitional provisions must also be drafted with reference to the local legal framework. Registers should not require disclosure from lobbyists whose activities are already governed by another effective public law tool. $^{265}$

Clarity is possibly the most essential ingredient in the formulation of "lobbyist" for the purposes of the law. Non-lobbyists and those lobbyists who fall outside the ambit of the regulation must know that they are not subject to its provisions. Additionally, clarity is necessary in those states where delineations are made between different types of lobbyists (e.g. between in-house and consultant lobbyists). If poorly drafted, the practical application of these categories can cause confusion, or a fear that the lobbyist will improperly interpret the provisions of the register. One consequence of this scenario could be that lobbyists (or their clients) would refrain from lobbying in order to avoid the risk of incurring penalties for non-compliance. It is likely that this would mean a resultant drop in civic engagement and in the benefits which lobbying can provide.

This chapter involves a comparative analysis of the relevant lobbyist register provisions from Canada, the United States and Australia. The Canadian Lobbying Act 1985 served as the inspiration of the Lobbying Disclosure Bill and thus has a rightful place in this analysis. The United States has the oldest lobbying regulations in the world, and thus presumably has valuable insight to offer for similar attempts in New Zealand. The Australian register has a number of characteristics which make it

${ }^{265}$ Mai Chen Public Law Toolbox (Lexisnexis, Wellington, 2012) at 41. 
distinct from the other two states, which provides the analysis with a degree of contrast.

This chapter suggests a number of alterations to the provisions suggested in the Lobbying Disclosure Bill. These suggested provisions could more clearly articulate criteria to identify which lobbyists and lobbying activities would fall under the jurisdiction of the Bill, thus avoiding the capture of unintended targets.

\section{B Defining "lobbying”-International approaches at a glance \\ $1 \quad$ Federal lobbyists in Canada}

(a) Context

The 2008 Lobbying Act amendments and associated regulations are the most recent in a string of regulatory developments in Canada which have spanned over two decades. Although 19 Private Members' bills had been tabled in the House of Commons between 1969 and 1985 in an attempt to broach the issue, ${ }^{266}$ the first lobbying regulations were not passed into law until the Lobbyists Registration Act (LRA) in 1989. ${ }^{267}$ It was passed as a result of a range of reforms introduced by the Progressive Conservatives Party, who won a convincing majority in the 1984 Federal Elections on the back of a strong anti-corruption line. ${ }^{268}$

The LRA separated lobbyists into two tiers. ${ }^{269}$ Tier I lobbyists were those who: ${ }^{270}$

... for payment and on behalf of a client, undertake to arrange a meeting with a public office holder or to communicate with a public office holder in an attempt to influence the development, making or amendment of any federal law, regulation, policy or program or the award of any federal monetary grant or the award of any federal contract.

In short, Tier I lobbyists were those who were paid to conduct lobbying activities on behalf of a client. By contrast, a Tier II lobbyist was "an individual who, on behalf of an employer, communicates as a significant part of his or her duties with a public office holder in an attempt to influence the same type of activities as apply to a Tier I lobbyist". ${ }^{271}$ The principal difference between the two is that Tier I lobbyists were paid to represent third parties, whereas Tier II lobbyists performed lobbying as a significant part of their duties to a single employer.

Lobbying regulations in Canada have changed significantly since the implementation of the LRA, receiving significant amendments in $1997,{ }^{272} 2003,{ }^{273} 2004,{ }^{274} 2005,{ }^{275}$

\footnotetext{
${ }^{266}$ Michael Rush "The Canadian Experience: The Lobbyists Registration Act" (1998) 51 Parl Aff 516.

${ }^{267}$ Lobbyists Registration Act SC 1988 c 53.

${ }^{268}$ Michael Rush "The Canadian Experience: The Lobbyists Registration Act” (1998) 51 Parl Aff 516.

${ }^{269}$ Consumer and Corporate Affairs Canada Lobbyists Registration Act Annual Report (31 March 1990) at 5.

${ }^{270}$ Consumer and Corporate Affairs Canada Lobbyists Registration Act Annual Report (31 March 1990) at 6.

${ }^{271}$ Consumer and Corporate Affairs Canada Lobbyists Registration Act Annual Report (31 March 1990) at 6

${ }^{272}$ (Ca) Lobbyists' Code of Conduct came into force 1 March 1997.

${ }^{273}$ An Act to Amend the Lobbyists Registration Act SC 2003 c 10.

${ }^{274}$ An Act to Amend the Parliament of Canada (Ethics Commissioner and Senate Ethics Officer) SC 2004 c 7.

${ }^{275}$ Regulations Amending the Lobbyists Registration Act came into force on 20 June 2005.
} 
$2006,{ }^{276}$ and $2010 .{ }^{277}$ Present-day lobbying legislation in Canada - now known simply as the Lobbying Act to "reflect its broader scope"278 - has kept much of the original framework that it uses to identify and classify lobbyists.

(b) Lobbying Act RSC 1985 c44

The current Lobbying Act 1985 targets two categories of lobbyist: consultant lobbyists, and in-house lobbyists. Consultant lobbyists are those who are act on behalf of another person or organisation, who undertake to: ${ }^{279}$

(a) communicate with a public office holder in respect of

(i) the development of any legislative proposal by the Government of Canada or by a member of the Senate or the House of Commons,

(ii) the introduction of any Bill or resolution in either House of Parliament or the passage, defeat or amendment of any Bill or resolution that is before either House of Parliament,

(iii) the making or amendment of any regulation as defined in subsection 2(1) of the Statutory Instruments Act,

(iv) the development or amendment of any policy or program of the Government of Canada,

(v) the awarding of any grant, contribution or other financial benefit by or on behalf of Her Majesty in right of Canada, or

(vi) the awarding of any contract by or on behalf of Her Majesty in right of Canada; or

(b) arrange a meeting between a public office holder and any other person.

Consultant lobbyists are targeted on an individual basis. By contrast, the Lobbying Act 1985 requires the employer of in-house lobbyists to register, instead of the lobbyists who are in their employ. In-house registration requirements arise where: ${ }^{280}$

(a) the corporation or organization employs one or more individuals any part of whose duties is to communicate with public office holders on behalf of the employer or, if the employer is a corporation, on behalf of any subsidiary of the employer or any corporation of which the employer is a subsidiary, in respect of

(i) the development of any legislative proposal by the Government of Canada or by a member of the Senate or the House of Commons,

(ii) the introduction of any Bill or resolution in either House of Parliament or the passage, defeat or amendment of any Bill or resolution that is before either House of Parliament,

(iii) the making or amendment of any regulation as defined in subsection 2(1) of the Statutory Instruments Act,

\footnotetext{
${ }^{276}$ Federal Accountability Act SC 2006 c9.

${ }^{277}$ Designated Public Office Holder Regulations amended 20 September 2010.

278 "The Lobbying Act" (15 February 2012) Office of the Commissioner of Lobbying of Canada < http://www.ocl-cal.gc.ca/eic/site/012.nsf/eng/h_00008.html>.

${ }^{279}$ Lobbying Act RSC 1985 c44, s 5(1).

${ }^{280}$ Lobbying Act RSC 1985 c44, s 7(1).
} 
(iv) the development or amendment of any policy or program of the Government of Canada, or

(v) the awarding of any grant, contribution or other financial benefit by or on behalf of Her Majesty in right of Canada; and

(b) those duties constitute a significant part of the duties of one employee or would constitute a significant part of the duties of one employee if they were performed by only one employee.

Of course, "significant part" is an ambiguous phrase which required qualification. The Act obliges the Office of the Commissioner for Lobbying to develop and implement educational programs to ensure that the provisions of the Act are properly interpreted. ${ }^{281}$ The Office may issue "advisory opinions and interpretation bulletins with respect to the enforcement, interpretation or application" 282 of the provisions of the Act. One such interpretation bulletin has been issued for the words "significant part". It states that this threshold is met at " $20 \%$ or more of overall duties." 283 The person responsible for filing registration returns on behalf of an organisation or corporation must determine whether, across the entire entity, the amount of lobbying conducted would amount to $20 \%$ of the duties of a single employee if they were treated cumulatively. Under the Lobbying Act 1985, lobbying includes time spent communicating with public office holders, researching, drafting, planning and compiling information for these instances of communication and travel time. ${ }^{284}$

The Canadian Act also allows a number of exceptions to what might otherwise be considered "lobbying activity", including: requests for information, time spent in respect to briefings to parliamentary committees, submissions made to public office holders with respect to the application, interpretation or enforcement of existing federal legislation ${ }^{285}$ and ordinary interaction with government inspectors and regulatory authorities. ${ }^{286}$

\section{$2 \quad$ Federal lobbyists in the United States.}

The United States introduced legislation to regulate lobbyists shortly after World War II. ${ }^{287}$ Since then, Congress has consistently increased the obligations of lobbyists to register and to disclose activities, and has broadened lobbying definitions to include a wide selection of lobbyists. The complexity of current lobbying requirements in the United States - enshrined in the Lobbying Disclosure Act (LDA) ${ }^{288}$ - reflects the significant concern that has been directed towards the practice for over fifty years.

The general rule for registration prescribes that: ${ }^{289}$

\footnotetext{
${ }^{281}$ Lobbying Act RSC 1985 c44, s 4.1.

${ }^{282}$ Lobbying Act RSC 1985 c44, s 10 (1).

${ }^{283}$ Karen Shepherd, "A Significant Part of Duties ('The 20 Percent Rule')" (July 2009) Office of the Commissioner of Lobbying of Canada 〈http://ocl-cal.gc.ca/eic/site/012.nsf/eng/00115.html〉.

${ }^{284}$ Karen Shepherd, "A Significant Part of Duties ('The 20 Percent Rule')" (July 2009) Office of the Commissioner of Lobbying of Canada <http://ocl-cal.gc.ca/eic/site/012.nsf/eng/00115.html〉.

${ }^{285}$ Lobbying Act RSC 1985 c44, s 4(2)(a)-(c).

${ }^{286}$ Karen Shepherd, "A Significant Part of Duties ('The 20 Percent Rule')" (July 2009) Office of the Commissioner of Lobbying of Canada <http://ocl-cal.gc.ca/eic/site/012.nsf/eng/00115.html>.

${ }^{287}$ Foreign Agents Registration Act 22 USC $\$ 611$ (repealed).

${ }^{288}$ Lobbying Disclosure Act 2 USC $§ 1605$.

${ }^{289}$ Lobbying Disclosure Act 2 USC $§ 1603$, s (4)(A)(1).
} 
No later than 45 days after a lobbyist first makes a lobbying contact or is employed or retained to make a lobbying contact, whichever is earlier, or on the first business day after such 45th day if the 45th day is not a business day, such lobbyist (or, as provided under paragraph (2), the organization employing such lobbyist), shall register with the Secretary of the Senate and the Clerk of the House of Representatives.

The LDA defines "lobbying contact" as "any oral or written communication to a [covered official] that is made on behalf of a client" ${ }^{, 90}$ with regard to the formulation, modification or adoption of legislation or policy, the administration or execution of policy or the nomination or confirmation of persons to the Senate. ${ }^{291}$

The way in which the LDA distinguishes between non-lobbyists and lobbyists differs from the approach taken in its Canadian counterpart. All individuals must consider filing a registration upon the assumption of a paid lobbying role for someone other than him or herself. Accordingly, if an organisation with an in-house lobbyist needs to register, it must only do so once (as the lobbyist is only representing one client - the employer), whereas a consultant lobbyist's activities may necessitate several registrations each quarter based on the amount of clients he or she has represented in that time. ${ }^{292}$ Potential lobbyists must consider three elements to determine whether they are obliged to register: number of lobbying contacts, time spent lobbying and expenditure or income received.

The first threshold is met if the lobbyist makes more than one lobbying contact on behalf of his or her client. These instances of lobbying contact need not occur within the same quarterly period, but merely for the same client. The definition of "lobbying contact" in the Lobbying Disclosure Act 1995 has a number of explicit exceptions, including communications made by a public official operating in an official capacity, a church that is exempt from filing a Federal income tax return, those seeking information or to arrange an appointment, or parties required to communicate with public officials for a range of institutional reasons. ${ }^{293}$

If the lobbying contact threshold is met, then it must be determined whether the lobbyist concerned used at least 20 per cent of his or her time working for the client conducting lobbying activity. In addition to lobbying contacts, lobbying activity includes "efforts in support of such contacts, including preparation and planning activities, research and other background work". ${ }^{294}$ The percentage spent on lobbying is calculated with reference to the total time spent working for the client; for a fulltime, in-house lobbyist who works a 40-hour week, this would work out to be an average of 8 hours a week. For a consultant lobbyist who billed a client for 200 hours, this threshold would be met if 40 hours of this work was spent on lobbying activity.

If these two conditions are met, then insofar as the Lobbying Disclosure Act 1995 is concerned, the relevant party is a lobbyist. However, this lobbyist (or the organisation employing him or her) will only be required to register for the quarter if certain monetary boundaries are surpassed. For in-house lobbyists, registration is required if the organisation or corporation by which the lobbyist is employed expends in excess

\footnotetext{
${ }^{290}$ Lobbying Disclosure Act 2 USC $\S 1602$, s (8)(A).

${ }^{291}$ Lobbying Disclosure Act 2 USC $\$ 1602$, s(8)(A).

292 "Lobbying Disclosure Act Guidance" (15 February 2013) Office of the Clerk - United States House of Representatives <www.senate.gov/LDA>.

${ }^{293}$ Lobbying Disclosure Act 2 USC $§ 1602$, s (8)(B)(xviii)(I).

${ }^{294}$ Lobbying Disclosure Act 2 USC $§ 1602$, s (7).
} 
of $\$ 12,500$ on lobbying in that quarter. ${ }^{295}$ For consultant lobbyists, registration is necessary if income from the relevant client has or is expected to exceed $\$ 3,000$.

\section{$3 \quad$ Federal lobbyists in Australia}

The Register of Lobbyists is the most recent attempt to regulate lobbying activity in Australia. In 1983 the Lobbying Registration scheme was established via executive order, but was abolished in 1996 for a range of reasons. These included the fact that the register was not made publically available, and only covered consultant lobbyists. $^{296}$

The current scheme was implemented on 1 May 2008 as part of the Lobbying Code of Conduct. Unlike its predecessor, it creates a publically-accessible register, but still only targets consultant lobbyists. As one author puts it, "[i]t is hard to see how a scheme that does not cover in-house lobbyists in the nation's top companies and the advocacy staff of organised pressure groups can be said to regulate lobbying.,"297

A government representative is prohibited from knowingly engaging with lobbyists for the purposes of lobbying activity, unless the lobbyist concerned is on the Register of Lobbyists. The Code defines "lobbyist" as "any person, company or organisation who conducts lobbying activities on behalf of a third party client or whose employees conduct lobbying activities on behalf of a third party client", ${ }^{298}$ with exceptions including some not-for-profit organisations, personal representations and trade delegations.

\section{Defining "lobbying" - What can we learn from other jurisdictions?}

A number of the elements contained in lobbyists' registers from other jurisdictions may find useful implementation for the purposes of defining lobbying activity in New Zealand. These must be appraised with reference to the criteria expounded in the preceding chapter. The definition determined must effectively target potentially harmful lobbying activity whilst leaving legitimate lobbying practices unmolested. ${ }^{299}$

All law should be easily discernible. For lobbying regulations - which can impose criminal sanctions and, as somewhat of a corollary, impact civic engagement - this is doubly true. All parties considering entering into communication with government representatives must know (or be capable of discovering) whether they are subject to registration and disclosure onuses.

\section{$1 \quad$ Different categories}

The Canadian model has three classes of lobbyist (consultant, organisations with inhouse lobbyists and corporations with in-house lobbyists). Despite drawing heavily

\footnotetext{
295 "Lobbying Disclosure Act Guidance" (15 February 2013) Office of the Clerk - United States House of Representatives <www.senate.gov/LDA>.

${ }^{296}$ John Hogan, Raj Chari and Gary Murphy "Regulating Australia's Lobbyists: Coming Full Circle to Promote Democracy?" (2011) 11 J Pub Aff 35 at 37.

${ }^{297}$ Darren Halpin "Pressure Groups and Lobbying" in Rodney Smith, Ariadne Vromen and Ian Cook (eds) Contemporary Politics in Australia: Theories, Practices and Issues (Cambridge University Press, 2012) 177 at 186.

298 (Au) Lobbying Code of Conduct, cl 3.5.

${ }^{299}$ Due regard must also be given to human rights concerns. These are discussed in full in Chapter 10 of this thesis.
} 
from the Act, the Lobbying Disclosure Bill made no distinction between these categories. Neither the Member responsible for the Bill nor its original sponsor made a public statement to explain this rationale.

There are a number of advantages and disadvantages to drafting different lobbyist designations in lobbyist registers. The disadvantage is that it necessitates further legislative interpretation to ensure compliance; in other words, the law becomes less clear and thus compliance costs increase. The Canadian Lobbying Act 1985 uses a 20 per cent threshold as a means of determining which lobbyists fall within the in-house classification. Despite the fact that this has been the subject of a useful interpretation bulletin, ${ }^{300}$ concerns remain about the clarity of this aspect of the law. As one critic put it, "a company with 19 employees spending one per cent of their time on lobbying, would not have to register. However, if one of those same 19 employees were to spend 2 per cent of their time on lobbying, the company would fall within the 20 per cent threshold". ${ }^{301}$ Calculating how much cumulative time staff spend on lobbying activity is a difficult task, and it is likely that an authority investigating compliance with this rule would find similar difficulties.

Dividing lobbyists into different categories can also produce a series of benefits. For one, it allows for a more equitable distribution of bureaucratic burdens. It is arguable that consultant lobbyists have a greater tendency to produce harm than their in-house counterparts, largely due to the fact that they can represent multiple, hidden clients simultaneously (whereas an in-house lobbyist is clearly an advocate for his or her employer). Additionally, an in-house lobbyist might only spend 21 per cent of his or her time on lobbying activities, whereas a consultant lobbyist is dedicated to the task. Where regulations make the distinction, they can also impose different duties on each category. It seems manifestly unfair to impose onerous disclosure responsibilities on in-house lobbyists where less intensive measures are available, so this idea has some merit.

By contrast, the Australian Commonwealth Government's register does not apply to in-house lobbyists at all. Recent findings published in the Journal of Public Affairs appear to indicate that this approach fails to alleviate the dual harms that lobbying can present. The analysis used the Hired Guns methodology (originally devised by the Centre for Public Integrity), which evaluates the effectiveness of lobbying regulations against 48 questions and gives a mark out of 100 points. ${ }^{302}$ The Australian register scored 33 points, which is one of the lowest scores attained by any lobbying regime (beating only the European Parliament and Germany, who each employed registers which were merely voluntary at the time) ${ }^{303}$ This view has been echoed by former New South Wales liberal leader and prominent lobbyist Peter Collins, who claimed that a failure to capture in-house lobbyists meant that much of the related activity "is unregulated and invisible and constitutes the vast majority of ministerial diaries and

\footnotetext{
${ }^{300}$ Karen E Shepherd “A Significant Part of Duties ('The 20\% Rule')” (July 2009) Office of the Commissioner of Lobbying of Canada <https://ocl-cal.gc.ca/eic/site/012.nsf/eng/00115.html>.

${ }^{301}$ W Scott Thurlow "New Obligations of MPs under the Lobbying Act" (2010) 33 Canadian Parl Rev 46 at 47.

${ }^{302}$ Robert Morlino, Leah Rush and Derek Willis "Hired Guns - Initial Report" (15 May 2003) The Centre for Public Integrity <www.publicintegrity.org>.

${ }^{303}$ John Hogan, Raj Chari and Gary Murphy "Regulating Australia's Lobbyists: Coming Full Circle to Promote Democracy?" (2011) 11 J Pub Aff 35 at 40.
} 
appointments and is where 95 per cent of lobbying happens." ${ }^{304}$ This is a valid point. Many instances of harmful lobbying - such as the two instances discussed in Chapter II - are carried out by in-house lobbyists.

An effective lobbyists' register necessitates the inclusion of both in-house and consultant lobbyists. While a distinction between the two can help avoid unfair burdens on in-house lobbyists, the simplest solution would be to impose one rule for all types of lobbyists.

"For payment"

The inclusion of payment as an essential element of lobbying activity requiring registration is advisable. Forcing some unpaid lobbyists to register could detrimentally affect civic engagement by imposing procedural burdens on ordinary conversations between public officials and private constituents. For example, the distinction between paid and unpaid lobbyists makes explicit the intention to avoid capturing lobbyists such as individuals consulting with their MPs on personal matters.

It must be conceded that the inclusion of the requirement for payment will allow some lobbyists to slip through the cracks; lobbyists may circumvent it by working on a pro bono basis for clients, and unscrupulous lobbyists might contrive to invent other methods for their clients to compensate them which fall outside of the legislative appreciation of "payment". The latter may be circumscribed by drafting a legislative interpretation of payment as including money as well as any other valuable consideration, including contracts and agreements to make such a payment. ${ }^{305}$

\section{$3 \quad$ Lobbying contacts}

The United States' Lobbying Disclosure Act 1995 is unique in the sense that it only requires registration if the lobbyist carries out - or intends to carry out - more than one instance of lobbying activity. This provision can be used to eliminate a number of concerns held by detractors of lobbying registers.

A common criticism of lobbying regulations is that they might capture chance run-ins between public officials and lobbyists, or one-off representations made by e-mail or in person. ${ }^{306}$ A well-crafted lobbying contact provision should include two elements. The first qualifies what type of premeditation should be necessary for communications to count as lobbying activity, and the second explains how regularly this must occur before registration duties are incurred.

The Lobbying Disclosure Bill stated that communication would include that which is "not limited to communications in a formal of prearranged setting". ${ }^{307}$ This wording is inadvisable. Lobbying activity should not include chance run-ins with public officials. This could cause constituents to be wary of approaching government officials in public

\footnotetext{
${ }^{304}$ Nic Christensen "Lobbying regulations cover "the tip not the iceberg"' (18 March 2013) Mumbrella $<$ http://mumbrella.com.au/lobbying-regulation-covers-just-the-tip-not-the-iceberg-145998>.

${ }^{305}$ Compare Lobbying Act RSC 1985 c55, s 2.

${ }^{306}$ W Scott Thurlow "New Obligations of MPs under the Lobbying Act" (2010) 33 Canadian Parl Rev 46 at 47.

${ }^{307}$ Lobbying Disclosure Bill 2012 (15-1), cl 4.
} 
situations (including conferences and chance run-ins at supermarkets, for example). ${ }^{308}$ Lobbying contact should be defined to include only pre-arranged meetings, targeted emails (and other personal digital communications), phone calls and letters. A provision which makes this point explicitly would go some way to reducing a potential downturn in civic engagement. An exception to the general rule that lobbying activity only counts when it is pre-arranged might include instances where lobbyists arrive unannounced at the offices or homes of government representatives, which is reasonable given that in these instances it was the planned intention of the lobbyist to conduct lobbying activity.

Registers should include both in-house and consultant lobbyists, who are paid to lobby. Registration duties should only be imposed where these lobbyists conduct lobbying activity which has a certain degree of premeditation or deliberateness. The Attorney-General indicated that the Bill should not capture "people who send a oneoff email to their Member of Parliament on behalf of their incorporated farm or small business regarding any government policy." ${ }^{309}$ His statement is correct; it is likely that a requirement to fill out paperwork under threat of criminal sanctions would deter these types of communications, which are an essential element of civic engagement.

This scenario necessitates a further provision with respect to lobbying contacts; namely, that registration requirements should only be incurred where lobbyists make a second lobbying contact within a certain period of time, ${ }^{310}$ or where a contract or retainer is agreed upon whereby the lobbyist will make multiple contacts. This allows the register to capture intensive lobbying efforts without detrimentally affecting the participatory efforts of ordinary constituents.

\section{$4 \quad$ Exemptions}

Each of the studied lobbyists' registers permit that certain types of lobbying activity should not incur registration requirements. This is to allow government bodies to carry out their ordinary duties when carrying out intra-governmental communications, to prevent transparency where it is not suitable (including, for example, sensitive commercial negotiations) and also to facilitate input from third parties where mechanisms already exist to ensure a proper degree of transparency.

The Supplementary Order Paper put forward by Charles Chuavel MP suggested an amendment to the Lobbying Disclosure Bill which would have broadened the list of parties that would not be identified as lobbyists to include (when acting in an official capacity):

(b) any person employed by, or serving in, or working under a contract for services for, or working on secondment to-

\footnotetext{
${ }^{308}$ Anthony Hubbard "The Secret Service" (15/4/2012) Stuff

<http://www.stuff.co.nz/national/politics/6744860/The-secret-service>; W Scott Thurlow "New Obligations of MPs under the Lobbying Act" (2010) 33 Canadian Parl Rev 46 at 47.

${ }^{309}$ Report of the Attorney-General under the New Zealand Bill of Rights Act 1990 on the Lobbying Disclosure Bill (House of Representatives, 2012) at 5.

${ }^{310}$ Within a given period of time. For example, under the Lobbying Disclosure Act 1995, two lobbying contacts must be made within the same quarter in order to trigger registration requirements. "Lobbying Disclosure Act Guidance" (15 February 2013) Office of the Clerk - United States House of Representatives <www.senate.gov/LDA〉.
} 
(i) any department of the public service listed in Schedule 1 of the State Sector Act 1988:

(ii) any Crown entity listed in Schedule 1 or Schedule 2 of the Crown Entities Act 2004:

(iii) the New Zealand Defence Force:

(iv) the New Zealand Police:

(v) the New Zealand Security Intelligence Service:

(vi) the Parliamentary Counsel Office; or

(vii) the Office of the Clerk of the House of Representatives:

(viii) the Parliamentary Service:

(ix) the Reserve Bank of New Zealand:

(x) any Office of Parliament;

In addition to this, the Bill provided exceptions for "any oral or written submission made to the House or any of its committees in proceedings that are a matter of public record" and "any communication which is restricted to a request for information". This is commendable; however, the following Chapter recommends that the scope of potential legislation be increased to include public office holders that are not Members of Parliament. In keeping with this recommendation, the above exception for communications made that are already a matter of public record should be expanded to those instances which are similarly transparent that involve public office holders who are not part of the House of Representatives.

\section{Conclusions}

Lobbying is difficult to define for legislative purposes. There is no perfect way to define lobbying activity or lobbyists. Definitional provisions must first ensure that they do not hamper legitimate lobbying activity before ensuring that harmful lobbying is captured by the register.

Payment is an essential element of the definitional formulation, because it makes discernible the relationship between the lobbyist and the client directing his or her actions. Additionally, a provision which requires the performance or intention to perform multiple lobbying contacts would remove the possibility of chance run-ins or one-off contacts from falling under the ambit of the register, thus leaving constituents free to conduct minor lobbying activity before incurring registration responsibilities.

Having one rule for all lobbyists - as opposed to creating different types of lobbying categories with different obligations - would ensure clarity. If this can be achieved without imposing undue bureaucratic burdens whilst also guaranteeing a moderate degree of transparency, then fears raised about a reduction in civic engagement by lobbyists may be somewhat mitigated. Chapter VII discusses the reporting requirements of lobbyists, and makes recommendations for how these could be kept to a minimum for all lobbyists whilst also ensuring transparency. 


\section{Public Office Holders - Who is Lobbied?}

\section{A Introduction}

The second core element of lobbying disclosure legislation is the determination of individuals who might rightly be considered "lobbied" for the purpose of the law. Some approaches have been broadly encompassing, including Members of Parliament and a full range of public officials and offices, whilst others have specifically targeted Ministers and other "key" decision-making individuals. As with other elements of disclosure legislation, the balance must be struck between provisions which cover enough types of activities to meet the objectives of the law and the need for ethical lobbying activity to be fostered and legitimised, through clarity and manageable bureaucratic burdens. This chapter assesses the usefulness of the approaches adopted in the Lobbying Disclosure Bill and in other jurisdictions. It recommends that an exhaustive list of public office holders would be an appropriate strategy for the New Zealand context.

\section{B The Lobbying Disclosure Bill}

As noted earlier in this paper, the Lobbying Disclosure Bill covered only those communications which were made with Members of Parliament and their staff. ${ }^{311}$ This approach is problematic. Members of Parliament are generally expected to "toe the party line", ${ }^{312}$ which restricts the extent to which they are able to freely influence Parliamentary proceedings. ${ }^{313}$ By contrast, public sector officials are expected to provide "free and frank" 314 advice to Ministers, "without bias towards one political party or another." 315 It follows that public officials may take a broader range of factors (such as arguments put forward by lobbyists) into account when drafting influential advice to executive government.

For this reason, lobbyists often target officials. This strategy has been confirmed by Chief Executive Officer of Business New Zealand and prominent lobbyist Phil O'Reilly. ${ }^{316}$ Law firm Chen Palmer raised this point while the Bill was in committee, claiming that "the omission of communication with such officials by lobbyists would represent a significant 'loophole' for lobbyists, and may encourage behaviour which the Bill aims to prevent." 317 The MP in charge of the Lobbying Disclosure Bill -Ms Holly Walker - admitted that "there's a very legitimate case to be made" for including lobbyists' meetings with officials, but the bill was "a place to start". 318

\footnotetext{
${ }^{311}$ Lobbying Disclosure Bill 2012 (15-1), cl4.

312 Christopher J Kam Party Discipline and Parliamentary Politics (Cambridge University Press, 2009) at 16.

${ }^{313}$ David Lindsey "A Brief History of Conscience Voting in New Zealand" (paper presented at the Australasian Study of Parliament Conference, Adelaide, 23 August 2007) at 2.

${ }^{314}$ Cabinet Office Cabinet Manual 2008 at [3.52].

${ }^{315}$ Cabinet Office Cabinet Manual 2008 at [3.51].

${ }^{316}$ Anthony Hubbard "The Secret Service" (15/4/2012) Stuff

<http://www.stuff.co.nz/national/politics/6744860/The-secret-service>.

${ }^{317}$ Chen Palmer New Zealand Public and Employment Law Specialists "Submission to the Government Administration Committee on the Lobbying Disclosure Bill" (17 October 2012) at [25].

${ }^{318}$ Anthony Hubbard "The Secret Service" (15/4/2012) Stuff

$<$ http://www.stuff.co.nz/national/politics/6744860/The-secret-service>.
} 
Canada's first attempt to enforce a modicum of transparency around lobbying cast a very wide net. The Lobbyists Registration Act $1988^{319}$ mandated registration for any lobbying activity where the target was "any officer or employee of Her Majesty in right of Canada and includes virtually everyone occupying a position in the federal government." ${ }^{, 320}$ The modern Lobbying Act 1985 identifies members of the Senate and House of Commons (and respective staff), persons appointed to a position with approval of the Governor in Council of a Minister (other than Judges), and officers, directors and employees of federal boards, commissions or tribunals, members of the Canadian Armed Forces and members of the Royal Canadian Mounted Police. ${ }^{321}$

\section{$2 \quad$ United States}

The Lobbying Disclosure Act 1995 takes a more prescriptive role in determining with whom lobbying is a registerable activity. It divides public office holders into two broad categories: covered executive branch officials ${ }^{322}$ and covered legislative branch officials. $^{323}$

Covered executive branch officials include: the President, Vice President, officers or employees of these positions or in levels I-V of the Executive Schedule, members of the uniformed services of certain pay grades and officers or employees who serve "in a position of a confidential, policy-determining, policy-making or policy-advocating character". 324

Covered legislative branch officials include Members of Congress and elected officers of either House, associated staff, and any other legislative branch employee serving in a position described under the Ethics in Government Act 1978. ${ }^{325}$ The Ethics in Government Act 1978 prescribes "officer or employee of the Congress" as meaning all those employed in the legislative branch who are paid at least 120 per cent of the minimum rate payable for such positions. ${ }^{326}$

\section{$3 \quad$ Australia}

The Lobbying Code of Conduct describes "government representatives" as including:

a Minister, a Parliamentary Secretary, a person employed or engaged by a Minister or a Parliamentary Secretary under the Members of Parliament (Staff) Act 1984, an Agency Head or a person employed under the Public Service Act 1999, a person engaged as a contractor or consultant by an Australian Government agency whose staff are employed under the Public Service Act 1999 or a member of the Australian Defence Force.

\footnotetext{
${ }^{319}$ Lobbyists Registration Act RSC 1998 c 53.

${ }^{320}$ Consumer and Corporate Affairs Canada Lobbyists Registration Act Annual Report (31 March $1990)$ at 5.

${ }^{321}$ Lobbying Act RSC 1985 c44, s 2.

${ }^{322}$ Lobbying Disclosure Act 19952 USC $§ 1602$ (3).

${ }^{323}$ Lobbying Disclosure Act 19952 USC $\$ 1602$ (4).

${ }^{324}$ Lobbying Disclosure Act 19952 USC $\$ 1602$ (3)(F).

${ }^{325}$ Lobbying Disclosure Act 19952 USC $\$ 1602$ (4)(D).

${ }^{326}$ Ethics in Government 19785 USC $§ 109$ (13)(B).
} 
The Code "does not encompass any other Members of the Legislative Assembly." "327

\section{Public office holders - What can we learn from other jurisdictions?}

The Lobbying Disclosure Bill was unambitious in its attempt to regulate only those lobbying activities which were carried out with respect to Members of Parliament and their staff. This deficiency is highlighted by the existing regulations in Canada, the United States and Australia. All of the studied instruments included a much more broad definition of public office holder or government representative for the purposes of registerable activity. These instruments varied significantly, however, which points to the need for the relevant provisions to be tailored to the specific jurisdiction in which they are to be employed.

The boundary between public officials with whom lobbying is a registerable activity and those with who it is not can become blurred. This is particularly true in cases where the law has expanded beyond senior or executive staff. In the United States, this blurring has been mitigated by the utilisation of pay-brackets as a means of identifying relevant public officials. This is understandable, given that there were over 2.65 million executive branch employees in the United States after Barack Obama's first year in the White House. ${ }^{328}$

Due to New Zealand's drastically smaller state sector, it is feasible that an exhaustive list could be drafted which specified which positions would fall under potential lobbying legislation. While outside the scope of this paper, it is imaginable that this list would be compiled via consultation with relevant public service actors and subject to change as positions are abolished or created. Where possible, an exhaustive list is preferable to one which is not. This is because an exhaustive list lends a greater deal of clarity for lobbyists, clients and public officials. The inclusion of Members of Parliament and their staff is certainly a good place for potential legislation to start. The provisions should not stop there. As a preliminary matter, the law should also cover senior and executive staff of Ministries and other departments of the public service as listed under Schedule 1 of the State Sector Act 1988. These officials have significant clout in decision-making processes and are thus likely to be subject to intensive lobbying.

\footnotetext{
${ }^{327}$ John Hogan, Gary Murphy and Raj Chari "Regulating the Influence Game in Australia" (2011) 57 Aust J Polit and Hist 102 at 106.

328 "Data, Analysis and Documentation: Federal Employment Reports" (2011) United States Office of Personnel Management <https://www.opm.gov/policy-data-oversight/data-analysisdocumentation/federal-employment-reports/historical-tables/executive-branch-civilian-employmentsince-1940/>.
} 


\section{Registration and Disclosure Requirements}

\section{A Introduction}

While it is clear that the target of lobbying legislation must be identified with precision, it is also essential that the disclosure requirements are tailored to meet the objectives of the legislation. A successful lobbyists' register would be probing and effective, but it would also only impose such burdens which are necessary to achieve its objectives. It would not have a strong deterrent effect on lobbying activity, and it would also serve to legitimise lobbying insofar as public opinion is concerned.

The Lobbying Disclosure Bill prohibited non-registered parties from conducting lobbying (activity as defined in the preceding chapter). To register, a lobbyist would have been required to submit his or her name, business address, the name and business address of any employer related to the lobbying activity and a description of the role that he or she performs for this employer. ${ }^{329}$ The Bill would also have required lobbyists to file a lobbying return upon registration, and one every three months thereafter. ${ }^{330}$ Lobbying returns would have included information to paint a clearer picture of lobbying activity undertaken by the registered party. The Bill required these to include information to identify the lobbyist's client, the targeted public office holder, any controlling interests of the client, the communication technique employed, and the subject matter lobbying activity undertaken. ${ }^{331}$

Effective registers tell the public a number of useful pieces of information. As a basic element, they state the identity of the lobbyist, and that of the client(s) paying him or her. The lobbyist's identity must be known in order for there to be transparency with respect to the relationship between the public official and the lobbyist. The client's identity must be disclosed so that potential conflicts of interest and - more generally the overall perspective from which the lobbying activity stems can be determined. ${ }^{332}$ To be effective, registers must also give information with respect to the subject on which public officials are lobbied. Without this information, the public is unable to do more than infer the purpose of the lobbying activity with reference to the identity of the client concerned. Other information should be required where it could increase the amount of relevant information available for the public to understand the nature of lobbying activities. These requirements, when fulfilled, constitute what the OECD referred to as "meaningful disclosure". 333

In achieving efficacy, registers must avoid becoming a barrier to lobbying activity. As discussed in the preceding section, vague directions and burdensome onuses can dissuade lobbyists from engaging with government representatives. The costs and expertise required to comply with the stipulations of a register must also be kept to a minimum, otherwise these factors may deter potential lobbying activity. Finally, registers should avoid becoming invasive by unnecessarily requiring information, as this would discourage lobbying activity by lobbyists who seek some degree of

\footnotetext{
${ }^{329}$ Lobbying Disclosure Bill 2012 (15-1), cl 6.

${ }^{330}$ Lobbying Disclosure Bill 2012 (15-1), cl 7(8).

${ }^{331}$ Lobbying Disclosure Bill 2012 (15-1), cl 7(7).

332 OECD Lobbyists, Governments and Public Trust, Volume 1: Increasing Transparency through Legislation (OECD Publishing, 2009) at 59.

${ }^{333}$ OECD Lobbyists, Governments and Public Trust, Volume 1: Increasing Transparency through Legislation (OECD Publishing, 2009) at 58.
} 
discretion. In short, a lobbyists' register must shine a light on lobbying activity without altering the nature or frequency of ordinary lobbying.

Those states that maintain a register of lobbyists usually require a lobbyist to sign up within a short period of time after a "trigger" event. The process by which the lobbyist registers differs between jurisdictions, but the process typically involves an initial return which is sent by the lobbyist to the responsible department (establishing the lobbyist in the register), followed by a series of returns over a given period of time which serve to update the information held about the lobbyist's activity. The following analyses are based on this structure. For each jurisdiction, the process (or "trigger events") of registration are described, followed by an analysis of disclosure requirements. This is then followed by recommendations for a register of lobbyists in New Zealand. It concludes that the disclosure requirements in the Lobbying Disclosure Bill contained a number of flaws which could have prevented it from fully realising its objective. Modifications are suggested to rectify this issue. Additionally, this chapter makes recommendations to lessen the bureaucratic burden imposed by the registration requirements in the Lobbying Disclosure Bill, without compromising on the degree of transparency it could deliver.

\section{B Registration and disclosure requirements - International approaches at a glance \\ $1 \quad$ Canada}

(a) Registration

Under the Lobbying Act 1985, consultant lobbyists and in-house lobbyists are subject to registration and disclosure requirements of differing intensity.

Consultant lobbyists must file a return if he or she "for payment, on behalf of any person or organisation, undertakes to... communicate with a public office holder" ${ }^{334}$ in respect of a range of subjects. Registration requirements are incurred for consultants on the outset of an "undertaking" to carry out lobbying activity. It is defined as "an agreement or contract, written or verbal, between a client and a consultant lobbyist, within the context of which the lobbyist will seek to communicate with public office holders on behalf of the client." 335 Historically, the Commissioner for Lobbying has taken an all-encompassing approach to these agreements, stating, "they may be very broad and can refer to a variety of lobbying activities or, alternatively, it may be more narrowly focussed." ${ }^{336}$ A consultant lobbyist is responsible for filing his or her own registration return with the Office of the Commissioner of Lobbying of Canada. This must be completed within 10 days of entering into an undertaking on behalf of a client. ${ }^{337}$

For in-house lobbyists, the undertaking may be initiated by the lobbyist or the government. ${ }^{338}$ Registration duties for in-house lobbyists fall to the most senior officer

\footnotetext{
${ }^{334}$ Lobbying Act RSC 1985 c55, s 5(1) (emphasis added).

335 "Registration Requirements for Consultant Lobbyists" (1 July 2012) A Guide to Registration <https://ocl-cal.gc.ca/eic/site/012.nsf/eng/00485.html\#overview> 3.

336 "Registration Requirements for Consultant Lobbyists" (1 July 2012) A Guide to Registration <https://ocl-cal.gc.ca/eic/site/012.nsf/eng/00485.html\#overview> 3.

${ }^{337}$ Lobbying Act RSC 1985 c55, s 5(1) (emphasis added).

338 John Banigan "Lobbying Law" CMA Magazine (Toronto, October 2005) at 46.
} 
in the organisation or corporation. ${ }^{339}$ In-house lobbyists have much longer to make their initial returns, "not later than two months after the day on which the requirement to file a return first arises.",340

(b) Disclosure

There are a number of different returns which a lobbyist may be required to complete under the Lobbying Act 1985. Initial returns require the most substantial amount of information, and other returns must be made on an on-going basis.

(i) Registration information for consultant lobbyists

The initial return must include the name and business address of the lobbyist and the client, and any controlling interest of the client. If the client is a corporation, a range of disclosures must be made with respect to subsidiaries. If the client receives government funding, then the agency responsible for this allocation must be identified, in addition to the amount that is received. The return must include the subject-matter in respect of which the lobbyist intends to communicate about, including relevant legislative instruments and policies. The departments or government institutions that are to be lobbied must be identified. Communication methods must also be identified. $^{341}$

(ii) Registration information for in-house lobbyists

In addition to the above requirements, officers filing on behalf of in-house lobbyists must also disclose a number of pieces of information about the lobbyist's employer. The name and business address of the employer (regardless of whether it is a corporation or organisation) must be disclosed, in addition to a summary of the employer's business activities. A list must also be compiled which includes the name of each employee who conducts lobbying activity as a significant part of their duties, in addition to a list of all senior officers who lobby in any capacity (without the requirement that this constitutes a "significant part"342).

(iii) Monthly returns

Once an initial return has been made, both in-house and consultant lobbyists must complete returns on a monthly basis. These serve to update the register on the activities on the lobbyist, and also provide further information about lobbying activities which concern key decision-makers.

The monthly returns are crucial to the maintenance of an effective register. Initial returns are usually filed in anticipation of lobbying activity to be performed in the future; if this activity does not occur, or takes a different form, then the register must be updated.

In addition to its function as a means to maintain the accuracy of the register, monthly reports provide disclosure about some types of lobbying activity. The reform which occurred in 2008 introduced a novel provision which enabled further scrutiny of

\footnotetext{
${ }^{339}$ W Scott Thurlow "New Obligations of MPs under the Lobbying Act" (2010) 33 Canadian Parliamentary Review 46.

${ }^{340}$ Lobbying Act RSC 1985 c55, s 7(2).

${ }^{341}$ Lobbying Act RSC 1985 c55, s 5(2).

${ }^{342}$ Lobbying Act RSC 1985 c55, s 7(3)(f.1).
} 
lobbying activity where the target is a key decision maker. Those decision makers termed "Designated Public Office Holders" - include: ${ }^{343}$

(a) a minister of the Crown or a minister of state and any person employed in his or her office who is appointed under subsection 128(1) of the Public Service Employment Act,

(b) any other public office holder who, in a department within the meaning of paragraph $(a),(a .1)$ or $(d)$ of the definition "department" in section 2 of the Financial Administration Act,

(i) occupies the senior executive position, whether by the title of deputy minister, chief executive officer or by some other title, or

(ii) is an associate deputy minister or an assistant deputy minister or occupies a position of comparable rank

The Governor in Council also has the power to designate other public office holders if he or she believes that this will advance the purposes and provisions of the Act. ${ }^{344}$ In monthly returns, lobbyists in Canada must identify the designated public office holder, the date on which communications took place, particulars to identify the subjectmatter of that instance of communication and any other information that is prescribed. $^{345}$

If the register remains accurate, and no contact is made with designated public office holders, then no monthly return is required. If no monthly return is made over a period of 6 months, then a return must be filed to confirm that no update is necessary. Status as a registered lobbyist is not terminated automatically; the lobbyist must inform the Commissioner of Lobbying if he or she wishes to discharge obligations incurred under the Act. ${ }^{346}$

\section{$2 \quad$ United States}

As noted in Chapter 5, the Lobbying Disclosure Act 1995 does not make a meaningful distinction between in-house and consultant lobbyists. Given this amalgamation it should not be surprising that both types of lobbyists are subject to the same registration and disclosure requirements.

(a) Registration

One of two events can trigger the requirement for lobbyists to register, once it is clear that lobbying constitutes 20 per cent of the individual's workload, and that this lobbying has/will result in an income of $\$ 2,500$ (for consultant lobbyists) ${ }^{347}$ or an expenditure of $\$ 10,000$ (for "organizations whose employees engage in lobbying activities on its own behalf"). ${ }^{348}$ The first event which can trigger an obligation to register occurs when a lobbyist makes a second lobbying contact, and the other event is where the lobbyist is employed or retained to do so. ${ }^{349}$

\footnotetext{
${ }^{343}$ Lobbying Act RSC 1985 c55, s 2(1).

${ }^{344}$ Lobbying Act RSC 1985 c55, s 12(c.1).

${ }^{345}$ Lobbying Act RSC 1985 c55, ss 5(3)(a), 7(4)(a).

${ }^{346}$ Lobbying Act RSC 1985 c55, ss 5(3)(c), 7(4)(c).

${ }^{347}$ Lobbying Disclosure Act 19952 USC $§ 1603(\mathrm{a})(3)(\mathrm{A})(\mathrm{i})$.

${ }^{348}$ Lobbying Disclosure Act 19952 USC § 1603(a)(3)(A)(ii).

${ }^{349}$ Lobbying Disclosure Act Guidance" (15 February 2013) Office of the Clerk - United States House of Representatives <www.senate.gov/LDA>.
} 
The lobbying firm or organisation (or lobbyist, where he or she is self-employed) then has 45 days to file an LD-1DS form with the Secretary of the Senate. ${ }^{350}$ This threepage document can be completed online, and is accompanied by comprehensive guidance provided by the United States House of Representatives and the Senate. ${ }^{351}$

(b) Disclosure

(i) Initial returns

In many respects, the Lobbying Disclosure Act 1995 is similar to its Canadian counterpart in terms of the information which must be disclosed by lobbyists upon initial registration. It requires registrants to disclose information to identify lobbyists and clients and a description of the business activities of the client. General issue areas must be identified if they are to be the subject of lobbying activity. ${ }^{352}$

Registration returns in the United States must also include particulars to identify persons or organisations who have contributed more than $\$ 5,000$ toward lobbying activities, and which have a large degree of control or supervisory powers over the function of the lobbyist. ${ }^{353}$ Additionally, returns must "contain the name, address, principal place of business, amount of any contribution greater than $\$ 5,000$ to the lobbying activities of the registrant, and approximate percentage of ownership in the client of any foreign entity". 354

(ii) Semi-annual reports

In addition to initial returns, registrants must complete and file reports within 45 days of the first day of January and July every year with the Secretary of the Senate and the Clerk of the House of Representatives. As is the case with the monthly returns under the Canadian Lobbying Act 1985, the Lobbying Disclosure Act 1995 includes this requirement so that registrants' details remain current and accurate.

For lobbying firms, these semi-annual reports must also include a "good faith estimate" $^{\text {"355 }}$ of the amount of income received during the semi-annual period from the client. For lobbyists who self-advocate (i.e. in-house lobbyists), the semi-annual reports must include "a good faith estimate of the total expenses that the registrant and its employees incurred in connection with lobbying activities". 356

Again, the lobbyist remains registered (and thus responsible for filing returns) until a termination notification is given to the Secretary of the Senate and the Clerk of the House of Representatives. ${ }^{357}$

\footnotetext{
${ }^{350}$ Lobbying Disclosure Act 19952 USC $§ 1603(a)(1)$.

351 "Lobbying Registration (LD-1DS) Sample Form" (December 2009) Office of the Clerk: United

States House of Representatives <lobbyingdisclosure.house.gov>.

${ }^{352}$ Lobbying Disclosure Act 19952 USC $§ 1603(b)$.

${ }^{353}$ Lobbying Disclosure Act 19952 USC $\$ 1603$ (b)(4).

${ }^{354}$ Lobbying Disclosure Act 19952 USC $§ 1603(\mathrm{~b})(4)$.

${ }^{355}$ Lobbying Disclosure Act 19952 USC $\$ 1603$ (a)(3).

${ }^{356}$ Lobbying Disclosure Act 19952 USC $§ 1603$ (a)(4).

${ }^{357}$ Lobbying Disclosure Act 19952 USC $§ 1603(d)$.
} 
The non-legislative Lobbying Code of Conduct obliges consultant lobbyists to register if they wish to communicate with government representatives. Returns are filed with the Secretary of the Department of the Prime Minister and Cabinet, and must include: ${ }^{358}$

i. the business registration details, including trading names, of the lobbyist including, where the business is not a publicly listed company, the names of owners, partners or major shareholders, as applicable;

ii. the names and positions of persons employed, contracted or otherwise engaged by the lobbyist to carry out lobbying activities;

iii. whether a person referred to in clause 5.1(a)(ii) above is a former government representative (as defined in clause 3.3), and if so, the date the person became a former government representative; and

iv. subject to clause 5.2, the names of clients on whose behalf the lobbyist conducts lobbying activities.

The Code defines "government representative" as including ministers, parliamentary secretaries, persons employed or engaged by these parties under the Members of Parliament (Staff) Act 1984, agency heads, employees under the Public Service Act 1999 and members of the Australian Defence Force. ${ }^{359}$

\section{Registration and disclosure - What can we learn from other jurisdictions?}

As mentioned at the outset of this chapter, the OECD espoused three core disclosure requirements necessary for the information contained in a lobbyists' register to be meaningful. ${ }^{360}$ This information must enable viewers to identify the interest represented (i.e. the "client"), the object of the lobbying activity, and the government institutions being lobbied. These categories are "susceptible to expansion", ${ }^{361}$ but serve as a good starting-point for effective disclosure requirements.

\section{$1 \quad$ Minimum requirements}

When compared to its Canadian and United States counterparts, the disclosure requirements of the Australian Register of Lobbyists seem rudimentary. This perception is reinforced by reference to the afore-mentioned core disclosure requirements. The Australian register does not require lobbyists to disclose the object of their lobbying activity, nor the government institutions which are to be lobbied. This means that interested members of the public are merely left to speculate as to the activities of lobbyists around the Commonwealth Government. Given the generally low esteem in which lobbyists are held, it is unlikely that such speculation will lead to conclusions which engender a positive outlook on the effect that lobbyists have on decision-making processes. It is reasonable to conclude that the provisions of the Lobbying Code of Conduct are not useful for the purposes of potential disclosure requirements in New Zealand.

\footnotetext{
358 (Au) Lobbying Code of Conduct, cl 5.1a.

359 (Au) Lobbying Code of Conduct, cl 3.3.

${ }^{360}$ OECD Lobbyists, Governments and Public Trust, Volume 1: Increasing Transparency through Legislation (OECD Publishing, 2009) at 58.

${ }^{361}$ OECD Lobbyists, Governments and Public Trust, Volume 1: Increasing Transparency through Legislation (OECD Publishing, 2009) at 58.
} 
The Lobbying Disclosure Bill contained a number of Clauses which sought to make it more difficult for controlling interests to conceal their participation in lobbying activity. This has been a common feature of lobbying legislation across regulating jurisdictions.

International legislation is yet to surmount a number of issues concerned with the proper identification of a lobbyist's "client". Returns commonly must include the name and business address of the client, and also the name and business address of, for example, "any person or organisation that, to the knowledge of the individual, controls or directs the activities of the client and has a direct interest in the outcome of the individual's activities on behalf of the client." ${ }^{362}$ This provision is open to two avenues of abuse. Firstly, the actual client of any given lobbying activity can enlist an intermediary to interact with the lobbyist, thus disguising its identity. Secondly, lobbyists can remain wilfully ignorant of the true identity of the client who has initiated the lobbying activity, seemingly avoiding the need to disclose the information that would otherwise be known to him or her. The Office for the Commissioner of Lobbying of Canada has identified a trend which seems to be the result of one - or both - of these loopholes. In 2011, it noted that: ${ }^{363}$

\begin{abstract}
Some consultant lobbyists are being 'sub-contracted' by lobbying firms to undertake lobbying activities and represent a specific client. Currently, the Act does not clearly indicate that lobbyists should disclose the actual interest they represent. Rather, it asks them to disclose the 'client' which could be interpreted as the consulting firm which has, in fact, hired the lobbyist. The Office has adopted the practice of requiring lobbyists, when listing a consulting firm as the client, to also indicate the actual client whose interests they are ultimately representing.
\end{abstract}

In cases where the initiating client is a corporation or organisation, controlling interests are discernible through the identification of subsidiary status or shareholder ownership. This avenue was covered by the Lobbying Disclosure Bill, and it is recommended that this approach be adopted in future attempts to regulate lobbyists in New Zealand.

\title{
3 Disclosure of income and expenditure
}

The United States federal disclosure obligations are at the diametrically opposite end of the scale from those imposed by the Australian Code. The Lobbying Disclosure Act 1995 imposes obligations which are the most comprehensive in the world. ${ }^{364}$ In addition to fulfilling the core requirements of the OECD, the LDA includes a number of requirements which go beyond the bare essentials of an effective lobbying regime.

Most notably, the LDA requires lobbyists to disclose the income or expenditure (for consultant or self-representing lobbyists, respectively) pertaining to their registerable activities. This requirement has provided a great deal of insight into the overall expenditures of lobbying activity in the United States; for example, between 1998 and

\footnotetext{
${ }^{362}$ Lobbying Act RSC 1985 c55, s 5(2)(b).

363 "The Registry of Lobbyists" (January 2012) Office of the Commissioner of Lobbying of Canada <http://ocl-cal.gc.ca/eic/site/012.nsf/eng/00442.html>.

${ }^{364}$ Raj Chari, John Hogan, Gary Murphy Regulating Lobbying: A Global Comparison (Manchester University Press, 2010) at 100.
} 
2012, lobbying expenditure rose from $\$ 1.45$ billion to $\$ 3.6$ billion. ${ }^{365}$ The identification of this trend is undeniably important for policymakers, who must frame further lobbying law reform with respect to the pervasiveness of the practice. The provision enables the public to discover how much money is being spent by whom, and for what purpose. Presumably, this is to shine a light on the extent to which money can influence political decision-making. The value of this approach was reinforced by the results of the Troubled Asset Relief Program mentioned in Chapter II of this paper. The disclosure of lobbying expenditure meant that researchers were able to identify a strong relationship between the amounts that parties spent on lobbying and their resultant Troubled Asset Relief Program fund allocations in 2008. One paper found that "firms that lobbied or had other types of political connections of were not only more likely to receive TARP funds, they also received a greater amount of support earlier than firms that were not politically involved through lobbying". ${ }^{366}$

It is not clear whether a requirement to disclose lobbying expenditure would be useful in New Zealand. In New Zealand, lobbying is not conducted on a financial scale comparable to that seen in the United States. Additionally, the LDA requirement was implemented following decades of lobbying law reform, which allowed drafters to take stock of lobbying practices and regulatory impacts before deciding to add it to the list of disclosed information. Without an evident and pressing need for the disclosure of lobbying expenditure in New Zealand, drafters would be ill-advised to include a similar provision in any forthcoming legislation. As noted elsewhere in this paper, unnecessary disclosure requirements may be perceived as invasive, and could result in a decline in civic engagement and pose a threat to a number of human rights.

\section{$4 \quad$ Disclosure of lobbyists who are ex-public office holders}

Money is not the only currency which can have a distorting effect on political decision-making. Relationships are a key element of lobbying activity, given that the "experienced lobbyist learns that effectiveness and reputation depend in large part on an ability to cultivate and nurture long term relationships [with policy makers]." 367 There is a perception that "experience in government allows former officials to develop a network of friends and colleagues that they can later exploit on behalf of their clients. $" 368$

Former public office holders often have access to information about policy formulation and decision-making which other members of the public do not. This can result in an "undue advantage", ${ }^{369}$ given that they potentially have access to items such as confidential information which gives them an edge over competing interests in the political sphere.

\footnotetext{
${ }^{365}$ Richard L Hasen "Lobbying, Rent-Seeking, and the Constitution" (2012) 64 Stan L R 191 at 198; Matthew D Hill, G W Kelly, G Brandon Lockhart and Robert A Van Ness "Determinants and Effects of Corporate Lobbying" (28 June 2013) Social Science Research Network <www.ssrn.com> at 2.

${ }^{366}$ Benjamin M Blau, Tyler J Brough, Diana W Thomas "Corporate Lobbying, Political Connections and the 2008 Troubled Asset Relief Program” (30 September 2011) Social Science Research Network <www.ssrn.com>.

${ }^{367}$ Conor McGrath "The Ideal Lobbyist: Personal Characteristics of Effective Lobbyists" (2006) 10 JCOM 67 at 74.

368 Jordi Blanes i Vidal, Mirko Draca and Christian Fons-Rosen "Revolving Door Lobbyists" (August 2010) Centre for Economic Performance <cep.lse.ac.uk> 2.

${ }^{369}$ OECD Lobbyists, Governments and Public Trust, Volume 1: Increasing Transparency through Legislation (OECD Publishing, 2009) at 133.
} 
These advantages have led to a trend known as the "revolving door" 370 phenomenon, whereby former public officials regularly take up lobbying roles after leaving employment in the public service. Recent studies have shown that these ex-officials are much more successful than other lobbyists in securing favourable outcomes. ${ }^{371}$ This gives an impression of undue influence, and warrants disclosure.

Despite this argument, the Lobbying Disclosure Bill did not include a provision to require lobbyists to disclose whether or not they have been a public office holder in the past. In the United States, lobbyists are obliged include this information in their initial registration returns if they have held one of the covered executive or legislative offices described in the Lobbying Disclosure Act 1995 in the last 20 years. ${ }^{372}$ A similar provision exists in the Canadian Lobbying Act $1985 .{ }^{373}$ If the Parliament of New Zealand moves to regulate lobbyists in the future, a provision of this nature should be considered.

\section{Disclosure of designated public office holder communications}

Theoretically, imposing additional reporting requirements on lobbyists who communicate with key decision-makers provides an increased degree of transparency over significant lobbying activity. Designated public office holders are those which command powerful influence and political decision-making capabilities. A provision to this effect has merit, but the Canadian equivalent has been criticised as burdensome and difficult to implement.

As described, the Canadian approach requires reports to be submitted on a monthly basis for those lobbyists who carry out this form of lobbying activity. This is a heavy administrative burden. In addition to this, the monthly reporting requirement for designated public office holder interactions are used more widely for "consultants as a marketing tool" ${ }^{, 374}$ than they are for increasing the amount of information available to the public about lobbying activities. The potential merit of additional designated public office holder disclosure provisions must be measured against any extra burdens that this would place on registrants. The monthly reporting requirement imposed by the Lobbying Act 1985 is burdensome and does not necessarily increase the amount of information available on specific instances of lobbying, in large part due to the delay between the filing of the report and its later publication on the register. ${ }^{375}$

As with other areas of lobbying legislation, a lack of clarity in drafting can have a detrimental effect on civic engagement. ${ }^{376}$ In Canada, an Interpretation Bulletin was published by the Office of the Commissioner of Lobbying in 2009 which attempted to

\footnotetext{
${ }^{370}$ Robert H Mundheim "Conflict of Interest and the Former Government Employee: Rethinking the Revolving Door” (1981) 14 Creigh L R 707.

${ }^{371}$ Jordi Blanes i Vidal, Mirko Draca and Christian Fons-Rosen "Revolving Door Lobbyists" (August 2010) Centre for Economic Performance <cep.lse.ac.uk> 3.

${ }^{372}$ Lobbying Disclosure Act 19952 USC $\$ 1603$ (b)(6).

${ }^{373}$ Lobbying Act RSC 1985 c55, ss 5(2)(h.1), 7(3)(h).

${ }^{374}$ Lobbyists who file regular reports disclosing interactions with key decision-makers are presumably influential and thus sought after by clients. Kim Doran "A Lobbyist's Observations on the Lobbying Act" (2010) 33 Canadian Parl Rev 24 at 25.

${ }^{375}$ Kim Doran “A Lobbyist's Observations on the Lobbying Act” (2010) 33 Canadian Parl Rev 24 at 25.

376 “Designated Public Office Holder Regulations” (17 April 2008) 142 Canada Gaz 750 at 752.
} 
remedy this issue. ${ }^{377}$ It gives a list of positions which are to be considered designated public office holders, but the list is incomplete. Lobbyists can request public office holders to disclose their income or salary bracket to give an indication of designated public office holder status, but as one lobbyist said, "I have yet to figure out how to slip that into the conversation without seeming rude."378

Notwithstanding these criticisms, additional disclosure requirements for lobbyists interacting with designated public office holders have merit. Lobbying regulation attempts to shine a light on decision-making processes, so it is logical that a greater degree of scrutiny should be given to those actors with a great deal of decision-making power. It is possible to modify the Canadian provisions to the New Zealand context in order to mitigate issues raised in the above criticisms. For example, New Zealand is comparatively small and thus it is feasible that an exhaustive list could be devised which included all positions which would fall under the designated public office holder classification. This would remove ambiguity. Such a list should include Ministers and their staff, members of certain committees and executive staff of Ministries and other public service bodies. Additionally, reducing the frequency with which lobbyists must file returns pertaining to lobbying activity with these officials would deal with the criticism that they impose an unfair administrative burden.

\section{D $\quad$ Suggested Provisions}

Chapter 5 surmised that, if possible, lobbying legislation in New Zealand should apply equally to all lobbyists who come under the ambit of the law. This would increase clarity and decrease the possibility of a downturn in civic engagement. However, this should only be attempted if these rules could achieve the transparency necessary for the law to be effective, without unduly burdening any party with bureaucratic burdens. Legislation that could achieve these aims should include the following elements.

A lobbyist should be defined as someone who, for payment, communicates with a public office holder in relation to the development or status of Bills, legislation, amendments or policies, the awarding of financial benefits, or the awarding of contracts, or arranges a meeting between a public office holder and a third party. Public office holders should include Members of Parliament and senior and executive staff of the bodies listed under Schedule 1 of the State Sector Act 1988.

A lobbyist should register if he or she undertakes to carry out two instances of the afore-mentioned type of communication with a public office holder. To avoid doubt, these instances would include e-mails, phone calls, pre-arranged meetings, office drop-ins and any other situation where the lobbyist carries out lobbying communications in a premeditated manner.

Registration would be achieved by the filing of a return with the lobbying authority, which must be received within one month of the commencement of the undertaking. It should include particulars to identify the lobbyist(s), and public offices held by the lobbyist within the past 10 years. It should also include particulars to identify the client, including - to the knowledge of the lobbyist - any controlling interests and

\footnotetext{
377 "The Registry of Lobbyists" (January 2012) Office of the Commissioner of Lobbying of Canada <http://ocl-cal.gc.ca/eic/site/012.nsf/eng/00442.html>.

${ }^{378}$ W Scott Thurlow "Some Observations on the State of Lobbying in Canada" (2010) Canadian Parl Rev 43 at 44.
} 
(where the client is a company) the name of subsidiaries, or companies who own a significant share of the client. The return should also include particulars to identify the subject matter of the communication, the methods used to communicate and the identity of the target of the lobbying activity.

Returns should then be required every three months thereafter, except in situations where no lobbying activity was conducted in that time. If activity was conducted in accordance with the original registration, a return must be filed simply stating that the original return remains accurate. If activity is conducted in this time that differs from the original return, then the return should include information to rectify the register. If activity is conducted within the three months which involved contact with designated public office holders, then the return must include the name of this public official, and the date and subject of the communications which took place. Designated public office holders should include Ministers of the Crown, and executive staff of the bodies listed under Schedule 1 of the State Sector Act 1988.

\section{E Conclusion}

The hypothetical provisions described above require lobbyists to complete a one or two page document every three months. In situations where lobbying was conducted in keeping with the original return, lobbyists need only tick a single box when making a quarterly return. In situations where no lobbying was conducted in the relevant quarter, the lobbyist does not need to file a return at all. Amendments must be made to registers where lobbyists have conducted activity which is different than originally specified, which is clearly necessary in order to maintain the accuracy of the register.

Where contact has occurred with a designated public office holder, the lobbyist must give additional details about this interaction. This is the most onerous component of these recommendations, but still only requires minimal record-keeping and some paperwork. The benefits of this are manifest. As mentioned earlier, designated public office holders are key-decision makers. It follows that designated public office holders are able to make decisions with limited oversight, which increases the need for transparency where these decisions may have been influenced by lobbying activity. Designated public office holder returns are included in quarterly returns, and must include the date, subject and target of the lobbying activity. This would provide greater transparency over instances of lobbying with key decision-makers, without imposing onerous reporting requirements such as the monthly designated public office holder reports required by the Canadian Act.

The recommendations for reform contained in this conclusion arguably meet three of the five criteria for a sound lobbying framework, as espoused by the OECD. It defines actors and activities to be covered, introduces standards and procedures for disclosing information which covers key aspects of lobbying and these go some way to addressing public concerns. The following chapters deal with the two aspects which are thus-far unresolved; namely, enforceable standards of conduct and methods of ensuring compliance. 


\section{PART THREE - ENFORCEMENT}

As stated elsewhere in this paper, the OECD has espoused five requirements for a sound lobbying framework. Again, these are: ${ }^{379}$

- Standards and rules that adequately address public concerns and conform to the sociopolitical and legal context.

- A legislation or regulation that suitably defines the actors and activities covered.

- Standards and procedures for disclosing information that cover key aspects of lobbying such as its intent, beneficiaries and targets.

- Enforceable standards of conduct for fostering a culture of integrity by, for instance, avoiding conflict of interest and providing accurate information.

- A coherent spectrum of strategies and practices that secure compliance with standards and rules.

Part II gives a response to the first three of these requirements. In order to achieve the latter two, any potential lobbying legislation in New Zealand must have an effective lobbying authority to oversee its administration, a code of conduct to which lobbyists are expected to adhere, and suitable sanctions to be imposed on those who do not comply with the register and its associated provisions. These three elements form the basis of the present Part, which is divided accordingly. It is first proposed that a new Office of Parliament should be established to perform the role of Lobbying Authority. A number of suggestions are given as to what form a potential Lobbying Code of Conduct should take. Finally, a range of sanctions are suggested to increase compliance with the proposed lobbying law which achieve this outcome without undue severity.

\footnotetext{
${ }^{379}$ OECD Lobbyists, Governments and Public Trust, Volume 1: Increasing Transparency through Legislation (OECD Publishing, 2009) at 11.
} 
The most superbly-drafted lobbying legislation will be ineffective in the absence of an appointed authority to oversee its administration. Lobbying is a multi-faceted, subtle and technical form of political activity, which means that lobbying legislation must provide for the establishment or appointment of an authority which can put its provisions into effect. Lobbying authorities have a number of common duties. These duties require the authority to act in a capacity which is entirely independent from those who are involved in lobbying activity; specifically, the authority must be insulated from the Executive and the Legislature.

This chapter identifies a number of parties in New Zealand who could potentially fulfil the lobbying authority role, and assesses whether any of these appointments would be suitable. It concludes that an Officer of Parliament would be the best-placed to fill this role. It leaves the question open as to whether an existing officer could act as a lobbying authority, or whether lobbying legislation would necessitate the creation of an additional Office. This chapter argues in favour of the latter, but concedes that this proposition may not find popularity, given the nature of budgetary constraints.

\section{B Lobbying Disclosure Bill}

The Lobbying Disclosure Bill proposed to increase the transparency of governmental decision-making by "establishing a Register of Lobbyists, which is administered by the [Controller and] Auditor-General". ${ }^{380}$ As part of this administrative duty, the Auditor-General was to be charged with establishing and maintaining a Register of Lobbyists that was made available in full to the public on a website (and in other manners and forms deemed appropriate). ${ }^{381}$ In addition to this, the Auditor-General was to be obliged to conduct an investigation into instances of lobbying activity where there is reason to believe that the Lobbying Code of Conduct has been breached. ${ }^{382}$ Finally, the Bill was to give the Officer the power to "issue advisory opinions concerning the enforcement, interpretation or application of [the Bill].",383

\section{Necessary characteristics of lobbying authorities}

Lobbying authorities must have certain characteristics if they are to be effective. Most crucially, they must be independent. Regulatory bodies should be independent of "each other, from executives (such as presidents and governors who may have appointment authority); from legislatures (who may have confirmation, policy, and oversight authority); from political parties, factions and interest groups... ancillary interests... and, of course, from those regulated". ${ }^{384}$ This independence must stretch to cover all aspects of the authority's existence. It should be granted autonomy and discretion in terms of how it achieves its objectives. The authority must be free from actual and perceived interference, which means that those responsible for position appointments and budgetary decisions must also be detached from the listed parties.

\footnotetext{
${ }^{380}$ Lobbying Disclosure Bill 2012 (15-1), cl 3(a).

${ }^{381}$ Lobbying Disclosure Bill 2012 (15-1), cl 10.

${ }^{382}$ Lobbying Disclosure Bill 2012 (15-1), cl 15.

${ }^{383}$ Lobbying Disclosure Bill 2012 (15-1), cl 18.

${ }^{384}$ J Beecher "The Prudent Regulator: Politics, Independence, Ethics and the Public Interest" (2008) 29 Energy L J 577 at 586.
} 
In short, the lobbying authority must be capable and willing to carry out probing and controversial investigations of high-ranking Ministers and public officials without fear or favour.

Independence is clearly necessary for authorities charged with investigating governmental conduct. This necessity has been seemingly overlooked in a number of past and present regulating jurisdictions, which has been the cause of controversy and criticism. For example, the original lobbying law in Canada - the Lobbyists Registration Act 1989 - gave investigatory powers to the Ethics Counsellor, who reported to the Prime Minister. This ultimately meant that investigations were "subject to the direction of the government of the day." 385 Similarly, the Australian Code of Conduct is overseen by a government department (the Secretary of the Department of the Prime Minister of Cabinet). ${ }^{386}$ This has obvious implications for the impartiality of the enforcement of the Code.

In modernity, the Canadian Lobbying Act 1985 is overseen by the Office of the Commissioner of Lobbying. The Commissioner is appointed by Parliament as an independent Agent of Parliament. ${ }^{387}$ In the United States, the Lobbying Disclosure Act 1995 is administered by the Clerk of the House and the Secretary of the Senate. ${ }^{388}$ These offices lack the independence of the Canadian commissioner, but their performance is audited by the Government Accountability Office as part of a wider annual review of the Act. ${ }^{389}$ This helps to ensure that the Clerk of the House and Secretary of the Senate carry out their respective duties with diligence and impartiality.

\section{Officers of Parliament as lobbying authority candidates}

It was the intention of the Lobbying Disclosure Bill to give the supervisory function of the register to the Controller and Auditor-General. The Auditor-General is one of three Offices of Parliament. These Offices are rarely created, currently including only the Controller and Auditor-General, the Ombudsmen and the Parliamentary Commissioner for the Environment. ${ }^{390}$ The suitability of these Offices to act as a lobbying authority depends on a number of considerations. Firstly, are Offices of Parliament sufficiently independent? Secondly, are any of the existing Offices of Parliament capable of performing the functions of a lobbying authority? If not, is there a case to be made for the establishment of a fourth Office?

\section{$1 \quad$ The Officers of Parliament Committee}

A number of mechanisms exist to ensure that Offices of Parliament retain their independence from the legislature and the executive. These include the process by

\footnotetext{
385 A Paul Pross, "Law and Innovation: The Incremental Development of Canadian Lobby Regulation" in O P Dwivedi, Tim A. Mau and Bryon Sheldrick (eds) The Evolving Physiology of Government (University of Ottowa Press, 2009) at 166.

${ }^{386}$ Lobbying Regimes: An Outline (Parliamentary Library, Research Paper 12/04, April 2012) at 6.

387 "About Us" (3 January 2012) Office of the Commissioner of Lobbying of Canada <https://oclcal.gc.ca/eic/site/012.nsf/eng/h_00004.html>.

${ }^{388}$ Lobbying Disclosure Act 19952 USC § 1603(a)(1).

${ }^{389}$ See generally United States Government Accountability Office 2012 Lobbying Disclosure:

Observations on Lobbyists' Compliance with Disclosure Requirements (April 2013) .

${ }^{390}$ Public Finance Act 1989, s 2 (“'Office of Parliament”).
} 
which officers are appointed, their ability to conduct investigations at will and the way in which the respective budgets are allocated.

The independence of the officers of Parliament from the Executive and Legislature is in large part due to the functions of the Officers of Parliament Committee. The creation of that Committee was recommended in a report by the Finance and Expenditure Committee in 1989 as part of a raft of reforms to government oversight. ${ }^{391}$ The Finance and Expenditure Committee had been instructed by the House to determine what measures could be taken to "put the Controller and AuditorGeneral... on the same constitutional basis as the Officers of Parliament" and to "ensure the independent and effective discharge of their duties by the Officers of Parliament". ${ }^{392}$ To achieve this, it recommended the creation of a new committee, one which would "both safeguard the impartial position of the Speaker and provide freedom from the Executive". ${ }^{393}$

As a select committee, the Officers of Parliament Committee was charged with a range of responsibilities pertaining to the operation of officers of Parliament. It is responsible for the Annual Votes of the Officers of Parliament, which gives it some degree of control over the budgetary parameters of the Offices. It is responsible for the appointment of Officers, and is consulted when a proposal arises for the creation of a new Office. The Officers of Parliament Committee is also required to arrange independent audits of the Offices, and scrutinise the way in which the Officers discharge their functions. ${ }^{394}$ In short, the Committee is responsible for the administration of the Offices of Parliament and for insulating them from political influence. For this arrangement to have integrity, the Officers of Parliament Committee must also be independent.

The independence of the Committee is guaranteed through the way in which it is structured. The Officers of Parliament Committee is chaired by the Speaker. ${ }^{395}$ The Speaker is elected by a personal vote of the House, and is expected to act without prejudice (despite having been elected to the position as a Member of Parliament). ${ }^{396}$ The 1989 Finance and Expenditure Committee also recommended that the Committee should be composed of three members from each side of the House, and that the government's representatives should not also be members of the Executive. ${ }^{397}$ The current practice is that all parties are invited to take a role in the Committee. ${ }^{398}$ Though merely a combination of conventions, the structure of the Officers of Parliament Committee is indispensable to the independence of the Offices it administers. However, in order to determine whether one such office could act as an

\footnotetext{
${ }^{391}$ Finance and Expenditure Committee 1989 "Report on the Inquiry into Officers of Parliament" [1987-1990] XVII AJHR I.4B.

${ }^{392}$ Finance and Expenditure Committee 1989 "Report on the Inquiry into Officers of Parliament" [1987-1990] XVII AJHR I.4B at 3.

${ }^{393}$ Finance and Expenditure Committee 1989 "Report on the Inquiry into Officers of Parliament" [1987-1990] XVII AJHR I.4B at 10.

${ }^{394}$ Finance and Expenditure Committee 1989 "Report on the Inquiry into Officers of Parliament" [1987-1990] XVII AJHR I.4B at 10.

${ }^{395}$ Standing Orders of the House of Representatives 2011, SO 198(3).

${ }^{396}$ Standing Orders of the House of Representatives 2011, SO 18-19.

${ }^{397}$ Finance and Expenditure Committee 1989 "Report on the Inquiry into Officers of Parliament" [1987-1990] XVII AJHR I.4B at 10.

${ }^{398}$ David McGee Parliamentary Practice in New Zealand (3rd ed, Dunmore Publishing, Wellington, 2005) at 71 .
} 
independent lobbying authority, it is necessary to determine whether the Committee has demonstrated an ability to discharge its functions independently and effectively.

\section{$2 \quad$ The appointment of officers}

Officers must have the full confidence of the House to act impartially and with competence. To achieve this, a stringent appointment process has been established. In 2002, the Officers of Parliament Committee set out a procedure intended to "be a guide" 399 for making appointments. It requires the Speaker to begin consultations with all parties represented in the House six months before a term of an existing Officer is due to end.

Members of Parliament can put forward names for appointment, which are ultimately sorted through by the Committee with consultation with the responsible Government Minister (the Treasurer for an Auditor-General, the Minister of Justice for an Ombudsman, and the Minister of the Environment for a Parliamentary Commissioner for the Environment). A proposal for the appointment of an Officer will not go before the House until it receives the unanimous support of the Committee members. In the event that a full quorum cannot be attained, the Speaker can consent to an appointment if it is seen as in the public interest and that the opposing parties represent a "small minority of the members of Parliament." 400 The Acts responsible for the creation of the three offices also impose rules over appointment processes. These include stipulations that candidates cannot be MPs or members of local authorities, and cannot hold other offices of trust or profit. ${ }^{401}$

As is the case with the structure of the Committee, these processes are only as strong as the convention which underlies most of them. Despite this, Officer of Parliament framework is fairly robust and independent. It is unlikely that the functions of a lobbying authority would be limited by shortcomings in the processes involved in the appointment of Officers of Parliament.

\section{$3 \quad$ Funding}

Government departments present statements of intent at the outset of each year. These are presented to the House and include "detailed financial information on the department containing properly prepared forecast financial statements and statements of forecast service performance." ${ }^{, 42}$ The process for Offices of Parliament is slightly different. The offices submit their draft statements to the Speaker. These are then considered by the Officers of Parliament Committee, who consider evidence from the Officers and from the Treasury. The Committee then provides comments to be taken into consideration before the final statements are drafted. ${ }^{403}$ Following this, the

\footnotetext{
${ }^{399}$ Officers of Parliament Committee "Procedures for the Appointment of an Officer of Parliament" (November 2002) at 2.

${ }^{400}$ Officers of Parliament Committee "Procedures for the Appointment of an Officer of Parliament" [2002-2005] III AJHR I.15A at 4.

${ }^{401}$ Ombudsmen Act 1975 s 4; Environment Act 1986 s 5; Public Audit Act s 8.

${ }^{402}$ David McGee Parliamentary Practice in New Zealand (3rd ed, Dunmore Publishing, Wellington, 2005) 472.

${ }^{403}$ David McGee Parliamentary Practice in New Zealand (3rd ed, Dunmore Publishing, Wellington, 2005) 472.
} 
statement is recommended for inclusion in a vote in an Appropriation Bill. By convention, the estimates given by the Committee are adopted by the House. ${ }^{404}$

Funding is not always a simple matter for parliamentary offices. A notable example in 2012 culminated in a desperate plea by the Chief Ombudsmen Beverly Wakem for an increase in funding for her office, to avert what she described as workload "crisis". 405 Submitting to the Government Administration Committee, Ms Wakem noted that her office was established to process between 800 and 1,000 cases at any given time. Current complaints were around double this amount, which was affecting the ability of her office to operate effectively and - in one case - even coming to the serious detriment of the health of her staff. ${ }^{406}$ She asked for an increase of $\$ 1$ million in addition to $\$ 8.6$ million already granted to her office. She received $\$ 960,000$ and a direction to employ six more investigators (having requested eight). It is likely that this will not meet the shortfall. During this time the Auditor-General and the Parliamentary Commissioner for the Environment each requested increases to their respective offices' budgets, citing increasing workloads and difficulties in retaining experienced staff. The former had her request denied, whereas the latter was granted a small budgetary increase of $\$ 100,000 .^{407}$

\section{$4 \quad$ The independence of Offices of Parliament}

To date it appears as though the Offices have operated with independence from the executive and legislature. This is despite the fact that most of the mechanisms supporting this system are merely conventional and thus lack the strength of legislation. The creation, appointment and performance of Offices have been unmolested since their inception. Funding can be problematic, but there is no reason to suggest that Offices have received insufficient funding as a result of lack of independence. In this respect, it is clear that Offices of Parliament are capable of acting as an independent lobbying authority.

\section{E Considering existing Offices of Parliament for a lobbying authority role \\ $1 \quad$ Controller and Auditor-General}

The Controller and Auditor-General was originally to be given lobbying authority responsibilities under the Lobbying Disclosure Bill. ${ }^{408}$ The Office describes its purpose as "assurance work" that "improves the performance of, and the public's trust in, the public sector." ${ }^{409}$ However, its primary function is to establish whether public money is being spent appropriately, ${ }^{410}$ and its responsibilities only cover the public sector.

\footnotetext{
${ }^{404}$ David McGee Parliamentary Practice in New Zealand (3rd ed, Dunmore Publishing, Wellington, 2005) at 474.

405 Adam Bennett "Watchdog in Crisis, MPs Told" The New Zealand Herald (online ed, Auckland, 16 February 2012).

${ }^{406}$ Office of the Ombudsman "Responses to Questions from the Government Administration Committee" (23 November 2012).

407 (14 May 2013) 690 NZPD 9859.

${ }^{408}$ Lobbying Disclosure Bill 2012 (15-1), cl 6.

409 "About the Controller and Auditor-General" (16 September 2013) New Zealand Controller and Auditor-General <http://www.oag.govt.nz/about-us>.

410 "About the Controller and Auditor-General" (16 September 2013) New Zealand Controller and Auditor-General <http://www.oag.govt.nz/about-us〉.
} 
This position was reiterated by the Office of the Auditor-General's submission to the Government Administration Committee on the Lobbying Disclosure Bill. Deputy Auditor-General Phillippa Smith raised two broad concerns with the proposal: that the role would be inconsistent with the Auditor-General's constitutional position, and that it could not perform this function without a significant increase in resources. ${ }^{411}$

As noted, the administration of lobbying legislation requires intimate knowledge of lobbying practices and expertise in terms of how the law is implemented. The roles that the Auditor-General's office plays do not bear any relation to those expected of a lobbying authority, aside from the fact that each office has investigatory powers. ${ }^{412}$ The similarities end there. Most significantly, a lobbying authority would have the power to enforce provisions of the law (such as the ability to strike non-compliant lobbyists from the register) which "is not consistent with the role of an auditor". ${ }^{413}$ It would also be required to investigate alleged breaches committed by private citizens and the private sector, which is well outside of the ambit of the Office as drafted in the Public Audit Act 2001. The Auditor-General may only audit public entities ${ }^{414}$ or other entities if they exist for a public purpose and where they ought to be publically accountable. $^{415}$

The sheer dissimilarity between the roles makes the Office of the Controller and Auditor-General a poor choice for a lobbying authority. In the event that it was charged with these responsibilities, the Office believes it would require a significant increase in funding and more inquiry resources. ${ }^{416}$ Although possible, it seems counter-intuitive to pour funding and personnel into an Office which is ill-suited to the role if alternatives are available.

\section{Parliamentary Commissioner for the Environment}

The Office of the Parliamentary Commissioner for the Environment can be ruled-out as a potential lobbying authority for patently obvious reasons. It was set up to "maintain or improve the quality of the environment by providing robust independent advice that influences decisions." 417 This clearly bears no relation to the role of a lobbying authority. ${ }^{418}$

\footnotetext{
${ }^{411}$ The Office of the Controller and Auditor-General "Submission on the Lobbying Disclosure Bill" at 1. 
The Ombudsmen "enhance government accountability to the public" 419 and provide "a safety net when something goes wrong in public administration." ${ }^{, 420}$ A large portion of the Office's work concerns the proper use of the Official Information Act 1982. ${ }^{421}$

As is the case with the other two Offices, the Ombudsman was designed to deal with complaints against public agencies. ${ }^{422}$ This means that it is not particularly wellplaced to investigate breaches of lobbying regulations on the part of private third parties.

There are significant administrative and financial burdens associated with the duties of a lobbying authority. If given to the Ombudsmen, these duties may overwhelm the Office. This is particularly true given the current workload which the Ombudsmen face. In its 2011/12 statement of intent, the Ombudsmen asked for an extension of additional funding to deal with a growing backlog of inquiries. This backlog has been particularly severe following the Christchurch earthquakes and the Pike River mining disaster. $^{423}$

There is no particular reason to recommend the Ombudsman as a suitable lobbying authority. The Office has investigatory functions and has the same level of independence as its counterparts, but has no particular expertise in lobbying or with private actors. If it was to assume the role it would require a significant increase in funding and a broadening of expertise.

\section{F Contemplating a Parliamentary Commissioner for Lobbying}

It is conceivable that another officer of Parliament could be created to fill the role of lobbying authority. As noted earlier, this approach was taken in Canada with the establishment of the Office of the Commissioner of Lobbying of Canada in 2008 (replacing the Registrar of Lobbyists). The creation of an Office is no small matter, however. The Finance and Expenditure Committee suggested that five criteria be considered during deliberations to determine whether an office should be created: ${ }^{424}$

1. An Officer of Parliament must only be created to provide a check on the arbitrary use of power by the Executive.

2. An Officer of Parliament must only be discharging functions which the House of Representatives itself, if it so wished, might carry out.

3. Parliament should consider creating an Officer of Parliament only rarely.

4. That Parliament review from time to time the appropriateness of each Officer of Parliament's status as an Officer of Parliament.

5. That each Office of Parliament should be created in separate legislation principally devoted to that office.

The Cabinet Manual stipulates that Ministers who are considering developing a bill to establish a new officer of Parliament must consult with the Committee at an early

\footnotetext{
${ }^{419}$ Mai Chen Public Law Toolbox (Lexisnexis, Wellington, 2012) at 682.

${ }^{420}$ Mai Chen Public Law Toolbox (Lexisnexis, Wellington, 2012) at 682.

${ }^{421}$ Official Information Act 1982, ss 28-36.

422 Ombudsmen Act 1975, s 13.

${ }^{423}$ Office of the Ombudsmen "2010/11 Supplementary Estimates and 2011/12 Main Estimates” (2011) at 2 .

${ }^{424}$ Finance and Expenditure Committee 1989 "Report on the Inquiry into Officers of Parliament" [1987-1990] XVII AJHR I.4B at 13.
} 
stage. ${ }^{425}$ Although this is a clear direction, on one occasion the Committee was not consulted before a plan to create an Office reached bill form. ${ }^{426}$ Having received notification of the proposal, the Committee then deliberates on the matter and makes recommendations to the House. ${ }^{427}$

As noted in the 1989 report, the creation of offices is a rare event. Only one office has been created since the inception of the Officers of Parliament Committee, and this was largely treated as a long-overdue amendment. ${ }^{428}$ Before the amendment was made, the Auditor-General was an Officer of the Crown, which was a "major statutory anomaly" 429 recognised by all parties in the House at the time, given that it was required to independently audit on behalf of the public. For this reason there is little guidance available as to how the 1989 criteria for the creation of an office might be interpreted.

One of the greatest deterrents for the creation of an additional Office of Parliament comes about as a result of budgetary constraints. While a full appraisal of the costs associated with the establishment of a Parliamentary Commissioner for Lobbying is beyond the scope of this paper, some insight can be gleaned from the total budgetary expenditures for international equivalents. The 2013-14 estimates for the Office of the Commissioner of Lobbying of Canada is currently $\$ 4.42$ million, involving 28 fulltime equivalent employees. ${ }^{430}$ To put this in perspective, the New Zealand 2013-14 Vote Ombudsmen secured $\$ 10.17$ million from the annual budget. ${ }^{431}$ It is submitted that the expense incurred for the establishment Parliamentary Commissioner for Lobbying is tolerable, in light of the fact that its establishment could increase government integrity and improve public confidence in government decision-making at a time where it appears that the latter is particularly low.

\footnotetext{
${ }^{425}$ Cabinet Office Cabinet Manual 2011 at [7.39].

${ }^{426}$ The Committee objected to the creation of a Deputy Parliamentary Commissioner for the

Environment position, on the basis that this was not brought to the Committee's attention. Officers of Parliament Committee "1994/95 Financial Review: Parliamentary Commissioner for the Environment" [1993-96] AJHR I.23C at 127.

${ }^{427}$ David McGee Parliamentary Practice in New Zealand (3rd ed, Dunmore Publishing, Wellington, 2005) 71.

${ }^{428}$ David McGee Parliamentary Practice in New Zealand (3rd ed, Dunmore Publishing, Wellington, $2005) 74$.

${ }^{429}$ Finance and Expenditure Committee 1989 "Report on the Inquiry into Officers of Parliament" [1987-1990] XVII AJHR I.4B at 11.

${ }^{430}$ MP Tony Clement "Office of the Commissioner of Lobbying of Canada 2013-2014: Reports on Plans and Priorities" (2013) Office of the Commissioner of Lobbying of Canada $<$ http://www.oclcal.gc.ca/eic/site/012.nsf/eng/h_00718.html> at 9 .

${ }^{431}$ New Zealand Treasury "Vote Ombudsmen" The Supplementary Estimates of Appropriations and Supporting Information 2012/13 (Volume 5, B.5A) at 82.
} 


\section{Enforcement: Codes of Conduct and Criminal Sanctions}

Included in the OECD's recommendations for effective lobbying frameworks is a requirement for "enforceable standards of conduct for fostering a culture of integrity by, for instance, avoiding conflict of interest and providing accurate information" and a "coherent spectrum of strategies and practices that secure compliance with standards and rules." 432 These typically take form as non-legislative and legislative measures.

\section{A Code of conduct}

Codes of conduct are a useful non-legislative means of contributing towards the objectives of lobbying legislation. They encourage ethical lobbying practices in accordance with a number of core values. In theory, codes can simultaneously help to ensure reputable lobbying activity whilst also reassuring the public that efforts are being made to achieve this. The Lobbying Disclosure Bill would have required the Auditor-General to develop a Lobbyists' Code of Conduct, which would have espoused the behavioural expectations required of lobbyists and a provision to suspend or remove lobbyists from the Register of Lobbyists as a consequence of noncompliance. ${ }^{433}$

\section{$1 \quad$ Self-regulation}

In most countries, the lobbying profession enforces some degree of self-regulation, which often includes the imposition code of conduct. For example, the Public Relations Institute of New Zealand (PRINZ) employs a Code of Ethics to regulate client-practitioner relations and to impose obligations in relation to the public. ${ }^{434}$ In the United Kingdom, the Public Affairs Council (UKPAC) performs a similar role, and has also implemented a register since June 2012. ${ }^{435}$ The International Public Relations Association has a number of codes which relate to the conduct of its members. ${ }^{436}$

These attempts to self-regulate are commendable. Unfortunately, self-regulation naturally precludes independent oversight and enforcement, which are necessary elements of a lobbying framework that is capable of simultaneously increasing governmental integrity and enhancing public confidence. Perhaps the biggest problem with self-regulatory codes of conduct is that they are voluntary and difficult to enforce; "even if [lobbyists] do choose to subscribe to such a code and subsequently are found to have acted contrary to its provisions, they may be required to leave the relevant representative body but can still then continue to practice." ${ }^{437}$ Expulsion is a weak form of enforceability and in some cases it may even be counterproductive as

\footnotetext{
${ }^{432}$ OECD Lobbyists, Governments and Public Trust, Volume 1: Increasing Transparency Through Legislation (OECD Publishing, 2009) at 11.

${ }^{433}$ Lobbying Disclosure Bill 2012 (15-1), (explanatory note).

434 "PRINZ Code of Ethics" (2008) Public Relations Institute of New Zealand <http://www.prinz.org.nz/Site/About/ethics_code.aspx>.

435 "The Register" (2012) United Kingdom Public Affairs Consultants <http://www.publicaffairscouncil.org.uk/>.

436 "The IPRA Code of Conduct" (2011) International Public Relations Association $<$ http://www.ipra.org/about/ipra-codes>.

${ }^{437}$ Conor McGrath "Towards a Lobbying Profession: Developing the Industry's Reputation, Education and Representation” (2005) 5 J Pub Aff 124 at 130.
} 
some lobbyists find increasing popularity with potential clients as their infamy rises. $^{438}$

\section{$2 \quad$ Principles and rules}

There are few differences between the content of state-mandated codes of conduct and their industry-enforced counterparts. Similar values resound throughout international variants.

(a) International Public Relations Association Code of Conduct

The majority of domestic public relations associations derive their codes of conduct from the one employed by the International Public Relations Association. Containing eighteen provisions, those of relevance to lobbying legislation are those which pertain to integrity, dialogue, transparency, conflict of interest, confidentiality, accuracy of information provided, and the avoidance of falsehood and deception, financial inducement (bribery) or improper influence (threats and aggressive behaviour). ${ }^{439}$

(b) Canadian Lobbyists' Code of Conduct

The Canadian Lobbyists' Code of Conduct consists of a set of principles, and a number of derived rules. It requires lobbyists to act with integrity, honesty, openness and professionalism. It has three categories of rules: those pertaining to transparency, confidentially and conflict of interests. The first ensures that lobbyists convey accurate information and disclose their true identity and the identity of their clients. ${ }^{440}$ It also imposes an obligation for lobbyists to divulge their obligations to the public office holder (with respect to the Code and the Lobbying Act). The second requires lobbyists to respect confidentiality and to not use insider information to the disadvantage of their client. ${ }^{441}$ The final category of rules requires lobbyists to avoid conflicts of interests, to disclose them when they arise, and to not attempt to exert improper influence over public office holders. ${ }^{442}$

(c) Australian Lobbyists' Code of Conduct

The Australian code prescribes a number of rules with respect to "principles of engagement with Government representatives." "443 These principles are broadly similar to those contained within the Canadian code. They require lobbyists to be truthful and accurate with information given to Government representatives, ${ }^{444}$ and to disclose relevant identities and their obligations under the Code. ${ }^{445}$ In addition to this, the Australian code contains a broad provision prohibiting lobbyists from acting corruptly, dishonestly or illegally. ${ }^{446}$ The Australian code also includes a novel clause which requires lobbyists to abstain from making "misleading, exaggerated or

\footnotetext{
${ }^{438}$ Conor McGrath “Towards a Lobbying Profession: Developing the Industry's Reputation, Education and Representation” (2005) 5 J Pub Aff 124 at 130.

439 "The IPRA Code of Conduct" (2011) International Public Relations Association $<$ http://www.ipra.org/about/ipra-codes $>$.

${ }^{440}$ (Ca) Lobbyists' Code of Conduct 2007, arts 1-3.

441 (Ca) Lobbyists' Code of Conduct 2007, arts 4, 5.

442 (Ca) Lobbyists' Code of Conduct 2007, arts 6-8.

443 ( $\mathrm{Au}$ ) Lobbying Code of Conduct, cl 8.

${ }^{444}$ (Au) Lobbying Code of Conduct, cl 8b.

445 (Au) Lobbying Code of Conduct, cl 8e.

${ }^{446}$ (Au) Lobbying Code of Conduct, cl 8e.
} 
extravagant claims about... the nature or extent of their access to Government representatives". ${ }^{447}$

(d) European Commission Code of Conduct for Interest Representatives

The rules of the Commission's code are typical of the other lobbyist codes mentioned above. It includes seven rules, including requirements that the lobbyist be truthful and transparent, and to respect confidentiality requirements. ${ }^{448}$ The only meaningful contribution that the Commission's code makes to this comparison is Rule 6, which instructs lobbyists to "not induce EU staff to contravene rules and standards of behaviour applicable to them". 449

(e) Principles and rules - evaluation of international standards

Values pertaining to truthfulness and transparency in lobbying codes of conduct are omnipresent for good reason. These should be included in a New Zealand equivalent to ensure that public officials know with whom they are dealing, and that the information they are being given is accurate. A clause prohibiting improper influence is also advisable; lobbyists cannot ethically resort to methods such as bribery, extortion or blackmail to achieve their ends. A requirement for lobbyists to disclose their obligations under the relevant law and codes and to inform public office holders of their status therein firmly places with the lobbyist the requirement to monitor his or her compliance with the relevant instruments. This would help to avoid situations whereby public officials feel that they need to provide compliance guidance, which can lead to a number of complications. In Canada, this trend has produced overreporting and the presentation to lobbyists of an "unattractive dialectic choice disagree with the [public office holder's] interpretation and risk not meeting with the MP, or acquiesce to their requests despite the fact that they are not grounded in the law or regulations." 450

Finally, the Australian provision stipulating a prohibition on the exaggeration of influence between lobbyists and their targets touches on a broader topic which could benefit from some attention in a code of conduct. One of the consistent themes of this paper - and of lobbying commentary generally - is about the relationship between lobbying and public confidence. The Australian provision goes some way to discouraging behaviour which would damage public confidence in government integrity. It is arguable that this provision, though well-intentioned, is not broad enough. Instead, more general provision prohibiting conduct which would bring the government or the lobbying industry into disrepute would be well-suited to contributing towards the achievement of the goals of lobbying legislation.

\section{Enforcement of codes of conduct}

Regulating jurisdictions must balance the need for effective and robust standards while also having regard for the possibility that unduly strict rules may not cater for

\footnotetext{
447 (Au) Lobbying Code of Conduct, cl 8c.

${ }^{448}$ European Commission "European Transparency Initiative: A framework for relations with interest representatives (Register and Code of Conduct) (27 May 2008) SEC/2008/1926 at 4.

${ }^{449}$ European Commission "European Transparency Initiative: A framework for relations with interest representatives (Register and Code of Conduct) (27 May 2008) SEC/2008/1926 at 4.

${ }^{450}$ W Scott Thrulow "New Obligations of MPs Under the Lobbying Act" (2010) 33 Canadian Parl Rev 46 at 47.
} 
the realities of the industry, and could deter civic engagement for fear of harsh punishment. Enforcement provisions for codes of conduct are useful because they allow for the implementation of "soft" sanctions for lobbyists who have engaged in unethical lobbying activity, as opposed to a default criminal penalty. In any event, most codes of conduct are non-legislative, which naturally constrains the methods of enforcement open to the lobbying authority charged with administration. The exception to this trend is Canada, which has legislated for a code of conduct. ${ }^{451}$

Several sanctions have been made available in regulating jurisdictions as punitive measures to be taken against non-compliant lobbyists. These range in severity and thus can be tailored to the degree of non-compliance with codes and the lobbyist's individual circumstances.

\section{(a) Suspension and deregistration}

If a lobbying authority discovers serious misconduct on the part of a lobbyist, the lobbyist may be temporarily or permanently removed from the register. This means that the lobbyist can no longer legally lobby public office holders. ${ }^{452}$ This is the most obvious form of punishment, and has clear implications for those who rely on lobbying as an important aspect of their occupation.

(b) Reporting

Some codes authorise the lobbying authority to read its findings to Parliament, thus increasing the severity of consequence for those lobbyists found to be in breach of standards of conduct. ${ }^{453}$ The rationale behind this sanction is that it is likely to make public office holders reluctant to deal with the lobbyist in the future. The effectiveness of this sanction is partially undermined by a point made earlier in this chapter. Specifically, that notoriety has increased the popularity of lobbyists with potential clients in other jurisdictions. Despite this reservation, the overall effect of a reporting clause would likely be a deterrent to lobbyists who would otherwise engage in harmful lobbying activity.

Lobbyists must be given an opportunity to speak to their side of an investigation before the lobbying authority before a decision is made. This helps to guarantee a modicum of fairness. ${ }^{454}$

\section{B Criminal sanctions}

Deliberate and severe circumvention of lobbying legislation is rightfully a criminal offence. Parties who knowingly avoid registration are most likely to be those that the legislation was designed to capture; acting in secrecy and without regard to the law, these lobbyists present a threat to governmental integrity and public confidence in government decision-making processes.

\footnotetext{
${ }^{451}$ OECD Lobbyists, Governments and Public Trust, Volume 1: Increasing Transparency Through Legislation (OECD Publishing, 2009) at 81.

${ }^{452}$ Lobbying Disclosure Bill 2012 (15-1), cl 16; (Au) Lobbying Code of Conduct cl 10.3, European Commission "European Transparency Initiative: A framework for relations with interest representatives (Register and Code of Conduct) (27 May 2008) SEC/2008/1926 at 8.

453 "Lobbying Regimes: an Outline" (Parliamentary research paper, April 2012).

${ }^{454}$ Lobbying Disclosure Bill 2012 (15-1) cl 15(4).
} 
It follows that there must be some criminal sanctions available to prosecutors to deter this type of behaviour. However, as noted earlier, undue severity may reduce civic engagement if parties fear that they may find themselves subject to harsh legal retribution for minor mistakes.

\section{$1 \quad$ Offence severity - a comparison}

The Lobbying Disclosure Bill stipulated that an unregistered individual conducting lobbying activity would be subject to a fine not exceeding $\$ 10,000$, and a company or organisation in a similar situation would be charged with a fine not exceeding $\$ 20,000$. $^{455}$ These fines seem insignificant compared to the possible benefits of undetected unregistered lobbying activity; for example, SkyCity stands to make $\$ 42$ million dollars a year with the concessions it secured through the deal it secured with the National Government in 2013. ${ }^{456}$

Under the Canadian Lobbying Act 1985, lobbyists who fail to make returns or provide misleading information are subject to much more onerous punishments. A summary conviction can lead to a fine of up to $\$ 50,000$ and/or a prison term of up to six months, and an indictment can lead to a fine of up to $\$ 200,000$ and/or a prison term of up to two years. ${ }^{457}$ The United States Lobbying Disclosure Act 1995 imposes a $\$ 50,000$ fine for lobbyists who knowingly fail to comply with any of the provisions of the Act. ${ }^{458}$

\section{$2 \quad$ Offence severity - discussion}

It is clear that the fines imposed by the Lobbying Disclosure Bill were insufficient for the purposes of dissuading unethical lobbying activity. Research produced in North America suggests that there is no evidence to suggest that the heightened severity of offences imposed in the States therein have had a detrimental effect on civic engagement. ${ }^{459}$ For this reason it is advisable that any forthcoming lobbying legislation in New Zealand contain - at a minimum - fines of a much greater magnitude than those originally suggested. Provisions imposing prison sentences may be unnecessary at this point.

\footnotetext{
${ }^{455}$ Lobbying Disclosure Bill 2012 (15-1) cl 19(3).

${ }^{456}$ Adam Bennett and John Armstrong “\$350m SkyCity casino deal to be signed off” The New Zealand Herald (online ed, Auckland, 13 May 2013).

${ }^{457}$ Lobbying Act RSC 1985 c44, s 14(1).

${ }^{458}$ Lobbying Disclosure Act 19952 USC § 1605(7).

${ }^{459}$ Virginia Gray and David Lowerly "State Lobbying Regulations and Their Enforcement: Implications for the Diversity of Interest Communities" (1998) 30 State Local Gov Rev 78 at 90.
} 


\section{PART FOUR - LOBBYING LEGISLATION AS RIGHTS LIMITATION}

Legislation introduced to regulate lobbying practices often runs afoul of a variety of fundamental rights. Those jurisdictions which feature lobbying legislation with the same core characteristics as the Lobbying Disclosure Bill (i.e. a compulsory register for lobbyists, and a lobbyists' code of conduct) struggle chiefly with three rights: freedom of expression, ${ }^{460}$ association, ${ }^{461}$ and privacy. ${ }^{462}$ The individual characteristics of the lobbying regime in question and the protection that these rights are afforded in the State concerned alter the degree to which these rights are infringed.

This Part analyses the Lobbying Disclosure Bill with the modifications recommended in Part II in the context of the New Zealand human rights framework. It specifies how the latter part of the paper statement may be achieved. It concludes that the impacts of such regulation on affected rights can be partially mitigated by clarity in drafting, and are otherwise demonstrably justifiable in a free and democratic society.

\footnotetext{
${ }^{460}$ Elizabeth Garrett, Ronald M Levin and Theodore Ruger "Constitutional Issues Raised by the Lobbying Disclosure Act" in William V Luneburg, Thomas M Susman and Rebecca H Gordon (eds) The Lobbying Manual: A Complete Guide to Federal Lobbying Law and Practice (American Bar Association, 2009) at 197.

${ }^{461}$ Vincent R Johnson "Regulating Lobbyists: Law, Ethics and Public Policy" (2006) 16 JLPP 1 at 5.

${ }^{462}$ William V Luneburg and Thomas M. Susman “Lobbying Disclosure: A Recipe for Reform” (2006) $33 \mathrm{~J}$ Legis 32 at 34.
} 


\section{$X \quad$ Analysing Rights Limitations: the "Proportionality Test"}

A Reconciling lobbying legislation with obligations under the New Zealand Bill of Rights Act 1990

New Zealand has no central, codified constitution. Instead, it has an "unwritten constitution" 463 whereby rights and constitutional protections exist within "a mass of legislation, judicial decisions, conventions, and sundry other sources". ${ }^{464}$ The New Zealand Bill of Rights Act 1990 (NZBORA) is the central rights document. Most of the rights contained within the New Zealand Bill of Rights Act 1990 are set forth in very broad terms.

An established process exists for determining the compatibility of draft Bills with the rights affirmed by the NZBORA. Government Bills are delivered to the Ministry of Justice or the Crown Law Office, where they are vetted for NZBORA compatibility before being sent onwards to the Attorney-General. ${ }^{465}$ The Attorney-General then determines whether Bills are consistent with the NZBORA, pursuant to Section 7 of the Act. The rights affirmed by the NZBORA may be limited by law "as can be demonstrably justified in a free and democratic society." ${ }^{, 66}$ Various judicial rulings have expounded this basis for limitations, providing a useful framework for the justifiability of legislative restrictions on human rights in New Zealand. ${ }^{467}$

The NZBORA is largely derived from the Canadian Charter of Rights and Freedoms, ${ }^{468}$ with the notable absence of a judicial inconsistency power in the former. ${ }^{469}$ In drafting the NZBORA White Paper, Geoffrey Palmer noted that this heritage would allow New Zealand courts to "take advantage of the developing jurisprudence of the Canadian Courts. ${ }^{, 470}$ Geoffrey Palmer was correct; the approach of the New Zealand judiciary to rights limitation closely mirrors the Canadian equivalent. The test used in the Canadian courts was first comprehensively espoused in $R v$ Oakes, ${ }^{471}$ and is described as "a demanding test of justification." 472 One contemporary framing of this test in New Zealand reads as follows: ${ }^{473}$

\footnotetext{
${ }^{463}$ Matthew S R Palmer "What is New Zealand's constitution and who interprets it? Constitutional realism and the importance of public office-holders" (2006) 14 Pub L Rev 133 at 135.

${ }^{464}$ Richard Shaw and Chris Eichbaum Public Policy in New Zealand: Institutions, Processes and Outcomes (3rd ed Pearson Publishing, Auckland 2011) at 39.

${ }^{465}$ Mai Chen Public Law Toolbox (1st Edition, Lexisnexis, Wellington, 2012) at 279.

${ }^{466}$ New Zealand Bill of Rights Act 1990, s 5.

${ }^{467}$ The most prominent of which are the reasonings provided by Chief Justice Elias, and Justices Blanchard, Tipping, McGrath and Anderson in the Supreme Court's ruling in $R v$ Hansen [2007] 3 NZLR 1.

${ }^{468}$ Geoffrey Palmer “A Bill of Rights for New Zealand: A White Paper” [1984-1985] I AJHR A.6 at 6.

${ }^{469}$ This was included in the original Geoffrey Palmer "A Bill of Rights for New Zealand: A White Paper" [1984-1985] I AJHR A6, but was removed following recommendations from the Justice and Law Reform Select Committee; Justice Susan Glazebrook "The New Zealand Bill of Rights Act 1990: its operation and effectiveness" (South Australian State Legal Convention, Adelaide, 23 July 2004) at [3].

${ }^{470}$ Geoffrey Palmer "A Bill of Rights for New Zealand: A White Paper" [1984-1985] I AJHR A.6 at 72.

${ }^{471} R v$ Oakes [1986] 1 SCR 103 at [70].

${ }^{472}$ Sujit Choudhry "So what is the Real Legacy of Oakes? Two Decades of Proportionality Analysis under the Canadian Charter's Section 1" (2006) 34 Sup Ct L R 501 at 502.

${ }^{473} R v$ Hansen [2007] 3 NZLR 1 at [64] as per Blanchard J.
} 
1. The objective of the impugned provision must be of sufficient importance to warrant overriding a constitutionally protected right or freedom; it must relate to concerns which are pressing and substantial in a free and democratic society before it can be characterized as sufficiently important.

2. Assuming that a sufficiently important objective has been established, the means chosen to achieve the objective must pass a proportionality test; that is to say they must:

(a) be 'rationally connected' to the objective and not be arbitrary, unfair or based on irrational considerations;

(b) impair the right or freedom in question as 'little as reasonably possible'; and

(c) be such that their effects on the limitation of rights and freedoms are proportional to the objective.

Essentially, the test asks whether "a justified end is achieved by proportionate means." 474

Attorney-General Chris Finlayson, in his report on the Lobbying Disclosure Bill 2012 (15-1), concluded that the Bill was inconsistent with the New Zealand Bill of Rights 1990. ${ }^{475}$ His analysis - conducted on the basis of the proportionality analysis described above - found that the Bill unjustifiably restricted the right to freedom of expression in New Zealand. With respect, this analysis was incomplete; insofar as NZBORA is concerned, the Bill also had implications for the right to freedom of association.

\section{B Preliminary matters}

Before the proportionality of limiting measures of lobbying legislation can be evaluated, it is first necessary to identify the rights in question, and the way in which they are limited. Of the affected rights identified, some effort must be made to ascertain their scope, and the values upon which they are based. ${ }^{476}$ This has been emphasised by the New Zealand courts in a wide range of cases. ${ }^{477}$

\section{$1 \quad$ The right to freedom of expression}

(a) Scope

The right to freedom of expression is affirmed in Section 14 of the NZBORA. It is defined as "including the freedom to seek, receive and impart information and opinions of any kind and in any form." 478 The section was intended to be "basic and of broad scope". ${ }^{479}$ It deliberately avoids providing an exhaustive list of the various

\footnotetext{
${ }^{474} R v$ Hansen [2007] 3 NZLR 1 at [123] per Tipping J.

${ }^{475}$ Report of the Attorney-General under the New Zealand Bill of Rights Act 1990 on the Lobbying Disclosure Bill (House of Representatives 2012) at 5.

${ }^{476}$ Andrew Butler and Petra Butler The New Zealand Bill of Rights Act: A Commentary (LexisNexis NZ, Wellington, 2005) at 75; Noort v Ministry of Transport [1992] 1 NZLR 743 at 750 as per Gallen J.

${ }^{477}$ Ministry of Transport $v$ Noort Police v Curran [1992] 3 NZLR 260 at 279 as per Richardson J; Quilter v Attorney-General [1998] 1 NZLR 523 at 540 as per Thomas J; $R$ v Jefferies [1994] 1 NZLR 290 at 299 per Cooke P.

${ }^{478}$ New Zealand Bill of Rights Act 1990, s 14.

${ }^{479}$ Geoffrey Palmer “A Bill of Rights for New Zealand: A White Paper” [1984-1985] I AJHR A.6 at 79.
} 
actions protected by the right, which leaves a great of space for interpretation. ${ }^{480}$ In Moonen v Film and Literature Board of Review, the forms and kinds of expression which may have protection under s 14 of NZBORA were considered to be "as wide as human thought and imagination."

(b) Values

Of the many core values of the right to freedom of expression, two are of relevance to mandatory lobbying disclosure regimes: the discovery of truth, and democratic integrity.

The conceptual "Marketplace of Ideas" 482 is often attributed to John Stuart Mill's On Liberty. ${ }^{483}$ It describes a largely hypothetical scenario whereby all ideas are considered - notwithstanding the extent to which the idea is truthful, valuable or obscene - by the audience, which discovers the "truth" 484 by varying degrees of consensus. The notion is based on a "classic image of competing ideas and robust debates" ${ }^{485}$ which "presupposes that the right conclusions are more likely to be gathered out of a multitude of tongues than through any kind of authoritative selection" ${ }^{486}$ The merits of the pursuit of truth are self-evident, and were described by Holmes J of the Supreme Court of the United States. He contended, "every year if not every day we have to wager our salvation upon some prophecy based upon imperfect knowledge." 487 There is no level of human life that does not rely on the accuracy of knowledge gained. As a prerequisite for the successful operation of the marketplace of ideas, speakers must be free to express their ideas without fear of retribution.

Although the marketplace of ideas is a useful metaphor for understanding how the right to freedom of expression enables the discovery of truth, readers should be aware of its limitations. In 1984, Stanley Ingber made a compelling case for the inadequacies of the marketplace in its natural form. Most importantly, he suggested that the model assumes a degree of rational decision-making which is "implausible in modern society." 488 This is because a true marketplace requires an open society, which appraises various viewpoints on a purely egalitarian basis. Ingber suggested that this does not occur, and that the values of perspectives are distorted or even overridden by entrenched power structures and ideology. ${ }^{489}$ If true, this would mean that "the dominant 'truth' discovered by the marketplace can result only from the triumph of power, rather than the triumph of reason". ${ }^{490}$ In addition to this, "form or style of presentation can be very important, and there is absolutely no assurance that the truthteller rather than the false-speaker is the superior rhetorician." ${ }^{491}$ These criticisms

\footnotetext{
${ }^{480}$ Andrew Butler and Petra Butler The New Zealand Bill of Rights Act: A Commentary (LexisNexis NZ, Wellington, 2005) at 303.

${ }^{481}$ Moonen v Film and Literature Board of Review [2002] 2 NZLR 9 at [15].

${ }^{482}$ Andrew Butler and Petra Butler The New Zealand Bill of Rights Act: A Commentary (LexisNexis NZ, Wellington, 2005) at 307.

${ }^{483}$ John Stuart Mill On Liberty and Considerations on Representative Government I (Macmillan, New York, 1946) at 13.

${ }^{484}$ Stanley Ingber "The Marketplace of Ideas: A Legitimizing Myth” [1984] Duke L J 1 at 5.

${ }^{485}$ Stanley Ingber "The Marketplace of Ideas: A Legitimizing Myth” [1984] Duke L J 1 at 3.

${ }^{486}$ Associated Press v United States 1 US 362 (1945) at 372.

487 Jacob Abrams v United States 20 US 616 (1919) at 630.

${ }^{488}$ Stanley Ingber "The Marketplace of Ideas: A Legitimizing Myth" [1984] Duke L J 1 at 5.

${ }^{489}$ Stanley Ingber "The Marketplace of Ideas: A Legitimizing Myth" [1984] Duke L J 1 at 15

${ }^{490}$ Stanley Ingber "The Marketplace of Ideas: A Legitimizing Myth" [1984] Duke L J 1 at 15

${ }^{491}$ Harry H. Wellington “On Freedom of Expression” (1979) 88 Yale L J 1105 at 1130.
} 
aside, the concept has remained one of the central values of the right to freedom of expression. $^{492}$

The second relevant value underlying the right to freedom of expression is less abstract - but somewhat related to - the first. The ability of constituents to freely express opinions and information is "indispensable for the formation of public opinion... political parties, trade unions, scientific and cultural societies and, in general those who wish to influence the public". ${ }^{493}$ It enables members of democratic societies to come to informed decisions. Politically, this allows for robust and informed debate on the composition and direction of democratic government. It is also central to the protection of rights, which helps to provide the "stability necessary for society to develop in a peaceful and relatively prosperous manner." ${ }^{494}$ The InterAmerican Court of Human Rights surmised these points stating, "a society that is not well informed is not a society that is truly free." 495

(c) Accepted limitations

Though it is often given primacy over other considerations, the right to freedom of expression is not absolute. Article 19(3) of the International Covenant on Civil and Political Rights provides a useful rule of thumb for determining the legitimacy of restrictions on free speech. ${ }^{496}$ It specifies three criteria which must be met: the limitation must be provided by law (i.e. as a result of formal law-making processes), and necessary ("on a scale between 'useful' and 'indispensable', 'necessary' should be close to 'indispensable"") ${ }^{497}$ and exist to achieve a legitimate aim (including for the protection of other rights, national security and public order). ${ }^{498}$

In practice, freedom of expression is limited in a range of situations. The ICCPR explicitly provides for a limitation on speech which incites war, discrimination, hostility or violence. 499 "Hate expression" 500 is prohibited by the Human Rights Act 1993 (HRA). Section 61 of the HRA makes it a criminal offence for any person to express threatening, abusive or insulting content if it is likely to excite hostility against persons on the basis of their colour, race, or ethnic or national origins. ${ }^{501}$

\footnotetext{
${ }^{492}$ Andrew Butler and Petra Butler The New Zealand Bill of Rights Act: A Commentary (LexisNexis NZ, Wellington, 2005) at 307.

${ }^{493}$ Compulsory Membership in an Association Prescribed by Law for the Practice of Journalism (Advisory Opinion) IACHR OC-5/85, 13 November 1985, at [7].

${ }^{494}$ Agnes Callamard "Expert Meeting on the Links Between Articles 19 and 20 of the ICCPR: Freedom of Expression and Advocacy of Religious Hatred that Constitutes Incitement to Discrimination, Hostility or Violence" (UN HCHR, Geneva, 2 October 2008) at 3.

${ }^{495}$ Santiago A Canton "The Role of the OAS Special Rapporteur for Freedom of Expression in Promoting Democracy in the Americas" (2001) 56 U Miami L Rev 307 at 308.

${ }^{496}$ International Covenant on Civil and Political Rights (adopted 16 December 1966, entered into force 23 March 1976), art 19(3).

497 "Limitations" (2013) Article 19: Defending Freedom of Expression and Information <http://www.article19.org/pages/en/limitations.html>.

${ }^{498}$ Agnes Callamard "Expert Meeting on the Links Between Articles 19 and 20 of the ICCPR: Freedom of Expression and Advocacy of Religious Hatred that Constitutes Incitement to Discrimination, Hostility or Violence" (UN HCHR, Geneva, 2 October 2008) at 5.

${ }^{499}$ Agnes Callamard "Expert Meeting on the Links Between Articles 19 and 20 of the ICCPR: Freedom of Expression and Advocacy of Religious Hatred that Constitutes Incitement to Discrimination, Hostility or Violence" (UN HCHR, Geneva, 2 October 2008) at 5.

${ }^{500}$ New Zealand Human Rights Commission Human Rights in New Zealand Today (Human Rights Commission, Auckland, 2004), Chapter 8.

${ }^{501}$ Human Rights Act 1993, s 61(1).
} 
Another commonly accepted form of expression limitation is the practice of censorship. ${ }^{502}$ Other areas which involve a legitimate restriction on the right to freedom of expression include laws around defamation ${ }^{503}$ and privacy. ${ }^{504}$ Despite its much-vaunted presumption of supremacy, freedom of expression is limited in New Zealand for myriad reasons.

(d) Lobbying legislation as a limit on the right to freedom of expression

Lobbying legislation limits freedom of expression in two broad manners. These limitations arise as a result of the registration and disclosure requirements of typical lobbyist registers. Lobbying is a form of expression, as it involves the imparting of information or opinions between a lobbyist and a public official. The exercise of the right in this manner is afforded some protected under the New Zealand Bill of Rights Act $1990{ }^{505}$

(i) Bar on political expression

Mandatory lobbyist registers prohibit certain types of lobbying activity by unregistered parties. For example, the drafters of the Lobbying Disclosure Bill intended for it to be an offence to "engage in lobbying activity... without being registered as a lobbyist". ${ }^{506}$ The Attorney-General noted that this limited "the ability to express information freely." ${ }^{507}$ It follows that the requirement to register is a prima facie restriction on the right to freedom of expression. ${ }^{508}$

(ii) Chilling effect

Prominent academics and public figures have raised concerns about the potential for lobbying legislation to chill the exercise of the right to freedom of expression. ${ }^{509}$ Two arguments are raised in support of this contention.

The first is made in relation to the privacy of expression. As a stand-alone right, privacy is not enshrined in the NZBORA. However, it is possible that speakers may be deterred from having conversations if their contents were made public. In this respect, disclosure mechanisms could infringe on the right to freedom of expression.

The second argument for the existence of a chilling effect caused by lobbying registers is made on the basis of the "self-censorship" ${ }^{10}$ phenomenon. As mentioned elsewhere in this paper, lobbying legislation regularly struggles to espouse clear parameters to accurately define the types of expression which should be subject to its provisions. "The law cannot be vague, undefined, and totally discretionary: it must be

\footnotetext{
${ }^{502}$ Films, Videos and Publications Classification Act 1993, ss 122-132A.

${ }^{503}$ Defamation Act 1992.

${ }^{504}$ TV3 Network Services Ltd v ECPAT New Zealand Inc [2003] NZAR 501 at [43].

${ }^{505}$ New Zealand Bill of Rights Act 1990, s 14.

${ }^{506}$ Lobbying Disclosure Bill 2012 (15-1), cl 19(2).

${ }^{507}$ Report of the Attorney-General under the New Zealand Bill of Rights Act 1990 on the Lobbying Disclosure Bill (House of Representatives 2012) at 3.

${ }^{508}$ Steven A Browne "The Constitutionality of Lobby Reform: Implicating Associational Privacy and the Right to Petition the Government" (1995) 4 Will \& Mary Bill Rts J" 717 at 743.

${ }^{509}$ Mai Chen Public Law Toolbox (1st ed, Lexisnexis, Wellington, 2012) at 45; New Zealand Human Rights Commission "Submission Re: Lobbying Disclosure Bill” at 5; Office of the Clerk of the House of Representatives "Submission - Lobbying Disclosure Bill" at 2.

${ }^{510}$ New York Times Co v Sullivan 376 US 254 (1964) at 279.
} 
ascertainable and understandable." of communication constitute lobbying activity, and which roles are deemed "lobbyists" for the purposes of the Bill, they will be disinclined to communicate in order to avoid the consequences of non-compliance.

These arguments are fully evaluated in the final element of this analysis. The degree to which they reflect a tangible limitation on the right to freedom of expression is determined, and then the proportionality of these limitations is considered. For now it is enough to note that the implementation of a mandatory registration system for lobbyists would be a prima facie restriction on the right to freedom of expression, because it would affect lobbyists' ability to express information and opinions freely. ${ }^{512}$

\section{The right to freedom of association}

\section{(a) Scope}

The New Zealand Bill of Rights Act 1990 affirms the right to free association under Section 17. The right is typically understood in instrumental terms, as an enabler and protector of trade unions, professional bodies, political parties and countless other groups. ${ }^{513}$ It has an intrinsic relationship to the rights to freedom of peaceful assembly and freedom of speech. ${ }^{514}$

(b) Values

Broadly, the right to freedom of association is "integral to a free human life, to being a free person. Picking one's company is part of living as one likes." ${ }^{, 515}$ It is valuable in itself, because "[a]ssociations of every form provide accommodation for experience, much of it pleasurable." $" 516$

Effective representation is the most relevant value of the right to freedom of association. ${ }^{517}$ The right allows individuals to group together to present a unified perspective to any given audience; this is a particularly valuable ability for minority groups who would otherwise risk being marginalised in decision-making processes. The right is intrinsic to representation in all forms of life, particularly at a public policy level and in employment matters. It "empowers groups of people who

\footnotetext{
511 Ontario Film and Video Appreciation Society v Ontario Board of Censors (1983) 34 CR (3d) 73 at 83.

${ }^{512}$ Report of the Attorney-General under the New Zealand Bill of Rights Act 1990 on the Lobbying Disclosure Bill (House of Representatives 2012) at 3.

${ }^{513}$ This arguably "invites abridgements" of the right. G Kateb, "The Value of Association" in A Gutmann (ed) Freedom of Association (Princeton University Press, Princeton, 1998) at 53, as cited in Paul Rishworth, Grant Huscroft, Scott Optican and Richard Mahoney The New Zealand Bill of Rights (Oxford University Press, Melbourne, 2003) at 354.

${ }^{514}$ Thomas I Emerson "Freedom of Association and Freedom of Expression" (1964) 74(1) Yale L J 1 at 2.

${ }^{515}$ George Kateb "The Value of Association" in Amy Gutmann (ed) Freedom of Association (Princeton University Press, 1998) at 36.

${ }^{516}$ George Kateb "The Value of Association" in Amy Gutmann (ed) Freedom of Association (Princeton University Press, 1998) at 37.

${ }^{517}$ Jan Leighley "Group Membership and the Mobilization of Political Participation" (1996) 58 J Polit 447 at 448.
} 
generally do not have a voice to be heard by the public" 518 The reality of representative democratic government is such that groups who are organised around a coherent perspective are more likely to secure recognition than distinct perspectives put forth by single individuals.

(c) Accepted limitations

The majority of current limitations pertain to criminal activity. Under the current Immigration Act 1987, individuals who are members of organisations which have committed acts of terrorism can be deported by orders signed by the Minister of Immigration. ${ }^{519}$ The Sentencing Act 2002 gives courts the power to impose nonassociation orders if it is satisfied that "the making of the order is reasonably necessary to ensure that the offender does not commit further offences". 520 Additionally, the Summary Offences Act 1981 makes it an offence to habitually associate with convicted thieves, violent offenders and serious drug offenders where this association gives a reasonable inference that it will lead to the commission of a related offence. ${ }^{521}$ Contemporary restrictions generally focus on criminality, though not exclusively. For example, the Commerce Act 1986 prohibits associations created which substantially reduce competition in the market. ${ }^{522}$

(d) Lobbying legislation as a limit on the right to freedom of association

Lobbying registers involve a potential limit on the right to associational privacy; the extent to which this occurs depends on the specific disclosure requirements that apply. As noted in Chapter V, among the basic provisions necessary for an effective register of lobbyists is the disclosure of information pertaining to the identity of lobbyists, clients and relevant controlling interests. The identification and disclosure of these associations does not amount to a limitation of its own accord. However, if the disclosure of this information was likely to reflect unfavourably on parties involved, they may be disinclined to associate. This would have a detrimental impact on the ability of these parties to form associations for effective representation.

This line of reasoning suggests that lobbying disclosure mechanisms amount to a breach of the right to freedom of association by reducing the extent to which lobbyists can associate freely. The final section of this analysis considers the proportionality of this harm against the benefits that it may bestow.

C Is the objective of the impugned provision of sufficient importance to warrant overriding a constitutionally protected right or freedom?

In order for an encroachment into the rights to freedom of expression and association to be defensible, it must "relate to concerns that are pressing and substantial in a free and democratic society." ${ }^{, 523}$ Little guidance can be taken from the courts in regard to what might qualify as "substantial" or "pressing". New Zealand judges have substituted inferential reasoning, or common sense, in determining what is substantial

\footnotetext{
${ }^{518}$ Andrew Butler and Petra Butler The New Zealand Bill of Rights Act: A Commentary (LexisNexis NZ, Wellington, 2005) at 445.

${ }^{519}$ Immigration Act 1987, s 73.

${ }^{520}$ Sentencing Act 2002, s 112.

${ }^{521}$ Summary Offences Act 1981, ss 6-6C.

${ }^{522}$ Commerce Act 1986, ss 27-30

${ }^{523} R$ v Hansen [2007] 3 NZLR 1 at [203] as per McGrath J.
} 
or pressing. ${ }^{524}$ In $R v$ Hansen, Blanchard $\mathrm{J}$ contended that the magnitude of harm caused by the misuse of drugs "is sufficiently well known to be taken into account by a Court without evidence on the subject". ${ }^{525}$ In other cases evidence that "reflects the assertion of general abstractions has sufficed." 526

The objectives of lobbying legislation are fairly consistent between jurisdictions. They commonly include two interrelated elements, which involve increasing the integrity of, and public trust in, government decision-making processes and actors. ${ }^{527}$ These objectives reveal the concerns that such legislation is designed to remedy; specifically, a deficit in either integrity or trust.

Chapter II provided a number of examples where unregulated lobbying activity has caused damage to governmental integrity and public confidence. In order to determine whether a limit may be justifiably placed on NZBORA rights, it is necessary to determine whether these dual mischiefs are pressing and substantial in a free and democratic society.

\section{$1 \quad$ Governmental integrity}

How fundamental is governmental integrity to free and democratic society? Earlier in this paper - in keeping with the approach adopted in recent OECD reports - the concept was used interchangeably with the notion of "good governance". This method is continued here.

The importance of good governance in democracies is often highlighted with reference to the characteristics of poor governance. Governments who fail to meet the principles of good governance regularly reflect a number of undesirable outcomes: a tendency towards the misuse of public resources, a lack of predictable government behaviour, an absence of the rule of law and the crippling of markets. ${ }^{528}$ There is a general consensus that a lack of governmental integrity is "corrosive of economic and social development." ${ }^{, 529}$ It is reasonable to conclude that detractions from government integrity are concerns which are substantial and pressing in a free and democratic society.

\footnotetext{
${ }^{524} R v$ Hansen [2007] 3 NZLR 1 at [67] as per Blanchard J; In Andrew Butler and Petra Butler The New Zealand Bill of Rights Act: A Commentary (LexisNexis, Wellington, 2006), the authors argue that the approach taken Quilter $v$ Attorney-General [1998] 1 NZLR 523 placed too much emphasis on inferential reasoning at the expense of substantial evidence at 129. A similar phenomenon has been identified in Canada and South Africa by D Pinard "Charter and Context: The facts for which we need evidence, and the mysterious other ones" (Osgoode Hall Law School Constitutional Conference, Toronto, 6 April 2001); Moise v Transitional Local Council of Greater Germinston (2001) 11 BHRC $474[19]$

${ }^{525} R v$ Hansen [2007] 3 NZLR 1 at [67] as per Blanchard, J.

${ }^{526}$ Andrew Butler and Petra Butler The New Zealand Bill of Rights Act: A Commentary (LexisNexis, Wellington, 2006) at 129.

${ }^{527}$ OECD Lobbyists, Governments and Public Trust, Volume 1: Increasing Transparency Through Legislation (OECD Publishing, 2009) at 3.

${ }^{528}$ Sam Agere Promoting Good Governance: Principles, Practices and Perspectives (Commonwealth Secretariat, London, 2000) at 5.

${ }^{529}$ Fighting Corruption, Promoting Good Governance (Commonwealth Secretariat, London, 2000) at 1.
} 
In addition to the erosion of public confidence that results from unregulated lobbying which was identified in Chapter II, there appears to be a more general "dissatisfaction with, and lack of confidence in, the functioning of the institutions of democratic government" 530 in modern states. Such a loss of confidence in governmental institutions indicates "public disaffection with the modern world", 531 which is concerning given that these institutions are the "basic pillars of society." moderate degree of trust in government actors by the constituents that they are elected to represent, the functions of the state are curtailed and discontent - even unrest - can result. ${ }^{533}$ These outcomes are undesirable. It follows that any deficit in public confidence in government actors and decision-making processes is both substantial and pressing in a free and democratic society.

It is clear that the dual objectives of lobbying legislation are commendable and related to concerns which are pressing and substantial in a free and democratic society. Few instruments fail this step of the test. ${ }^{534}$ It demonstrates that "some" ${ }^{, 535}$ rights limitation is justifiable on this basis.

\section{The second part of Hansen - the proportionality test}

\section{$1 \quad$ Rational connection}

The first prong of the second element of the analysis seeks a rational connection between the means employed and the objective sought. There is a divergence of views on how this step should be approached in New Zealand. In $R v$ Hansen, Tipping $\mathrm{J}$ was of the view that the instrument must simply logically tend to contribute towards its objective. ${ }^{536} \mathrm{He}$ advocated the approach adopted in the courts of England, which impose a simple threshold criteria to satisfy the rational connection requirement.

In the same case, Blanchard and McGrath JJ supported the process adopted in the Supreme Court of Canada, which asks whether the means are arbitrary, irrational or unfair. ${ }^{537}$ This subjects the provisions in question to a greater degree of scrutiny, and for this reason it is used in this analysis. It is in keeping with the belief that "the requirement of rational connection calls for an assessment of how well the legislative garment has been tailored to suit its purpose." $" 538$

\footnotetext{
${ }^{530}$ Dzmitry Yuran "Public Confidence in Social Institutions and Media Coverage: A Case of Belarus" (M.Sc Thesis, University of Tennessee, 2011) at 9.

${ }^{531}$ Kenneth Newton and Pippa Norris "Confidence in Public Institutions: Faith, Culture or Performance" in Susan J Pharr and Robert D Putnam (eds) Disaffected Democracies: What's Troubling the Trilateral Democracies? (Princeton University Press, 2000) at 53.

${ }^{532}$ Kenneth Newton and Pippa Norris "Confidence in Public Institutions: Faith, Culture or Performance" in Susan J Pharr and Robert D Putnam (eds) Disaffected Democracies: What's Troubling the Trilateral Democracies? (Princeton University Press, 2000) at 53.

${ }^{533}$ Arthur H Miller "Political Issues and Trust in Government: 1964-1970" (1974) 68 Am Polit Sci Rev 951 at 952

${ }^{534}$ Dieter Grimm "Proportionality in Canadian and German Constitutional Jurisprudence" (2007) 57 Toronto L J 383 at 388.

${ }^{535}$ Report of the Attorney-General under the New Zealand Bill of Rights Act 1990 on the Lobbying Disclosure Bill (House of Representatives 2012) at 4.

${ }^{536} R v$ Hansen [2007] 3 NZLR 1 at [125] as per Tipping J.

${ }^{537} R v$ Hansen [2007] 3 NZLR 1 at [64] as per Blanchard J.

${ }^{538} R v$ Edwards Books and Art Ltd [1986] 2 SCR 713 at 770.
} 
This part of the analysis comprises three components. Firstly, are the provisions recommended in this paper carefully designed? Secondly, do these provisions impose a certain and unacceptable degree of arbitrariness? Finally, do they contribute in some general way to the dual objectives of lobbying legislation?

(a) Are the provisions carefully designed, and not arbitrary?

Lobbying disclosure legislation has been thoroughly criticised for being unclear, which may indicate that it has not been carefully designed. A notable example of this took place in October 1953, when a claim against the Federal Regulation of Lobbying Act 1946 was heard in the United States Supreme Court, which was made on the basis that the law was unconstitutionally vague. ${ }^{539}$ This concern over vagueness is reflected in many of the submissions made during the Select Committee process of the Lobbying Disclosure Bill. ${ }^{540}$

At a legislative level, the solution to this issue must come from articulate drafting. It can also be supplemented by the advisory role of a lobbying authority. Careful design must include clear elucidation of to whom the law would apply and what the duties of these persons would entail. The law must not capture parties who are not incidental to its objectives.

The thrust of the provisions recommended by this paper are described in Chapter VII, but are repeated here for quick reference. A lobbyist is someone who, for payment, communicates with public office holders (MPs and senior and executive staff of bodies listed under Schedule 1 of the State Sector Act 1988) with respect to a number of defined topics. Explicit exceptions should include activities of a number of public bodies, including departments of the public service, Crown entities, Parliamentary Counsel Office and any Office of Parliament and also interactions which are transparent already, such as select committee submissions. It is recommendable that these lobbyists must register on the occurrence or intention of a second instance of premeditated lobbying activity within a three-month period. Registration involves the filing of a return with the lobbying authority, which includes particulars to identify relevant parties and controlling interests, the subject matter discussed and the communication method employed. Once registered, lobbyists should be obliged to file quarterly returns which update their status on the register of lobbyists, and also indicate whether they have carried out such activity where the target has been a Designated Public Office Holder (Ministers of the Crown and executive staff of the bodies listed under Schedule 1 of the State Sector Act 1988) and what these instances entailed.

These recommendations target the relevant lobbying parties with precision. This is achieved with limited legal jargon or complicated rules. Lobbying activity is simply defined and excludes ordinary interactions between constituents and representatives. The careful design of these provisions allows the register to capture parties who

\footnotetext{
${ }^{539}$ United States $v$ Harris 347 US 612 (1954) at 620.

${ }^{540}$ SenateSHJ "SenateSHJ Submission on the Lobbying Disclosure Bill" at [10]; Tainui Group Holdings Limited "Submission to the Government Administration Committee on the Lobbying Disclosure Bill" at 4; The Salvation Army "Lobbying Disclosure Bill: Government Administration Committee" at [3.6]; Amnesty International Aotearoa New Zealand "Submission to the Government Administration Committee on the Lobbying Disclosure Bill" at [1.2].
} 
conduct lobbying as a professional activity whilst avoiding the inclusion of ordinary, occasional political participation by constituents.

(b) Contribution towards objectives

To establish whether lobbying legislation contributes towards its objectives (i.e. to increase public confidence and governmental integrity), this section is broken into three sections. The first establishes whether lobbying legislation makes lobbying activity more transparent. Having established this, the second and third sections determine whether this increased transparency would contribute to the dual objectives of lobbying legislation.

(i) Does lobbying legislation make lobbying activity more transparent?

It may seem intuitive to the reader that increased disclosure would by definition increase transparency. This is not necessarily the case. For example, poorly drafted disclosure requirements might make false disclosures possible, which would amount to misinformation and would negate the possibility of increased transparency. It is therefore imperative that the link between lobbying activity and transparency is explored.

In 2006, Raj Chari and Gary Murphy produced a comprehensive study of lobbying law Canada, the United States, the European Union and Germany. They found that a majority of elected representatives, public sector administrators and lobby groups believed that higher regulatory approaches to lobbying activities contributed towards transparency. ${ }^{541}$ In a sweeping overview of mechanisms to increase public trust in government, Pierre-Marc Daingneault concluded that lobbying disclosure provisions "contribute to rendering the bureaucracy more transparent" 542 The United States Government Accountability Office believes that recent lobbying legislation reform has led to "more transparency". ${ }^{433}$ There appears to be a general consensus between lawmakers, academics and public agencies that lobbying disclosure legislation tends to make lobbying more transparent.

(ii) Does increased transparency contribute towards increased government integrity?

Insofar as governmental integrity is concerned, transparency is arguably effective for "prophylactic purposes" "544 against corruption and unethical conduct; "[s]unlight is said to be the best of disinfectants; electric light the most efficient policeman." ${ }^{, 545}$ This is a foundation principle of freedom of information policy, and is based on a presumption that parties are less likely to engage in unethical behaviour if they have

\footnotetext{
${ }^{541}$ Raj Chari and Gary Murphy Examining and Assessing the Regulation of Lobbyists in Canada, the USA, the EU institutions, and Germany (Report for the Ireland Department of the Environment, Heritage and Local Government, October 2013) at 72.

${ }^{542}$ Pierre-Marc Daingneault "Transparency and Accountability: Solutions for Rebuilding Citizens' Trust in Public Institution? An Exploratory Study" (paper presented to $20^{\text {th }}$ International Political Science Association World Congress, Fukuoka, 9-13 July 2006) at 20.

${ }^{543}$ United States Government Accountability Office 2008 Lobbying Disclosure: Observations on Lobbyists' Compliance with Disclosure Requirements (April 2009) at 1.

${ }^{544}$ William V. Luneburg \& Thomas M. Susman "Lobbying Disclosure: A Recipe for Reform" (2006)

$33 \mathrm{~J}$ Legis 32 at 33.

${ }^{545}$ Louis Brandeis "What Publicity Can Do" Harpers Weekly (New York, 29 November 1913) at 10.
} 
reason to suspect it will be made open to public scrutiny. It allows decision-makers to be held to account.

The "SkyCity Deal" scandal serves as an example of how mechanisms to improve transparency in lobbying activities could improve governmental integrity. Pursuant to the provisions recommended in this paper, SkyCity would have had an obligation to register and disclose information pertaining to its lobbying activities, which began well before the Ministry of Economic Development called for expressions of interest with respect to its intention to build a convention centre. As noted in Chapter II, this lobbying activity had a corrosive effect on the integrity of the expression of interest process. If the prior relationship between SkyCity and the New Zealand Government was made public before the tendering process, this would have provided a strong political incentive to ensure that it was conducted impartially and inclusively, to avoid a perception of unethical conduct.

(iii) Does increased transparency contribute towards increased public confidence?

The OECD argues that transparency can reassure citizens that "the government is indeed their government, and is not the private preserve of those who can afford to pay for access." ${ }^{" 546}$ Where transparency serves to highlight the fact that governmental decision-making processes are fair and representative, then this is likely to be the case.

However, transparency can - somewhat counterintuitively - decrease public confidence. This is a phenomenon which can result from ethics laws generally. There is a tendency for ethics laws to draw attention to issues perceived to be detrimental to governmental integrity, thereby undermining public trust in institutes and actors. Mackenzie and Hafken note that in the United States, "[t]he more ethics regulations designed and implemented... the more the air has filled with news - often caustic and depressing news - about government ethics. ${ }^{, 547}$ In the context of lobbying disclosure, it is conceivable that upon publication of the extent to which lobbyists have access to public officials in New Zealand, there may be a decline in public confidence in government integrity.

Despite this caveat, it is probable that there would be a net increase in public confidence following the implementation of lobbying legislation. If lobbying is having a minimally untoward effect on government decision-making processes, then transparency will evince this truth and reassure the public. If unethical lobbying is prevalent, then transparency will bring the force of public scrutiny to bear, which will presumably dissuade this practice going forward.

\section{(c) Rational connection - Findings}

The provisions recommended in this paper which have rights implications are rationally connected to their respective objectives. They are carefully designed, without undue arbitrariness. For the purposes of a rights limitation proportionality

\footnotetext{
${ }^{546}$ OECD Lobbyists, Governments and Public Trust, Volume 1: Increasing Transparency Through Legislation (OECD Publishing, 2009) at 47.

${ }^{547}$ G Calvin Mackenzie and Michael Hafken Scandal Proof: Do Ethics Laws Make Government Ethical? (Brookings Institution Press, Washington DC, 2002), at 112.
} 
analysis, it is appropriate to simply conclude that a lobbyist disclosure regime would contribute in a general way towards its stated objectives.

2 Do the limitations impair the right or freedom in question as 'little as reasonably possible'?

The original Oakes Test required that the measure chosen must impair the right "as little as possible". ${ }^{548}$ This requirement evolved into the less-stringent "as little as reasonably possible" 549 in the Canadian Courts. This approach has been adopted in New Zealand. ${ }^{550}$ In determining whether the minimal impairment requirement has been met, the Courts have considered "whether there was an alternative but less intrusive means of addressing the legislature's objective which would have a similar level of effectiveness." 551

The objectives of lobbying legislation are typically to increase government integrity and restore public confidence in governmental decision-making. There are a number of alternatives available to Parliament. These must be briefly explored in order to determine whether they could achieve these objectives in a manner which was less intrusive on the infringed rights.

(a) Non-legislative alternatives

In its report on the Lobbying Disclosure Bill, the Government Administration Committee recommended that it should be substituted by three changes to the parliamentary practice. The first was that Standing Orders concerning contempt of the House and Bribery of MPs should be review in tandem with the development of guidelines for MPs on handling communications. ${ }^{552}$ Further to this, the Committee recommended that the House: ${ }^{.53}$

Require the regulatory impact statements and explanatory notes of parliamentary bills to include details of the non-departmental organisations consulted during the development of related policy and legislation

Encourage the proactive release of policy papers to make the policy-making process more transparent.

These measures appear wide-reaching but would almost certainly fail to meet the degree of transparency envisaged by proponents of lobbying legislation due to a general lack of transparency and legal enforceability.

Under these rules, MPs would be encouraged to voluntarily disclose the identities of major lobbyists. This is unhelpful, given the reasonable assumption that those instances of lobbying most prone to reducing public trust or government integrity are also those instances where the parties involved will be least inclined to disclose its occurrence (due to strong political disincentives). The instances of damaging lobbying described in this paper stemmed partially from a reluctance felt by public officials to disclose the extent and nature of their dealings with lobbyists. It is unlikely that a

\footnotetext{
${ }^{548} R$ v Oakes [1986] 1 SCR 103.

${ }^{549} R v$ Chaulk [1990] 3 SCR 1303 at 1341.

${ }^{550} R v$ Hansen [2007] 3 NZLR 1 at [126] per Tipping J, [217] per McGrath J.

${ }^{551} R v$ Hansen [2007] 3 NZLR 1 at [217].

${ }^{552}$ Lobbying Disclosure Bill 2012 (15-1) (select committee report) at 4.

${ }^{553}$ Lobbying Disclosure Bill 2012 (15-1) (select committee report) at 4.
} 
proposition for lobbying regulation which does not incorporate legal enforceability or vest investigatory and punitive powers in a lobbying authority will meet the transparency objectives of lobbying legislation.

(b) Modified legislative alternatives

Legislative responses to lobbying regulation invariably include some form of a lobbyists' register. A register of lobbyists can only be meaningful if a number of key pieces of information are disclosed. ${ }^{554}$ These requirements form the absolute minimum for an effective register, and include information to identify the interest represented, the object of the lobbying activity, and the government institutions being lobbied. The provisions suggested in this paper are in keeping with these minimum necessities.

\section{$3 \quad$ Are the effects of the limitation of rights and freedoms proportional?}

In the influential Oakes decision, Dickson CJC explained the significance of this step of the test: ${ }^{555}$

Even if an objective is of sufficient importance, and the first two elements of the proportionality test are satisfied, it is still possible that, because of the severity of the deleterious effects of a measure on individuals or groups, the measure will not be justified by the purposes it is intended to serve. The more severe the deleterious effects of a measure, the ore important the objective must be if the measure is to be reasonable and demonstrably justified in a free and democratic society.

To enable a full proportionality enquiry, the effects of the limiting measure on the integrity of the affected right must be calculated to the most accurate degree available. Of course, it must be remembered that "uncertainty reigns" due to the impossibility of predicting the outcome of any future event (particularly those events with as many variables as legislation limiting the rights of an entire nation). With this difficulty in mind, the proportionality analyses for the right to freedom of expression and association are conducted as follows. Firstly, the impact of registration requirements on freedom of expression is considered. The second part of this analysis considers the relationship between disclosure, privacy invasions and collateral chilling effects on the freedoms of expression and association.

\section{(a) Lobbying legislation as a bureaucratic limit on expression}

It is a contention of this paper that the bureaucratic burdens imposed by the registration and reporting requirements of lobbying regimes do not unreasonably limit the variety or regularity of this type of expression.

This argument can be evinced by way of an example. Professional lobbying is a resource-intensive activity. It requires a great deal of time and often necessitates expertise on the part of the lobbyist. This is true of both ends of the scale, including high-profile lobbying between corporates and ministers, and of small business owners

\footnotetext{
${ }^{554}$ OECD Lobbyists, Governments and Public Trust, Volume 1: Increasing Transparency through Legislation (OECD Publishing, 2009) at 58.

${ }^{555} R$ v Oakes [1986] 1 SCR 103 at 140.

${ }^{556}$ D Pinard "Uncertainty and Risks: Evidence in Constitutional Litigation" (paper presented at Annual Convention of the Canadian Institute for the Administration of Justice, Victoria BC, October 2000) at 4.
} 
who are in regular contact with local MPs. ${ }^{557}$ It seems patently unlikely that this activity would cease due to the addition of a negligible amount of paperwork, though it may be reduced to a minor extent. The lobbyist is in a position to know the relevant information to meet disclosure requirements, which means that the filing of registrations and returns should be an expedient process. It is improbable that this would take more than a handful of minutes to finish, and the process is cost-free if completed online. The limited empirical research available on the effect of registration requirements on expression have found no evidence to suggest that it has had a negative impact on the amount and diversity of parties conducting lobbying activity. ${ }^{558}$

As a counterweight to this, some lobbyists find that the bureaucratic burdens imposed by registers have their own rewards; namely, legitimacy. Prominent commentators have noted that lobbyists use registers as a "marketing tool", 559 because they give the appearance of status and legitimacy to the interest represented. This is particularly true of smaller interest groups who struggle to achieve notable publicity.

It is reasonable to conclude that the prima facie limit on freedom of expression imposed by registration requirements is insignificant. By contrast, registration provisions stand to materially increase governmental integrity and public confidence in government decision-making processes. The provisions are proportional in this respect.

\section{(b) Lobbying disclosure and chilling effects}

As noted earlier in this chapter, it is possible that lobbying legislation could result in chilling effects on the rights to freedom of association and expression. If extant, these chilling effects would result from the lack of privacy inherent in disclosure requirements, and from the so called "self-censorship" 560 effect. These limits must be appraised in full in order to determine their respective proportionality. This section concludes that these limits are negligible and justifiable in light of the beneficial objectives of lobbying legislation.

(i) Lobbying disclosure and privacy of expression

There is no provision to affirm the right to privacy in the NZBORA. However, an invasion of privacy can have an ancillary effect on other rights, which makes it a valid consideration in proportionality enquiries. It is accepted that privacy is an essential element of some forms of expression. For example, the secret recording of information may infringe the right on the basis that parties "might alter the content of [their] communication or might lead [parties] to decide not to impart information or

\footnotetext{
${ }^{557}$ This is distinct from one-off or infrequent contact between private citizens and their constituents, who may contact representatives at will, at minimal expense.

${ }^{558}$ David Lowerly and Virginia Gray "How some rules just don't matter: The regulation of lobbyists" (1997) 91 Pub Choice 139 at 145; Virginia Gray and David Lowerly "State Lobbying Regulations and Their Enforcement: Implications for the Diversity of Interest Communities" (1998) 30 State Local Gov Rev 78 at 90; Clive S Thomas and Ronald J Hrebenar "The Regulation of Interest Groups and Lobbying in the Fifty States: Some Preliminary Findings" (paper presented at the Annual Meeting of the Midwest Political Science Association, Chicago, Illinois, 18 April 1991).

${ }^{559}$ Kim Doran “A Lobbyist's Observations on the Lobbying Act" (2010) 33 Canadian Parl Rev 24 at 25.

${ }^{560}$ New York Times Co v Sullivan 376 US 254 (1964) at 279.
} 
opinions at all." 561 This is true of private communications between individuals, particularly where it involves elements of intimacy.

It is clear that intimate or personal conversations between ordinary citizens are distinct from lobbying communications. However, "speech activities directed at the public in general or specific sectors thereof may require anonymity for the speaker in order to ensure full-bodied debate... without that anonymity, speech may not occur for fear of harassment or other adverse consequences. ${ }^{, 562}$ In other words, the privacy of freedom of expression in the public sphere must be accorded some protection in order to reinforce the values of democratic integrity and truth-seeking which underlie the right. It is this argument that forms the basis of the allegation that the mandatory disclosure of lobbying communications may have a general chilling effect on this form of expression.

There is no empirical evidence to suggest the existence of a noteworthy chill on freedom of expression in states where disclosure regimes are in place. In Citizens United v Federal Election Commission, ${ }^{563}$ the Supreme Court of the United States held that obligations to disclose the identities of lobbyists engaged in campaign financing had produced no measurable chill on the right to freedom of expression. ${ }^{564}$

Furthermore, it is the contention of this paper that the privacy of lobbying expressions should be given little weight. The right to freedom of expression does not automatically extend to a right to private public speech. Indeed, the values underlying the right to freedom of expression seem to point to a need for such communications to be made public. For example, it has been established that freedom of expression enables democratic integrity by giving access to information necessary to keep the public informed on matters of governance (i.e. the right to seek information as an aspect of freedom of expression). ${ }^{565}$ "The concept of an open government is the direct emanation from the right to know, which seems to be implicit in the right of free speech and expression". ${ }^{566}$ Lobbying activity is carried out with senior public officials and government representatives with the intention of altering governmental decisionmaking processes. This has relevance to all constituents and thus must be disclosed to enable informed political participation. ${ }^{567}$ In this sense it appears as though lobbying disclosure requirements might be understood as a contributor to freedom of expression, as well as a detractor.

On its face, it seems possible that a reduction of privacy in lobbying activities could chill this form of expression, notwithstanding the issues raised in the above paragraph and the fact that there is little evidential foundation to support this claim. However, a lack of evidence indicates that if this limitation does exist in regulating jurisdictions, it is on a miniscule scale. This limitation would be proportionate, particularly given the

\footnotetext{
${ }^{561}$ Andrew Butler and Petra Butler The New Zealand Bill of Rights Act: A Commentary (LexisNexis NZ, Wellington, 2005) at 322.

${ }^{562}$ William V Luneburg "Anonymity and Its Dubious Relevance to the Constitutionality of Lobbying Disclosure Legislation" 19 Stanford L Pol Rev 69 at 70.

${ }^{563}$ Citizens United v Federal Election Commission 558 US 310 (2010).

${ }^{564}$ Citizens United v Federal Election Commission 558 US 310 (2010) at 341.

${ }_{565}^{56}$ New Zealand Bill of Rights Act 1990, s 14.

${ }^{566}$ S.P. Gupta v President of India and Ors [1982] AIR (SC) 149 at 234.

${ }^{567}$ William V Luneburg "Anonymity and Its Dubious Relevance to the Constitutionality of Lobbying Disclosure Legislation” 19 Stanford L Pol Rev 69 at 70.
} 
beneficial outcomes of lobbying legislation and the likelihood that the limiting provisions would also contribute towards the right to freedom of expression.

\section{(ii) Lobbying disclosure and associational privacy}

There is no judicial or legislative reference to the right to associational privacy in New Zealand. The United States Supreme Court has held that the "inviolability of privacy in group association may in many circumstances be indispensable to preservation of freedom of association". ${ }^{568}$ In the United States context, the limiting provision was nonetheless justified unless it could be demonstrated that the disclosure of associations was "likely to cause violence or threats of violence." ${ }^{569}$ This high threshold is unlikely to give pause to the disclosure of lobbyists' and clients' identities.

In the influential text The New Zealand Bill of Rights, the authors foresee "little difficulty" ${ }^{, 570}$ in justifying the disclosure of campaign contributions where these would reveal associations between contributors and recipients. A similar conclusion would likely be met with respect to lobbying activities.

\section{(iii) Lobbying disclosure and self-censorship}

As noted earlier in this chapter, self-censorship may act as a limit on the right to freedom of expression where the law is unclear or vague. Lobbyists could act to protect themselves from the legal consequences of non-compliance with regulatory provisions by reducing their lobbying activities. This concept was well-espoused by Brennan $\mathrm{J}$ in New York Times Co v Sullivan, ${ }^{571}$ who believed that law which limits human rights but does not clearly articulate the extent to which it does so may cause the public to "steer far wider of the unlawful zone", ${ }^{572}$ thus abridging the right further than intended.

In the context of lobbying legislation, self-censorship could result from legislation which was unnecessarily complex, requiring legal comprehension and bureaucratic competency. It is possible that some lobbyists would avoid lobbying altogether for fear of unknowingly breaching the law. A reasonable extension of this line of reasoning leads to the conclusion that this phenomenon would affect those lobbyists who are less well-resourced, as they could not draw from funds and legal counsel as a means of clarifying their legal obligations. ${ }^{573}$

In 1998 a comprehensive study was conducted by Virginia Gray and David Lowerly on lobbying regulations in the United States and their impacts on the diversity of lobbyists. ${ }^{574}$ At the time, the relevant statutory instruments were much more sophisticated (and thus harder to understand) than those suggested in the LDB or this

\footnotetext{
${ }^{568}$ National Association for the Advancement of Colored People v Alabama 357 US 449 (1958) at 462.

${ }^{569}$ National Association for the Advancement of Colored People v Alabama 357 US 449 (1958) at 462.

${ }^{570}$ Paul Rishworth, Grant Huscroft, Scott Optican and Richard Mahoney The New Zealand Bill of Rights (Oxford University Press, Melbourne, 2003) at 359.

571376 US 254 (1964) at 279.

${ }^{572}$ New York Times Co v Sullivan 376 US 254 (1964) at 279.

${ }^{573}$ Virginia Gray and David Lowerly "State Lobbying Regulations and Their Enforcement: Implications for the Diversity of Interest Communities" (1998) 30 State and Local Gov Rev 78 at 80.

${ }^{574}$ Virginia Gray and David Lowerly "State Lobbying Regulations and Their Enforcement: Implications for the Diversity of Interest Communities" (1998) 30 State and Local Gov Rev 78.
} 
paper. ${ }^{575}$ It follows that if modern legislation was likely to create a self-censorship impingement on the right to freedom of expression, then this trend would have been amplified in the United States in 1998 and thus present in the results of the study conducted by Gray and Lowerly. The authors concluded that their null hypothesis was the most accurate. In other words, rigorous lobbying regulation had "little impact on the diversity of organised interests found within state interest communities." ${ }^{576}$ It found that the effects of regulation were "negligible" 577 in terms of the numbers of lobbyists who were not-for-profits, institutions, membership groups and associations. Though hardly definitive, this tends to support the view that lobbying legislation similar to that proposed in this paper is unlikely to precipitate a trend self-censorship, given that these groups would be those most affected.

The self-censorship phenomenon can be avoided by the provision of clear drafting which is free of complex legal jargon. The addition of a lobbying authority charged with an advisory interpretation function also means that lobbyists can achieve certainty about their obligations under the law without resorting to paying for costly legal advice. It is possible that self-censorship could occur notwithstanding these mitigating factors. However, it is likely to amount to a very small limitation on the free exercise of the right to freedom of expression and would be more than offset by the beneficial effects of lobbying legislation. In this context, the chilling effect described appears to be proportionate.

\section{E Conclusions}

The effects of lobbying legislation on the rights to freedom of expression and association are overstated. There is no evidence to suggest that these limits have been significant in the experience of overseas jurisdictions.

Arguments made against registration and disclosure requirements on purely principled bases appear flawed. Expression is augmented by disclosure in the sense that it facilitates the ability of the public to seek and receive information relevant to democratic integrity. It is unrealistic to expect privacy in associations where these are high-profile relationships within the public sphere.

The provisions recommended in this paper curtail the exacerbating effects of vague or unduly severe legislation. The limits imposed are not arbitrary or irrational, and contribute towards an increase in governmental integrity and public confidence. They are minimal, and the detrimental effects on the rights are proportional to these objectives. In short, registration and disclosure requirements imposed by provisions such as those advocated here are justifiable in a free and democratic society.

\footnotetext{
${ }^{575}$ Not only did lobbying legislation differ wildly between states and the federal government, but it was often much more complex and required conformity to more onerous and technical reporting schemata. Paul Flannery "Lobbying Regulation in the EU: A Comparison with the USA \& Canada" (2010) 20 Soc Polit Rev 70 at 74.

${ }^{576}$ Virginia Gray and David Lowerly "State Lobbying Regulations and Their Enforcement: Implications for the Diversity of Interest Communities" (1998) 30 State and Local Gov Rev 78 at 89.

${ }^{577}$ Virginia Gray and David Lowerly "State Lobbying Regulations and Their Enforcement: Implications for the Diversity of Interest Communities" (1998) 30 State and Local Gov Rev 78 at 89.
} 


\section{Summary}

The Lobbying Disclosure Bill was rejected by the Government and Administration Committee for good reason. It contained a number of drafting deficiencies which would have caused implementation issues and disproportionate limits on one or more human rights.

The most significant shortcoming of the Lobbying Disclosure Bill arose from the way that it defined relevant parties. Of particular concern was the fact that it would capture all paid lobbyists, including those who are less likely to conduct harmful lobbying activity (such as small business owners). This would mean that private citizens could incur obligations resulting from a single encounter with their democratic representative, which has negative implications for civic engagement. As discussed, an obligation of this manner has implications for the rights to freedom of expression and association. Additionally, the Bill only imposed registration obligations for those lobbyists who carried out activities with respect to Members of Parliament and their staff. This definition did not give enough consideration to the relationships which often exist between lobbyists and other public officials.

Other inadequacies of the Bill included the designation of the Auditor-General as the lobbying authority, as this role is not well suited to the office. Furthermore, the reporting requirements contained in the Bill were not optimised to ensure that the Register of Lobbyists would deliver the greatest degree of transparency in return for the smallest possible bureaucratic burden. Finally, the enforcement mechanisms (criminal and otherwise) contained in the Bill were not well-equipped to deal with the wealthy and influential lobbyists to whom harmful lobbying activities are often attributed.

Despite these misgivings, the objectives of the Lobbying Disclosure Bill were commendable. Several instances of harmful lobbying activity have come to light in New Zealand in recent years. It is likely that this is merely the tip of the iceberg, given that the lobbying industry generally operates behind closed doors.

A number of small alterations to the way in which lobbyists are defined would enable an instrument such as the Lobbying Disclosure Bill to dissuade harmful lobbying while allowing ordinary activity to continue without significant impediments. By creating an expanded and exhaustive list of officials with whom lobbying is a registerable activity, a similar Bill could cover a wider variety of influential lobbying activities without becoming unmanageably vague. These definitional alterations deliberately exclude infrequent contact with public officials and government representatives, which would give a clear indication to private citizens that their own lobbying activities would not bring them under the ambit of the law.

In the event that lobbying law comes before Parliament once more, reporting requirements should be tailored to ensure maximum efficiency at minimum cost. Registered lobbyists should only be obliged to file reports when the nature of their activities materially alters. One exception to this rule should be included, which would require lobbyists in contact with key decision-makers (such as ministers) to produce reports on a more regular basis. This would allow the public to be better informed about instances of lobbying activity which are more likely to have a significant effect on the public policy landscape. 
It is also suggested in this paper that an additional Office of Parliament could be created to oversee the administration of lobbying legislation. This may come at a significant cost, but it would avoid imposing further burdens on already strained offices. It would also mean that the law would be overseen by an authority with functions and expertise specific to lobbying regulation. This expertise could be utilised to create and govern a Lobbyists' Code of Conduct which is both relevant and enforceable. Criminal sanctions for non-compliance contained in the Lobbying Disclosure Bill should be markedly increased, to deter wealthy and influential lobbyists from deliberately circumventing the law due to a belief that the potential payoff would be worth the risks imposed by otherwise-miniscule fines.

The conclusions delivered in this paper suggest that it is both possible and desirable to enact legislation to effectively regulate lobbyists in New Zealand. It is likely that a great deal of political pressure will be brought to bear on Parliament in the future, following the inevitable publication of instances of harmful lobbying. It is the hope of this author that this pressure will produce a more considered and enthusiastic legislative response. 


\section{Bibliography}

A Cases

$1 \quad$ New Zealand

Field v R [2012] 3 NZLR 1.

Ministry of Transport v Noort, Police v Curran [1992] 3 NZLR 260.

Moonen v Film and Literature Board of Review [2002] 2 NZLR 9.

Noort v Ministry of Transport [1992] 1 NZLR 743.

Quilter v Attorney-General [1998] 1 NZLR 523.

$R$ v Hansen [2007] 3 NZLR 1.

$R v$ Jefferies [1994] 1 NZLR 290.

SkyCity Auckland Ltd \& Anor v Gambling Commission [2008] 2 NZLR 182.

SkyCity Auckland Ltd \& Anor v Gambling Commission HC Auckland CIV-2005-40400136924 August 2006.

SkyCity Auckland Ltd v Gaming Commission \& Department of Internal Affairs HC Auckland CIV 2005-404-000958 22 November 2005.

TV3 Network Services Ltd v ECPAT New Zealand Inc [2003] NZAR 501.

$2 \quad$ Canada

Ontario Film and Video Appreciation Society v Ontario Board of Censors (1983) 34 CR (3d) 73.

$R v$ Chaulk [1990] 3 SCR 1303.

$R v$ Edwards Books and Art Ltd [1986] 2 SCR 713.

$R$ v Oakes [1986] 1 SCR 103.

$3 \quad$ United States

Associated Press v United States 1 US 362 (1945).

Citizens United v Federal Election Commission 558 US 310 (2010).

Jacob Abrams, et al. v United States 20 US 616 (1919).

National Association for the Advancement of Colored People v Alabama 357 US 449 (1958).

New York Times Co v Sullivan 376 US 254 (1964).

United States v Harris 347 US 612 (1954).

$4 \quad$ Other Jurisdictions 
Compulsory Membership in an Association Prescribed by Law for the Practice of Journalism (Advisory Opinion) IACHR OC-5/85, 13 November 1985.

Moise v Transitional Local Council of Greater Germinston (2001) 11 BHRC 474.

S.P. Gupta v President of India and Ors [1982] AIR (SC) 149.

B Legislation and Bills

$1 \quad$ New Zealand

Commerce Act 1986.

Crimes Act 1961.

Defamation Act 1992.

Electoral Act 1993.

Employment Relations (Film Production Work) Amendment Bill (299-1).

Environment Act 1986.

Films, Videos and Publications Classification Act 1993.

Gambling Act 2003.

Holidays Act 2003.

Human Rights Act 1993.

Immigration Act 1987.

Lobbying Disclosure Bill 2012 (15-1).

New Zealand Bill of Rights Act 1990.

Official Information Act 1982.

Ombudsmen Act 1975.

Public Audit Act 2001.

Public Finance Act 1989.

Sentencing Act 2002.

Summary Offences Act 1981.

$2 \quad$ Canada

An Act to Amend the Lobbyists Registration Act SC 2003 c 10.

An Act to Amend the Parliament of Canada (Ethics Commissioner and Senate Ethics Officer) SC 2004 c 7.

Federal Accountability Act SC 2006 c 9. 
Lobbying Act RSC 1985 c44.

Lobbyists Registration Act SC 1988 c 53.

$3 \quad$ United States

Cal Gov Code, title 9 § 86100-86300.

Ethics in Government 19785 USC § 109.

Federal Regulation of Lobbying Act Ch 753, 60 Stat 841 (1946).

Foreign Agents Registration Act 22 USC $§ 611$.

Lobbying Disclosure Act 2 USC $§ 1602$.

$4 \quad$ Other jurisdictions

Act on Legislative and Regulatory Lobbying 2006 (PL).

International Covenant on Civil and Political Rights (adopted 16 December 1966, entered into force 23 March 1976).

Lobbying and Advocacy Transparency Law 2012 (Austria).

Transparency of Lobbying, Non-party Campaigning and Trade Union Administration Act 2014 (UK).

C Non-legislative instruments

Cabinet Office Cabinet Manual 2008.

Cabinet Office Cabinet Manual 2011.

Interinstitutional Agreement 2291/2010 on a Common Transparency Register [2009] OJ C $271 \mathrm{E}$.

Lobbying Code of Conduct. (Australia).

Lobbyists' Code of Conduct 2007. (Canada).

Standing Orders of the House of Representatives 2011.

D Hansard

(14 May 2013) 690 NZPD.

(25 July 2012) 682 NZPD.

(28 October 2010) 668 NZPD.

E Government publications

Annual Report of the Ombudsmen: 2011/2012 (The Office of the Ombudsman, A.3, 30 June 2012). 
Cabinet Briefing Paper "New Zealand International Convention Centre" (16 December 2011) P/043/PR011.

David McGee Requests for information regarding the production of The Hobbit and film production generally (Office of the Ombudsman, Ombudsman's opinion 302561 \& 302600, 31 January 2013).

Electoral Commission Towards a Better Democracy (December 1986).

Lobbying Regimes: An Outline (Parliamentary Library, Research Paper 12/04, April 2012) at 2.

New Zealand Treasury "Vote Ombudsmen" The Supplementary Estimates of Appropriations and Supporting Information 2012/13 (Parliamentary Paper, Volume 5, B.5A).

\section{F $\quad$ Appendices to the Journal of the House of Representatives}

"Register of Pecuniary and Other Specified Interests of Members of Parliament: Summary of annual returns as at 31 January 2012" [2008-2011] XVII AJHR J.7.

Finance and Expenditure Committee 1989 "Report on the Inquiry into Officers of Parliament” [1987-1990] XVII AJHR I.4B.

Geoffrey Palmer “A Bill of Rights for New Zealand: A White Paper” [1984-1985] I AJHR A.6.

Officers of Parliament Committee "1994/95 Financial Review: Parliamentary Commissioner for the Environment" [1993-96] AJHR I.23C.

Officers of Parliament Committee "Procedures for the Appointment of an Officer of Parliament" [2002-2005] III AJHR I.15A.

Standing Orders Committee "Review of Standing Orders" [2008-2011] III AJHR I.18B.

G Texts

$1 \quad$ Books and chapters in books

A Paul Pross, "Law and Innovation: The Incremental Development of Canadian Lobby Regulation" in O P Dwivedi, Tim A. Mau and Bryon Sheldrick (eds) The Evolving Physiology of Government (University of Ottowa Press, 2009).

Andrew Butler and Petra Butler The New Zealand Bill of Rights Act: A Commentary (LexisNexis NZ, Wellington, 2005).

Andrew Geddis Electoral Law in New Zealand (2007, Lexisnexis, Wellington).

Arthur Fisher Bentley The Process of Government (Harvard University Press, 1967).

Bertrand Badie, Dirk Berg-Shlosser and Leonardo Morlino International Encyclopaedia of Political Science (Sage Publications, 2011). 
Bradley Smith Unfree Speech: The Folly of Campaign Finance Reform (Princeton University Press, 2009).

Christophe Béné and A Neiland From Participation to Governance (WorldFish, Malaysia, 2006).

Christopher J Kam Party Discipline and Parliamentary Politics (Cambridge University Press, 2009).

Darren Halpin "Pressure Groups and Lobbying" in Rodney Smith, Ariadne Vromen and Ian Cook (eds) Contemporary Politics in Australia: Theories, Practices and Issues (Cambridge University Press, 2012).

David Held Models of Democracy (Stanford University Press, 2006).

David McGee Parliamentary Practice in New Zealand (3rd ed, Dunmore Publishing, Wellington, 2005).

Elizabeth Garrett, Ronald M Levin and Theodore Ruger "Constitutional Issues Raised by the Lobbying Disclosure Act" in William V Luneburg, Thomas M Susman and Rebecca H Gordon (eds) The Lobbying Manual: A Complete Guide to Federal Lobbying Law and Practice (American Bar Association, 2009).

Eric M Ulsaner "Democracy and social capital" in Mark E Warren (ed) Democracy and Trust (Cambridge University Press, 1999).

G Calvin Mackenzie and Michael Hafken Scandal Proof: Do Ethics Laws Make Government Ethical? (Brookings Institution Press, Washington DC, 2002).

G Kateb, "The Value of Association" in A Gutmann (ed) Freedom of Association (Princeton University Press, Princeton, 1998).

John Locke Second Treatise of Government (Hayes Barton Press, 1952).

John Stuart Mill Considerations on Representative Government (Prometheus Publishers, New York, 1991).

Justin Greenwood and Mark Aspinwall (eds) Collective Action in the European Union: Interests and the new politics of associability (Routlege, 1998).

Kenneth Newton and Pippa Norris "Confidence in Public Institutions: Faith, Culture or Performance" in Susan J Pharr and Robert D Putnam (eds) Disaffected Democracies: What's Troubling the Trilateral Democracies? (Princeton University Press, 2000).

Lionel Zetter Lobbying: The Art of Political Persuasion (1st ed, Harriman House, Hampshire, 2008).

Mancur Olson The Rise and Decline of Nations: Economic Growth, Stagflation, and Social Rigidities (Yale University Press, 2008).

Max McCombs, R Lance Holbert, Spiro Kiousis and Wayne Wanta The News and Public Opinion: Media Effects on Civic Life (Polity, Cambridge, 2011). 
Nicky Hager The Hollow Men: A Study in the Politics of Deception (Craig Potton Publishing, Nelson, 2006).

Nicole Gillespie, Robert Hurley, Graham Dietz and Reinhard Bachmann "Restoring Institutional Trust after the Global Financial Crisis" in Roderick M Kramer and Todd L Pittinsky (eds) Restoring Trust in Organizations and Leaders: Enduring Challenges and Emerging Answers (Oxford University Press, 2012).

Paul Rishworth, Grant Huscroft, Scott Optican and Richard Mahoney The New Zealand Bill of Rights (Oxford University Press, Melbourne, 2003).

Raj Chari, John Hogan, Gary Murphy Regulating Lobbying: A Global Comparison (Manchester University Press, 2010).

Richard E Matland "Enhancing Women's Political Participation: Legislative Recruitment and Electoral Systems" in Julie Ballington and Azza Karam (eds) Women in Parliament: Beyond Numbers (International Idea, Stokholm, 2005).

Richard Mulgan and Peter Aimer Politics in New Zealand (Auckland University Press, Auckland, 2004).

Richard Shaw and Chris Eichbaum Public Policy in New Zealand: Institutions, Processes and Outcomes (3rd ed Pearson Publishing, Auckland 2011).

Russell Hardin "Do we want trust in government?" in Mark E Warren (ed) Democracy and Trust (Cambridge University Press, 1999).

Tom Avermaete and Anne Massey Hotel Lobbies and Lounges: The Architecture of Professional Hospitality (Routledge, 2012).

Will Kymlicka Contemporary Political Philosophy (2nd ed, Oxford University Press, 2002).

$2 \quad$ Reports and briefing papers

Consumer and Corporate Affairs Canada Lobbyists Registration Act Annual Report (31 March 1990).

EU Citizens opinion poll on transparency, ethics and lobbying in the EU (briefing paper, EU Citizens, February 2013).

Fighting Corruption, Promoting Good Governance (Commonwealth Secretariat, London, 2000).

Inquiry into the Government's decision to negotiate with SkyCity Entertainment Group Limited for an international convention centre (Office of the Controller and Auditor-General, Independent Assurance Report, February 2013).

John Graham, Bruce Amos \& Tim Plumptre Policy Brief No 15: Principles for Good Governance in the $21^{\text {st }}$ Century (Institute on Governance, 2003).

New Zealand Human Rights Commission Human Rights in New Zealand Today (Human Rights Commission, Auckland, 2004). 
OECD Lobbyists, Governments and Public Trust, Volume 1: Increasing Transparency through Legislation (OECD Publishing, 2009).

OECD Lobbyists, Governments and Public Trust, Volume 2: Promoting Integrity through Self-Regulation (OECD Publishing, 2009).

Raj Chari and Gary Murphy Examining and Assessing the Regulation of Lobbyists in Canada, the USA, the EU institutions, and Germany (Report for the Ireland Department of the Environment, Heritage and Local Government, October 2013).

Sam Agere Promoting Good Governance: Principles, Practices and Perspectives (Commonwealth Secretariat, London, 2000).

Tony Clement Office of the Commissioner of Lobbying of Canada 2013-2014: Reports on Plans and Priorities (Treasury of Canada, 2013).

United States Government Accountability Office 2008 Lobbying Disclosure: Observations on Lobbyists' Compliance with Disclosure Requirements (April 2009).

$3 \quad$ Other texts

Broadcasting Standards Authority Election Programmes Code of Broadcasting Practice (May 2011), Standards E1-4.

Dzmitry Yuran "Public Confidence in Social Institutions and Media Coverage: A Case of Belarus" (M.Sc Thesis, University of Tennessee, 2011) at 9.

H Articles

A F Tyson "A Synopsis of the "Hobbit Dispute" (2011) 36 NZJER 6.

Andrew Geddis "Rethinking the Funding of New Zealand's Election Campaigns" (2007) 3 Pol'y Q 3.

Andrew Geddis "The Electoral (Finance Reform and Advance Voting) Amendment Bill” (2010) 6 Pol'y Q 3.

Andrew Moravcsik, "In Defence of the 'Democratic Deficit': Reassessing Legitimacy in the European Union" (2002) 40 JCMS 603.

Andrew P Thomas "Easing the Pressure in Pressure Groups: Toward a Constitutional Right to Lobby” (1993) 16 Harv JL \& Pub Pol’y 149.

Arthur H Miller "Political Issues and Trust in Government: 1964-1970" (1974) 68 Am Polit Sci Rev 951.

Barbara Burton "Non-standard Work: an Employer Perspective" 42 (2011) 36 NZJER 37.

Belle Zeller "The Federal Regulation of Lobbying Act" (1948) 42 Am Polit Sci Rev 239.

Bernard Walker "How does non-standard employment affect workers? A consideration of the evidence" NZJER 14. 
Bo Rothstein and Jan Teorell "What is Quality of Government? A Theory of Impartial Government Institutions" (2008) 21 Governance 165.

Brian W Schoeneman "The Scarlet L: Have Recent Developments in Lobbying Regulation Gone too Far?” (2011) 60 Cath U L Rev 505.

Cass R Sunstein "Political Equality and Unintended Consequences" (1994) 94 Colum L R 1390.

Conor McGrath "The Ideal Lobbyist: Personal Characteristics of Effective Lobbyists" (2006) 10 JCOM 67.

Conor McGrath "Towards a Lobbying Profession: Developing the Industry's Reputation, Education and Representation" (2005) 5 J Pub Aff 124.

David Lowerly and Virginia Gray “How some rules just don't matter: The regulation of lobbyists" (1997) 91 Pub Choice 139.

Dieter Grimm "Proportionality in Canadian and German Constitutional Jurisprudence" (2007) 57 Toronto L J 383.

Dorie Apollonio, Bruce E Cain, Lee Drutman "Access and Lobbying: Looking Beyond the Corruption Paradigm" (2008) 36 Hastings Const LQ 13.

Frank Bannister \& Regina Connolly "The Trouble with Transparency: A Critical Review of Openness in e-Government” (2011) 3 Policy Internet 121.

Harry H. Wellington “On Freedom of Expression” (1979) 88 Yale L J 1105.

Helen Kelly “The Hobbit Dispute” (2011) 36 NZJER 30.

Henry J Steiner "Political Participation as a Human Right" (1988) 1 Harv Hum Rts YB 77.

J Beecher "The Prudent Regulator: Politics, Independence, Ethics and the Public Interest” (2008) 29 Energy L J 577.

Jac C Heckelman "Explaining the Rain: The Rise and Fall of Nations after 25 Years" (2007) 74 Southern Econ J 18.

Jakob Svensson "Eight Questions about Corruption” (2005) 19 J Econ Perspect 19.

Jan Leighley "Group Membership and the Mobilization of Political Participation" (1996) 58 J Polit 447.

Jessica A Levinson "The Original Sin of Campaign Finance Law: Why Buckley $v$ Valeo is Wrong” (2013) 47 U Rich L Rev 881.

John Hogan, Gary Murphy and Raj Chari "Regulating the Influence Game in Australia" (2011) 57 Aust J Polit and Hist 102.

John Hogan, Raj Chari and Gary Murphy "Regulating Australia's Lobbyists: Coming Full Circle to Promote Democracy?” (2011) 11 J Pub Aff 35.

John M De Figueiredo "Lobbying and Information in Politics" (2002) 4 BAP 125. 
Karsten Ronit and Volker Schneidher "The Strange Case of Regulating Lobbying in Germany" (1998) 51 Parl Aff 559.

Kate Wilkinson "One Law to Rule Them All” (A. F. Tyson "A Synopsis of the "Hobbit Dispute" (2011) 36 NZJER 34.

Kim Doran "A Lobbyist's Observations on the Lobbying Act" (2010) 33 Canadian Parl Rev 24.

Liam Williams "Civil Death and Penal Populism in New Zealand" (2012) 20 Waikato L Rev 111.

Margaret Wilson "Constitutional Implications of 'The Hobbit' Legislation" (2011) 36 NZJER 90.

Mark Evans "Beyond the Integrity Paradox: towards 'good enough' governance?" (2012) 33 Policy Stud J 97.

Martin Doornbos "'Good Governance': The Rise and Decline of a Policy Metaphor?" (2001) 37 J Dev Stud 93.

Meredith A Capps "Gouging the Government: Why a Federal Contingency Fee Lobbying Prohibition is Consistent with First Amendment Freedoms" (2005) 58 Vand L Rev 1885.

Matthew S R Palmer "What is New Zealand's constitution and who interprets it? Constitutional realism and the importance of public office-holders" (2006) 14 Pub L Rev 133.

Michael Pinto-Duschinsky "Financing Politics: A Global View" (2002) 13 J Democr 69.

Michael Rush "The Canadian Experience: The Lobbyists Registration Act" (1998) 51 Parl Aff 516.

Nubia Evertson "Political Corruption and Electoral Funding: A Cross-National Analysis" (2013) 21 International Crim Justice Rev 75.

Paul Flannery "Lobbying Regulation in the EU: A Comparison with the USA \& Canada" (2010) 20 Soc Polit Rev 70.

Richard L Hall and Alan V Deardorff "Lobbying as Legislative Subsidy" (2006) 100 APSR 69.

Richard L Hasen "Lobbying, Rent-Seeking, and the Constitution" (2012) 64 Stan L R 191.

Robert H Mundheim "Conflict of Interest and the Former Government Employee: Rethinking the Revolving Door" (1981) 14 Creigh L R 707.

Santiago A Canton "The Role of the OAS Special Rapporteur for Freedom of Expression in Promoting Democracy in the Americas" (2001) 56 U Miami L Rev 307.

Stanley Ingber “The Marketplace of Ideas: A Legitimizing Myth” [1984] Duke L J 1. 
Stephen Barley "Corporations, Democracy and the Public Good" (2007) 16 J Manage Inq 201.

Steven A Browne "The Constitutionality of Lobby Reform: Implicating Associational Privacy and the Right to Petition the Government" (1995) 4 Wm \& Mary Bill Rts J 717.

Sujit Choudhry "So what is the Real Legacy of Oakes? Two Decades of Proportionality Analysis under the Canadian Charter's Section 1" (2006) 34 Sup Ct L R 501.

Thomas I Emerson "Freedom of Association and Freedom of Expression" (1964) 74(1) Yale L J 1.

Timothy Besley and Stephen Coate "Lobbying and Welfare in a Representative Democracy" (2001) 68 Rev Econ Stud 67.

Ved P Nanda “The 'Good Governance' Concept Revisited” (2006) 603 Ann Am Acad Polit Soc Sci 269.

Veerle Van Deoveren "Rethinking Good Governance” (2011) 13 Pub Integ 301.

Vincent R Johnson "Regulating Lobbyists: Law, Ethics, and Public Policy" (2006) 16 Cornell JL \& Pub Pol'y 1.

Virginia Gray and David Lowerly "State Lobbying Regulations and Their Enforcement: Implications for the Diversity of Interest Communities" (1998) 30 State Local Gov Rev 78.

W Scott Thrulow "New Obligations of MPs Under the Lobbying Act" (2010) 33 Canadian Parl Rev 46.

W Scott Thurlow "Some Observations on the State of Lobbying in Canada" (2010) Canadian Parl Rev 43.

William C Mitchell \& Michael C Munger "Economic Models of Interest Groups: An Introductory Survey" (1991) 35 AJPS 512.

William V Luneburg "Anonymity and Its Dubious Relevance to the Constitutionality of Lobbying Disclosure Legislation” 19 Stanford L Pol'y Rev 69.

William V Luneburg and Thomas M Susman "Lobbying Disclosure: A Recipe for Reform" (2006) 33 J Legis 32.

\section{Conference papers}

Agnes Callamard "Freedom of Expression and Advocacy of Religious Hatred that Constitutes Incitement to Discrimination, Hostility or Violence, No 2" (paper presented at the Expert Meeting on the Links Between Articles 19 and 20 of the ICCPR, Geneva, 2 October 2008).

Bernard Walker and Rupert Tipples "Voiceless Actors: The Hobbit Affair and the Future of Unions" (paper presented at Voices at Work Australasian Meeting, Melborne, 21 July 2012). 
Clive S Thomas and Ronald J Hrebenar "The Regulation of Interest Groups and Lobbying in the Fifty States: Some Preliminary Findings" (paper presented at the Annual Meeting of the Midwest Political Science Association, Chicago, Illinois, 18 April 1991).

D Pinard "Charter and Context: The facts for which we need evidence, and the mysterious other ones" (paper presented Osgoode Hall Law School Constitutional Conference, Toronto, 6 April 2001).

D Pinard "Uncertainty and Risks: Evidence in Constitutional Litigation" (paper presented at Annual Convention of the Canadian Institute for the Administration of Justice, Victoria BC, October 2000).

David Lindsey "A Brief History of Conscience Voting in New Zealand" (paper presented at the Australasian Study of Parliament Conference, Adelaide, 23 August 2007).

Geoffrey Cupit "When Does Justice Require Impartiality?" (paper presented to Political Studies Association Annual Conference, London, 10 April 2000).

James H Read "Is Power Zero-Sum or Variable-Sum? Old Arguments and New Beginnings" (paper presented to the Annual American Political Science Association, California, 2 September 2011).

Justice Susan Glazebrook "The New Zealand Bill of Rights Act 1990: its operation and effectiveness" (paper presented at the South Australian State Legal Convention, Adelaide, 23 July 2004).

Magnus Ohman "Global Trends in the Regulation of Political Finance" (paper presented to IPSA-ECPR Joint Conference, University of Sao Paulo, Brazil, 16 February 2011).

Marjorie Jerrard "The Collegium Fullonum, Collegium Centonarium, and CATU: Ancient Collegia and Modern Trade Unions - A Comparison of the Roles of Industrial Organisations in their Respective Societies" (paper presented at the Association of Industrial Relations Academics of Australia and New Zealand Conference, Wellington, 1998).

Pierre-Marc Daingneault "Transparency and Accountability: Solutions for Rebuilding Citizens' Trust in Public Institution? An Exploratory Study" (paper presented at the $20^{\text {th }}$ International Political Science Association World Congress, Fukuoka, 9-13 July 2006).

Pippa Norris "Democratic Phoenix: Agencies, Repertoires and Targets of Political Activism" (paper presented at the Annual American Political Science Association, Boston, 29 August 2002).

Sadhir Kumar "Study of Freedom of Information Act, US and Right to Information Act, India" (paper presented at the $40^{\text {th }}$ Annual Indian Association for American Studies, Coimbatore, 11 August 2010).

J Newspaper and magazine articles 
"Academic slams 'Hobbit Law' bid" The New Zealand Herald (A5, Auckland, 25 October 2010)

"Blinding the Waste Watchers" Gainesville Sun (Florida, 28 March 1995) at 10A.

"Editorial: Undue Influence" The New Zealand Listener (online ed, Auckland, 28 November 2013).

"Hobbit law passes, but not everybody on board" National Business Review (online ed, Auckland, 29 October 2010)

"Lobbying Scandal Q\&A: What it all means" The Telegraph (online ed, London, 01 June 2013).

“Maori Party don't know who offered \$250,000" The New Zealand Herald (online ed, Auckland, 29 September 2006).

"Winston Peters' Statement" The New Zealand Herald (online ed, Auckland, 25 July 2008)

"SkyCity deal unveiled: \$402m centre, 230 more pokies" The New Zealand Herald (online ed, Auckland, 13 May 2013).

"The MEP lobbying scandal is worse than anything at Westminster, but it will be largely ignored" The Telegraph (online ed, London, 20 March 2011).

"Timeline: The NZ First donations saga" The New Zealand Herald (online ed, Auckland, 23 September 2008).

Adam Bennett "Watchdog in Crisis, MPs Told" The New Zealand Herald (online ed, Auckland, 16 February 2012).

Adam Bennett and John Armstrong " $\$ 350 \mathrm{~m}$ SkyCity casino deal to be signed off" The New Zealand Herald (online ed, Auckland, 13 May 2013).

Adam Bennett, David Fisher "Select Treatment for SkyCity won't stop deal" The New Zealand Herald (online ed, Auckland, 20 February 2013).

Bernard Orsman "Super City Elections 2013: Mayor accused of pokies u-turn" The New Zealand Herald (online ed, Auckland, 2 October 2013).

Bradley Smith "Why Campaign Finance Reform Never Works" Wall Street Journal (A19, New York, 19 March 1997).

Caroline Lucas "Influence on MPs must be exposed and regulated" The Guardian (online ed, London, 22 July 2013).

Chris Keall "WikiLeaks cables: US govt pressured NZ over internet file sharing law" National Business Review (online ed, Auckland, 2 May 2011).

Claire Newell and Holly Watt "Patrick Mercer MP resigns over lobbying scandal" The Telegraph (online ed, London, 31 May 2013).

Claire Trevett "Local elections 2013: Low turnout spurs look at vote system" The New Zealand Herald (online ed, Auckland, 14 October 2013). 
Claire Trevett "MPs lapped up RWC tickets from corporates" The New Zealand Herald (online ed, Auckland, 24 May 2012).

Claire Trevett "Sparks fly in 'Hobbit Law' debate" The New Zealand Herald (online ed, Auckland, 29 October 2010).

David Fisher "SkyCity Wooed Govt after Court Failures" The New Zealand Herald (online ed, Auckland, 18 April 2012).

David Segal "Main Street America Has Advocates Aplenty: On the Hill, Lobbyists for All” Washington Post, (A1, Washington DC, 10 July 1995).

Gareth Richards "Lifting the Lid on Lobbying" NZLawyer Magazine (online ed, Auckland, 1 June 2012).

Issac Davison "MPs decide law to restrict lobbyists unnecessary in 'village' NZ" The New Zealand Herald (online ed, Auckland, 24 August 2013).

John Banigan “Lobbying Law” CMA Magazine (Toronto, October 2005).

John Carran "SkyCity Deal sends Wrong Message" The New Zealand Herald (online ed, Auckland, 08 May 2012).

Kate Chapman "Deal would be Transparent under Register" The Dominion Post (online ed, Wellington, 25 April 2012).

Louis Brandeis "What Publicity Can Do" Harpers Weekly (New York, 29 November 1913).

Mai Chen "SkyCity ruckus shows why lobbying bill needed" The New Zealand Herald (online ed, Auckland, 26 April 2012).

Matt Nippert “A license to print money?" The Dominion Post (online ed, Wellington, 27 July 2013).

Nikki Pender and Pam McMillan "SOP sinks mining protestors" Lawtalk (online ed, Wellington, 26 April 2013).

Patrick Gower "SFO head says MPs were being mislead" The New Zealand Herald (online ed, Auckland, 23 September 2008).

Sue Kedgley "Let's prevent our own lobbying scandal" The New Zealand Herald (online ed, Auckland, 27 June 2013).

K Press releases

Green Party "Govt abuses urgency to extend Anadarko Amendment" (press release, 17 May 2013).

Greenpeace "Pants on fire - billboard questions Minister's contacts with oil company" (press release, 16 July 2013).

New Zealand Actors Equity "NZ Actors Equity responds to new Hobbit information" (press release, 27 April 2012). 
Peter Jackson "Statement regarding The Hobbit and claims by MEAA" (press release, 27 September 2010).

\section{Speeches and interviews}

Barack Obama, President of the United States "Ethics and Lobbying Reform" (Lobbying Reform Summit, Washington DC, 26 January 2006).

Interview with Jessie Sheidlower, Editor-at-Large Oxford English Dictionary (Liane Hansen, A Lobbyist by any other name, National Public Radio, 22 January 2006) transcript provided by National Public Radio (Washington).

Trevor Mallard, Hon "Lobbying and the government" (Four Winds Communication Seminar, Wellington, 25 November 2003).

\section{Electronic materials \\ $1 \quad$ Working papers}

Benjamin M Blau, Tyler J Brough, Diana W Thomas "Corporate Lobbying, Political Connections and the 2008 Troubled Asset Relief Program" (30 September 2011) Social Science Research Network <www.ssrn.com>.

David M Primo and Jeffrey Milyo "Campaign Finance Laws and Political Efficacy: Evidence from the States" (2006) EconPapers <econpapers.repec.org>.

Deniz Igan, Prachi Mishra and Thierry Tressel "A Fistful of Dollars: Lobbying and the Financial Crisis" (May 2011) The National Bureau of Economic Research <http://www.nber.org/papers/w17076>.

Jordi Blanes i Vidal, Mirko Draca and Christian Fons-Rosen "Revolving Door Lobbyists" (August 2010) Centre for Economic Performance <cep.lse.ac.uk>.

Nauro F Campos and Francesco Giovannoni "Lobbying, Corruption and Political Influence (September 2006) Econstor <www.econstor.eu>.

Revolving Door Working Group "A Matter of Trust: How the Revolving Door Undermines Public Confidence in Government" (October 2005) Revolving Door <www.revolvingdoor.info>.

Matthew D Hill, G W Kelly, G Brandon Lockhart and Robert A Van Ness "Determinants and Effects of Corporate Lobbying" (28 June 2013) Social Science Research Network <www.ssrn.com>.

Robert Morlino, Leah Rush and Derek Willis "Hired Guns - Initial Report" (15 May 2003) The Centre for Public Integrity <www.publicintegrity.org>

\section{$2 \quad$ Websites}

"Data, Analysis and Documentation: Federal Employment Reports" (2011) United States Office of Personnel Management <https://www.opm.gov/policy-dataoversight/data-analysis-documentation/federal-employment-reports/historicaltables/executive-branch-civilian-employment-since-1940/>. 
“'Lobbyists' September 28, 1987" (2005) United States Senate <http://www.senate.gov/legislative/common/briefing/Byrd_History_Lobbying.htm>.

"12-Month Lobbying Activity Search" (09 September 2013) Office of the Commissioner of Lobbying of Canada <https://oclcal.gc.ca/app/secure/orl//rrs/do/clntSmmrySrch>.

"About the Controller and Auditor-General" (16 September 2013) New Zealand Controller and Auditor-General <http://www.oag.govt.nz/about-us〉.

"About Us" (3 January 2012) Office of the Commissioner of Lobbying of Canada <https://ocl-cal.gc.ca/eic/site/012.nsf/eng/h_00004.html>.

"European poll shows considerable concern about EU ethics, transparency and lobbying" (31 January 2013) EU Citizens: Citizens in the European Union <http://www.eu-citizens.org/noticia10.php>.

"Fighting Corruption in the Public Sector: Lobbying" (June 2013) OECD <http://www.oecd.org/gov/ethics/lobbying.htm>.

"Fighting Corruption in the Public Sector" (2013) OECD: Better Policies for Better Lives <www.oecd.org/gov/ethics/lobbying>.

"General Elections 1853-2011 - Dates and Turnout" (9 September 2013) Electoral Commission <http://www.elections.org.nz/events/past-events/general-elections-18532011-dates-and-turnout $>$.

"Govt 'comfortable' with handling of Hobbit dispute" (26 February 2013) ONE News $<$ http://tvnz.co.nz/national-news/govt-comfortable-handling-hobbit-dispute$5354100>$.

"Govt lied about Hobbit dispute timeline - union" (27 February 2013) ONE News $<$ http://tvnz.co.nz/national-news/govt-lied-hobbit-dispute-timeline-union-5354648>.

"Lobbying Registration (LD-1DS) Sample Form" (December 2009) Office of the Clerk: United States House of Representatives <lobbyingdisclosure.house.gov>.

"Lobbying" (2013) Encyclopædia $\quad$ Britannica <http://www.britannica.com/EBchecked/topic/345407/lobbying>.

"Party votes and turnout by Electorate" (November 2011) Electoral Commission Statistics

<http://www.electionresults.govt.nz/electionresults_2011/e9/html/statistics.html>.

"Register of Promoters 2011 General Election and Referendum" (1 February 2013) New Zealand Electoral Commission <http://www.elections.org.nz/events/past-events0/2011-general-election/parties-candidates-and-promoters-2011-general-election-1>.

"Registration Requirements for Consultant Lobbyists" (1 July 2012) A Guide to Registration <https://ocl-cal.gc.ca/eic/site/012.nsf/eng/00485.html\#overview>.

"Story: Elections and Campaigns - Electoral Finance" (13 July 2012) Te Ara Encyclopaedia of New Zealand < http://www.teara.govt.nz/en/elections-andcampaigns/page-5>. 
"Submissions and Policy Positions" (January 2013) New Zealand Mental Health Organisation <http://www.mentalhealth.org.nz/page/1297-submissions-policypositions>.

"TARP Recipients Paid Out \$114 Million for Politicking Last Year" (4 February 2009) OpenSecrets: Centre for Responsive Politics <www.opensecrets.org/news/2009/02/tarp-recipients-paid-out-114-m.html>.

"The IPRA Code of Conduct" (2011) International Public Relations Association <http://www.ipra.org/about/ipra-codes>.

"The Lobbying Act" (15 February 2012) Office of the Commissioner of Lobbying of Canada < http://www.ocl-cal.gc.ca/eic/site/012.nsf/eng/h_00008.html>.

"The Register" (2012) United Kingdom Public Affairs Consultants <http://www.publicaffairscouncil.org.uk/>.

"The Registry of Lobbyists" (January 2012) Office of the Commissioner of Lobbying of Canada <http://ocl-cal.gc.ca/eic/site/012.nsf/eng/00442.html>.

"Values" (2010) New Zealand Parliamentary Commissioner for the Environment <http://www.pce.parliament.nz/about-us/>.

Daniel Kaufmann "Corruption and the Global Financial Crisis" (2009) Forbes < http://www.forbes.com/2009/01/27/corruption-financial-crisis-businesscorruption.html>.

Helen Kelly "The Hobbit Dispute" (12 April 2011) Scoop Independent News $<$ http://www.scoop.co.nz/stories/HL1104/S00081/helen-kelly-the-hobbitdispute.htm\#ftn>.

Jeffrey M Jones "Record 64\% Rate Honesty, Ethics of Members of Congress Low" (12 December 2011) Gallup Politics <http://www.gallup.com/poll/151460/recordrate-honesty-ethics-members-congress-low.aspx $>$.

Karen E Shepherd "A Significant Part of Duties ('The 20\% Rule')" (July 2009) Office of the Commissioner of Lobbying of Canada <https://oclcal.gc.ca/eic/site/012.nsf/eng/00115.html>.

Kevin List "Mallard Attacks National's Use of Trust Funds" (23 July 2005) Scoop: Independent News <http://www.scoop.co.nz/stories/HL0507/S00308.htm>

Government Reform Unit "Regulation of Lobbying Legislation - Policy Proposals" (Information Note to Parliament of Ireland, April 2013) Department of Public Expenditure and Reform <http://per.gov.ie/wp-content/uploads/Summary-PolicyProposals.pdf>.

Nic Christensen "Lobbying regulations cover "the tip not the iceberg" (18 March 2013) Mumbrella <http://mumbrella.com.au/lobbying-regulation-covers-just-the-tipnot-the-iceberg-145998>.

OECD "Accountability" (April, 2013) Glossary of Statistical Terms $<$ http://stats.oecd.org/glossary/detail.asp?ID=4757>. 
OECD "Transparency" (July, 2002) Glossary of Statistical Terms $<$ http://stats.oecd.org/glossary/detail.asp?ID=4474>.

Susan Schmidt, James V Grimaldi and R Jeffrey Smith "Investigating Abramoff Special Report" (2005) The Washington Post <http://www.washingtonpost.com/wpdyn/content/linkset/2005/06/22/LI2005062200936.html>.

Tracey Watkins "The Rise and Rise of Lobbyists" (June 2011) Stuff - Politics <http://www.stuff.co.nz/national/politics/5099703/The-rise-and-rise-of-lobbyists>.

N Miscellaneous

Email from Office of Hon Gerry Brownlee to Liam Williams regarding communications with lobbyists (8 August 2013) (Obtained under Official Information Act 1982 Request to Office of Hon Gerry Brownlee).

Letter from Cheryl Gwyn (Deputy Solicitor-General) to Helena Catt (Chief Executive of the Electoral Commission) regarding anonymous donations to political parties (25 January 2007). 